\title{
Remote-Site Power Generation Opportunities for Alaska
}

\author{
Topical Report \\ March 1997 \\ By
Michael L. Jones
}

RECEIVED

Allg 151997

OSTI

Work Performed Under Contract No.: DE-FC21-93MC30098

For

U.S. Department of Energy

Office of Fossil Energy

Morgantown Energy Technology Center

P.O. Box 880

Morgantown, West Virginia 26507-0880

DISTRHEUTON OF THIS DOCMENT IS IAIMITIR

By

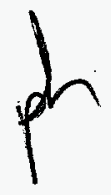

Energy and Environmental Research Center

University of North Dakota

P. O. Box 9018

Grand Forks, North Dakota 58202-9018 


\section{Disclaimer}

This report was prepared as an account of work sponsored by an agency of the United States Government. Neither the United States Government nor any agency thereof, nor any of their employees, makes any warranty, express or implied, or assumes any legal liability or responsibility for the accuracy, completeness, or usefulness of any information, apparatus, product, or process disclosed, or represents that its use would not infringe privately owned rights. Reference herein to any specific commercial product, process, or service by trade name, trademark, manufacturer, or otherwise does not necessarily constitute or imply its endorsement, recommendation, or favoring by the United States Government or any agency thereof. The views and opinions of authors expressed herein do not necessarily state or reflect those of the United States Government or any agency thereof. 


\section{DISCLAIMER}

Portions of this document may be illegible electronic image products. Images are produced from the best available original document. 


\section{DISCLAIMER}

This report was prepared as an account of work sponsored by an agency of the United States Government. Neither the United States Government, nor any agency thereof, nor any of their employees makes any warranty, express or implied, or assumes any legal liability or responsibility for the accuracy, completeness, or usefulness of any information, apparatus, product, or process disclosed or represents that its use would not infringe privately owned rights. Reference herein to any specific commercial product, process, or service by trade name, trademark, manufacturer, or otherwise does not necessarily constitute or imply its endorsement, recommendation, or favoring by the United States Government or any agency thereof. The views and opinions of authors expressed herein do not necessarily state or reflect those of the United States Government or any agency thereof.

\section{ACKNOWLEDGMENT}

This report was prepared with the support of the U.S. Department of Energy (DOE), Federal Energy Technology Center, Cooperative Agreement No. DE-FC21-93MC30098. However, any opinions, findings, conclusions, or recommendations expressed herein are those of the author(s) and do not necessarily reflect the views of the DOE.

\section{EERC DISCLAIMER}

LEGAL NOTICE This research report was prepared by the Energy \& Environmental Research Center (EERC), an agency of the University of North Dakota, as an account of work sponsored by U.S. Department of Energy. Because of the research nature of the work performed, neither the EERC nor any of its employees makes any warranty, express or implied, or assumes any legal liability or responsibility for the accuracy, completeness, or usefulness of any information, apparatus, product, or process disclosed, or represents that its use would not infringe privately owned rights. Reference herein to any specific commercial product, process, or service by trade name, trademark, manufacturer, or otherwise does not necessarily constitute or imply its endorsement or recommendation by the EERC. 


\section{TABLE OF CONTENTS}

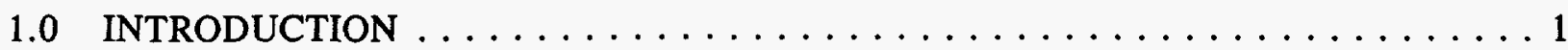

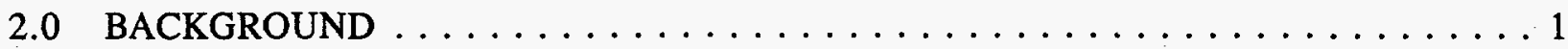

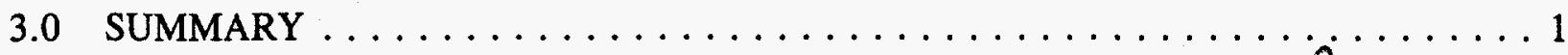

SMALL ALTERNATIVE POWER GENERATION WORKSHOP ... Aemoved. Appendix A GLOBAL MARKET ASSESSMENT OF COALBED METHANE, FLUIDIZED-BED COMBUSTION, AND COAL-FIRED DIESEL TECHNOLOGIES IN REMOTE

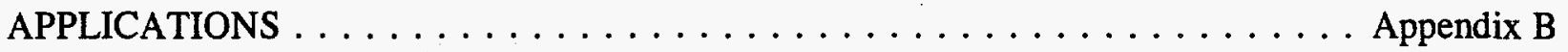




\section{REMOTE-SITE POWER GENERATION OPPORTUNITIES FOR ALASKA}

\subsection{INTRODUCTION}

The Energy \& Environmental Research Center (EERC) has been working with the Federal Energy Technology Center in Morgantown, West Virginia, to assess options for small, low-cost, environmental acceptable power generation for application in remote areas of Alaska.

\subsection{BACKGROUND}

The goal of this activity was to reduce the use of fuel in Alaskan villages by developing small, low-cost power generation applications. Because of the abundance of high-quality coal throughout Alaska, emphasis was placed on clean coal applications, but other energy sources, including geothermal, wind, hydro, and coalbed methane, were also considered. The use of indigenous energy sources would provide cheaper cleaner power, reduce the need for PCE (Power Cost Equalization program) subsidies, increase self-sufficiency, and retain hard currency in the state while at the same time creating jobs in the region. The introduction of economical, small power generation systems into Alaska by U.S. equipment suppliers and technology developers aided by the EERC would create the opportunities for these companies to learn how to engineer, package, transport, finance, and operate small systems in remote locations. All of this experience would put the U.S. developers and equipment supply companies in an excellent position to export similar types of small power systems to rural areas or developing countries. Thus activities in this task that relate to determining the generic suitability of these technologies for other countries can increase U.S. competitiveness and help U.S. companies sell these technologies in foreign countries, increasing the number of U.S. jobs.

\subsection{SUMMARY}

A number of Alaskan groups are partners with the EERC in this activity, including Doyen, Ltd., MTNT Village Corporation, McGrath Power and Light, Department of Community and Regional Affairs for the State of Alaska, Alaska Industrial Development and Export Authority, and the University of Alaska.

This topical report covers activities completed under U.S. Department of Energy (DOE) Contract No. DE-FC21-93MC30098. Completion of activities relating to remote-site power generation opportunities for Alaska are continuing under separate DOE funding.

The two deliverables for the portion of the work on remote power include the following:

- Small Alternative Power Workshop (topical report, Appendix A).

- Global Market Assessment of Coalbed Methane, Fluidized-Bed Combustion, and CoalFired Diesel Technologies in Remote Applications (Appendix B). 
APPENDIX A

SMALL ALTERNATIVE POWER GENERATION WORKSHOP

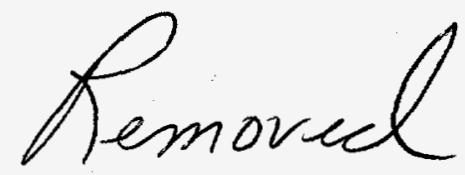




\section{TABLE OF CONTENTS}

LIST OF FIGURES $\ldots \ldots \ldots \ldots \ldots \ldots \ldots \ldots \ldots \ldots \ldots \ldots \ldots \ldots \ldots \ldots \ldots \ldots \ldots$ iii

LIST OF TABLES $\ldots \ldots \ldots \ldots \ldots \ldots \ldots \ldots \ldots \ldots \ldots \ldots \ldots \ldots \ldots \ldots \ldots \ldots \ldots$

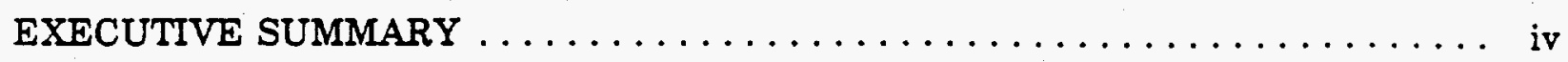

1.0 ALASKAN ENERGY SITUATION $\ldots \ldots \ldots \ldots \ldots \ldots \ldots \ldots \ldots \ldots \ldots$

2.0 ALASKA ENERGY STRATEGY $\ldots \ldots \ldots \ldots \ldots \ldots \ldots \ldots \ldots \ldots \ldots \ldots \ldots \ldots \ldots$

3.0 DCRAMETC CRADA GOALS $\ldots \ldots \ldots \ldots \ldots \ldots \ldots \ldots \ldots \ldots \ldots \ldots \ldots \ldots \ldots$

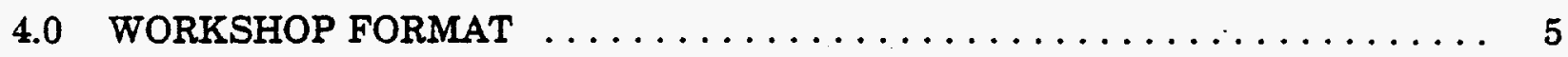

5.0 TECHNOLOGY TRANSFER IN ALASKA - OPPORTUNITIES AND

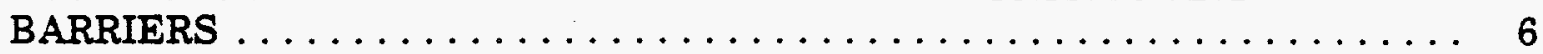

6.0 ALASKAN RESOURCES AND REGIONAL PROFILES $\ldots \ldots \ldots \ldots \ldots \ldots$

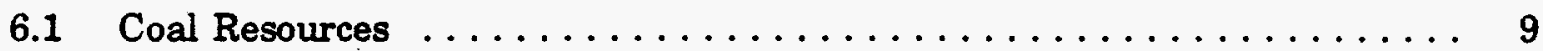

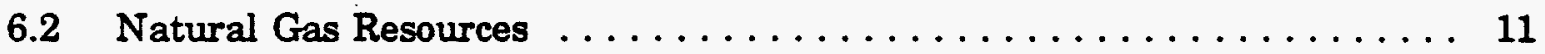

6.3 Renewable Energy Resources $\ldots \ldots \ldots \ldots \ldots \ldots \ldots \ldots \ldots \ldots \ldots$

6.4 Regional Power Profiles ....................... 14

6.4.1 Southeast Alaska Regional Profile $\ldots \ldots \ldots \ldots \ldots \ldots \ldots \ldots 15$

6.4.2 Southwest Alaska Regional Profile $\ldots \ldots \ldots \ldots \ldots \ldots \ldots \ldots 16$

6.4.3 Yukon Regional Profile ..................... 16

6.4.4 Arctic/Northwest Regional Profile ................ 16

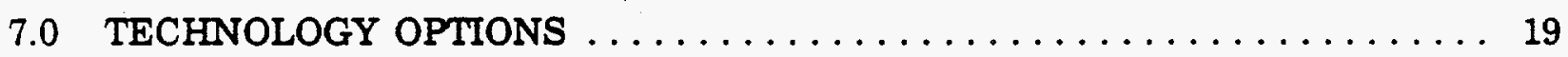

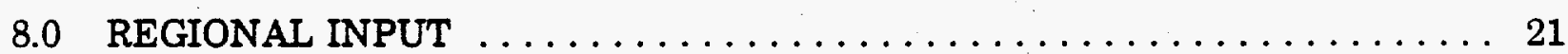

8.1 South East/South Central Region $\ldots \ldots \ldots \ldots \ldots \ldots \ldots \ldots \ldots, 22$

8.2 Arctic and Northwest $\ldots \ldots \ldots \ldots \ldots \ldots \ldots \ldots \ldots \ldots \ldots \ldots \ldots \ldots \ldots, 22$

8.3 Southwest $\ldots \ldots \ldots \ldots \ldots \ldots \ldots \ldots \ldots \ldots \ldots \ldots \ldots \ldots \ldots \ldots \ldots \ldots \ldots \ldots \ldots \ldots, 23$

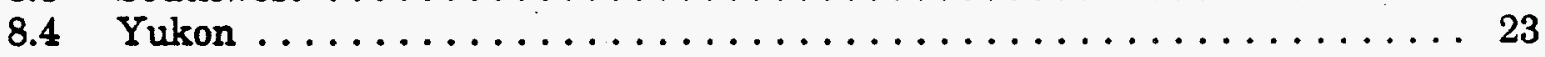

9.0 CONCLUSIONS AND RECOMMENDATIONS $\ldots \ldots \ldots \ldots \ldots \ldots \ldots \ldots$

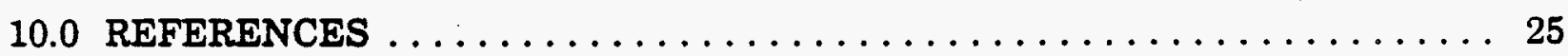

PRESIDENT CLINTON'S DIRECTIVE ON GOVERNMENT-TO.

GOVERNMENT RELATIONS WITH NATIVE AMERICAN TRIBAL

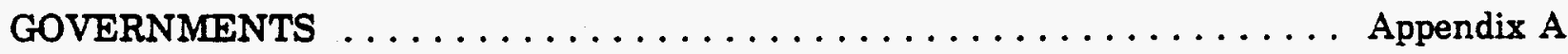

DCRA/METC CRADA SCOPE OF WORK $\ldots \ldots \ldots \ldots \ldots \ldots \ldots$ Appendix B

ALASKA ENERGY STRATEGY, APRIL $1994 \ldots \ldots \ldots \ldots \ldots \ldots$ Appendix C 
PRESENTATIONS FROM THE SMALL ALTERNATIVE POWER

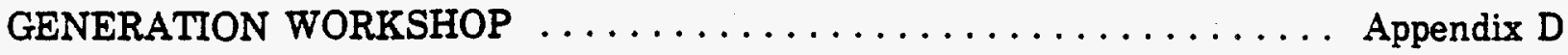
NOTES FROM BREAKOUT SESSIONS $\ldots \ldots \ldots \ldots \ldots \ldots \ldots \ldots$ Appendix E SMALL ALTERNATIVE POWER GENERATION WORKSHOP DEPARTMENT OF COMMUNITY AND REGIONAL AFFAIRS

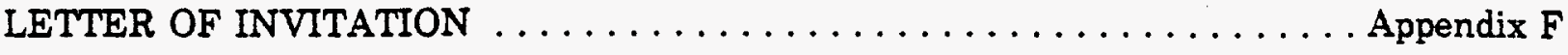

SMALL ALTERNATIVE POWER GENERATION WORKSHOP ATTENDEES LIST Appendix G STATISTICAL REPORT OF THE POWER COST EQUALIZATION PROGRAM - FISCAL YEAR 1992 Appendix H 


\section{LIST OF FIGURES}

1 Electric power costs in Alaska $\ldots \ldots \ldots \ldots \ldots \ldots \ldots \ldots \ldots \ldots \ldots \ldots$

2 Small Alternative Power Generation Workshop agenda ............. 7

3 Coal resources of Alaska $\ldots \ldots \ldots \ldots \ldots \ldots \ldots \ldots \ldots \ldots \ldots \ldots$

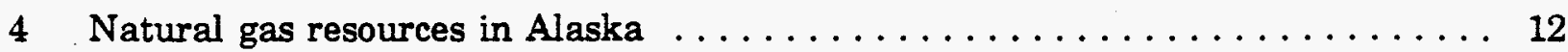

5 Alaskan locations rated for annual wind power at $30 \mathrm{~m}$ above ground $\ldots \ldots \ldots 14$

6 Comparison of residential energy consumption between Alaska and the lower 48

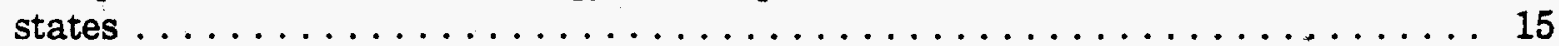

7 Regional breakout of Alaskan villages used for the workshop $\ldots \ldots \ldots \ldots \ldots 17$

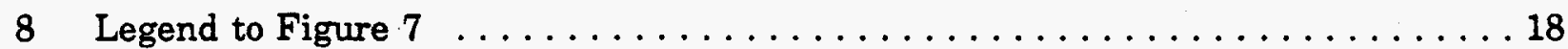

\section{LIST OF TABLES}

1 Comparison of Sulfur Content and Coal Ranking of Alaskan Coals to Those in the Lower 48 States of the USA . . . . . . . . . . . . . . . . . 10 


\section{EXECUTIVE SUMMARY}

The Small Alternative Power Generation Workshop was held in Anchorage, Alaska, as a first step in meeting the mission of the Alaskan Division of Energy, which is to assist in the development of safe, reliable, and efficient energy systems throughout Alaska that are financially viable and environmentally sound. This workshop was the first phase of a Cooperative Research and Development Agreement (CRADA) between the U.S.

Department of Energy Morgantown Energy Technology Center (U.S. DOE/METC) and the Alaskan Department of Community and Regional Affairs (DCRA). The objective of the CRADA is to apply advanced clean power-generating technologies being developed by industry in partnership with U.S. DOE/METC to the unique needs and requirements of the rural Alaskan communities. This will satisfy three distinct goals: 1) to make reasonably priced electric power available to remote villages that depend on high-cost oilfired diesel generators; 2) to demonstrate the capability and versatility of coal-fired or natural gas-fired emerging power generation systems; and 3) to act as a springboard for marketing these advanced technologies throughout Alaska and other parts of the world. Additional benefits of the work will be to reduce the environmental damage associated with the transportation and storage of diesel fuel, to conceive of means to diminish the problem of municipal waste and refuse disposal in Alaska, and possibly provide means to dispose of raw sewage in areas that do not have adequate municipal sewage systems.

The second phase of the CRADA will entail four feasibility studies, with the technology options and sites selected based on feedback from Alaskans during the workshops. These feasibility studies should lay the groundwork for the next logical step, full-scale demonstrations of those technologies determined to be economically and technically viable. Such a demonstration project will require interaction and support between industry and the federal, state, and local governments.

This workshop was a success; it established good three-way communication among government policymakers, suppliers of technology, and end users, the rural Alaskans. As a result of the interactive presentations and breakout discussion groups during the workshop, the needs of the Alaskans were heard, and a number of technology options were offered that could meet these needs. Participation by representatives from the villages in the decision-making process is crucial. This participation is emphasized in the President's April 29, 1994, Executive Directive on Government-to-Government Relations with Native American Tribal Governments and was stated as a goal of the state of Alaska by Commissioner Blatchford in his opening remarks to the workshop. The participants reacted positively to the interaction that was established through the format of the workshop, and the State of Alaska Division of Energy efforts to facilitate this interaction as host for the workshop were considered a success.

A number of concerns were identified by the local Alaskans as needing consideration regarding alternative power systems. Purchase of expensive diesel fuel results in a large share of local dollars flowing out of the community. These purchases do not produce many local jobs. The cost of transportation regulations and lack of economies of scale are the principal problems driving up the cost of fuel in Alaska. The current use of diesel fuel also presents environmental problems related to its transport and storage. It is estimated that \$200-400 million will be required to bring the existing diesel fuel storage systems into compliance with current state and federal regulations. Another major issue facing many Alaskan villages is waste disposal, including sewage, municipal solid wastes, and 
wood wastes. Other issues relating to infrastructure, or lack thereof, in Alaska were also identified as needing to be an integral part of the energy solution. Alternative power generation options are a partial solution to these broader problems. Inadequate infrastructure and other related issues are outside of the scope of this CRADA.

Alaskans identified a number of elements which are part of any necessary energy solution. These include the following:

- An integrated solution that addresses energy, heating, transportation, and waste disposal needs

- An emphasis placed on improving the health of community members

- Attention centered on the environment and identifying power systems that are environmentally friendly

- Power generation options that are more cost-effective than diesel generators

- The use of local resources to create more jobs and keep more dollars in the local economy

- Demonstration of technologies that can meet many or all of the above needs.

The single item that the Alaskans identified as most needed was demonstration of the alternative power generating options. Alaskans are tired of paper studies that do nothing to correct the current situation. These demonstrations would serve two purposes: 1) to begin the process of replacing diesel engines and 2), more importantly, to provide sites where potential users of new technologies could come for a firsthand look at technologies meeting the needs of rural Alaska and its unique conditions. It was stressed that site identification should be user-driven, based on existing information. It was anticipated that a number of technologies would be chosen for demonstration, since needs and resources differ between communities.

A number of technologies were presented at the workshop that appear to meet the demands of rural Alaska. Several systems were suggested that can use coal, biomass, and other refuse as fuel sources. These include fluid-bed combustors and multifuel stokers. Coal-fired diesels could capitalize on a coal-water fuel (CWF) demonstration plant planned in Alaska. The environmentally benign CWF will create an export market while providing a viable fuel for local Alaskan villages and other states such as Hawaii that use diesel power. Other systems, such as fuel cells, take advantage of the natural gas or coal bed methane that is abundant in many regions of Alaska. These systems provide cleaner, more user-friendly, and perhaps lower-cost energy options for the production of heat and electricity in Alaska. Hybrid systems of wind, photovoltaics, battery storage, and diesel generators also provide a technically feasible option, but are considerably more expensive than others. Rapid deployment of these technologies needs to be a priority in direct response to the Alaskans' strong requests for demonstrations rather than studies. 


\section{SMALL ALTERNATIVE POWER GENERATION WORKSHOP}

\subsection{ALASKAN ENERGY SITUATION}

In the over 165 remote rural villages in Alaska, the use of local fossil fuel supplies or renewable energy resources could greatly reduce the cost of electricity and space heating. Currently, diesel engine generators are the most numerous electrical generating systems. The cost of fuel oil for these generators ranges from a low of $\$ 0.73 /$ gal for large communities like Nome to $\$ 3.00 / \mathrm{gal}$ in small communities like Telida, largely because of transportation expense.

The high fuel costs result in extremely high electric power costs relative to the lower 48 states. These costs range between 10 cents/kilowatt hour $(\mathrm{kWh})$ and 100 cents/kWh as shown in Figure 1 (1). As Figure 1 shows, the cost of electricity in even the urban areas of Alaska averages 11 cents $\mathrm{kWh}$, almost double the 6.8 cents $/ \mathrm{kWh}$ average U.S. electricity price (1991 figure) (2).

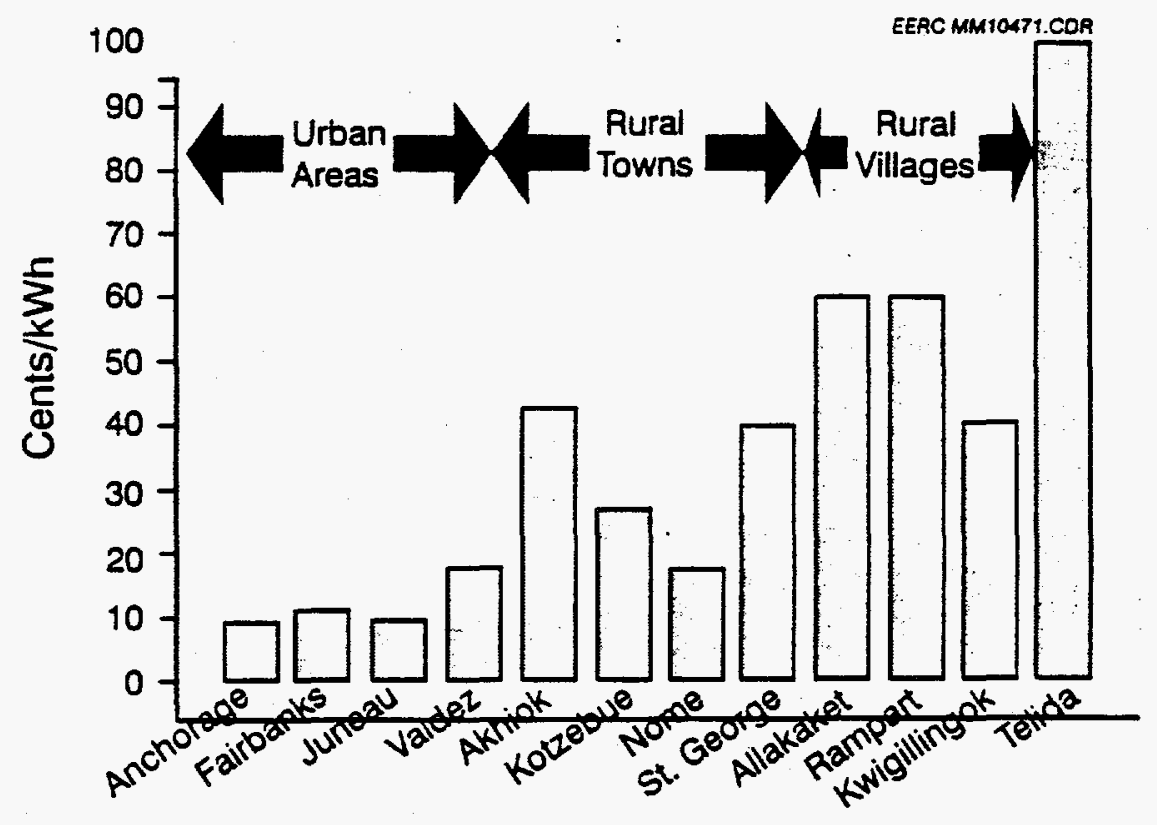

Figure 1. Electric power costs in Alaska. 
Much of the rural electricity generation is from diesel generators, but storage of large quantities of diesel fuel presents a problem in the harsh, unforgiving environment of Alaska. The state is faced with a monumental problem associated with fuel storage facilities. In 44 communities surveyed recently, 325 tank farms were identified. Over $98 \%$ of these facilities had significant violations of regulations or safety codes. This high level of noncompliance represents a major threat to public safety and the environment. It is estimated that between $\$ 200$ and $\$ 400$ million in repairs and new construction will be required to bring the bulk fuel tank farms in compliance with current federal and state regulations. This will cost an average of $\$ 1.5$ million per community (3). This cost does not include those associated with remediation of the environment where fuel oil and gasoline have leaked into the soil. The environmental remediation of these fuel oil leaks will run into the tens of millions of dollars.

The State of Alaska Division of Energy, Department of Community and Regional Affairs (DCRA), currently administers the Power Cost Equalization Program (PCE) which helps to defray the high cost of electricity in rural villages. In 1992, the state of Alaska subsidized electricity by an average of 15 cents $/ \mathrm{kWh}$, an average of $\$ 757$ per customer (1). These subsidies are tied to Alaska's oil revenues from the Trans-Alaska Pipeline, a revenue source that is shrinking. Therefore, interest is growing in Alaska for electrical power-generating systems that are not linked to the high cost of fuel oil and are not harmful to the environment. Coal-fired advanced power generation systems could prove to be a viable option to diesel-based power generation.

The high cost of importing fuel oil creates a significant burden to the residential homeowner. Diesel oil is used by most residents for heating. The cost of diesel fuel is often over $\$ 2.00 / \mathrm{gal}$ in remote areas. The high cost of fuel oil for space heating and cooking is even more staggering when put in the context of the average yearly household income for the native population in Alaska, only $\$ 14,267$ (4). Thus in many villages throughout Alaska, heating alone can consume $25 \%$ of a family's income.

The reduction of fuel costs associated with the use of indigenous, locally available fuels running modular, high-efficiency power generation systems would be extremely beneficial. Alaska is perceived as a pristine wilderness by most U.S. citizens. Therefore, the environmental burden imposed by any power generation system must be very low. Low environmental emissions are a necessary feature of the power generation technologies that are discussed in the following sections; thus they should be particularly acceptable in Alaska.

Results of any studies or demonstration projects that are applied to remote microgrid village sites in Alaska should have ready application to off-grid sites in other regions of the world, principally in the developing countries. Several papers explore this issue in greater detail than these proceedings are able to cover $(5,6)$.

\subsection{ALASKA ENERGY STRATEGY}

The Alaska Energy Authority was created by the Alaskan legislature in 1976 and charged with the following mission: to promote, develop, and advance the general prosperity and economic welfare of the people of Alaska by providing a means of constructing, acquiring, financing, and operating power projects and facilities that tap 
Alaska's natural resources to produce electricity and heat. Since 1976, the Energy Authority has helped provide reliable, on-line electricity to more than 200 communities, representing more than three-quarters of the state's population.

Several years ago, once the large power generating projects were completed, the Alaska Energy Authority directed its attention to rural communities. The coordination of the new rural effort, along with the development of alternative and applied technologies, represented a fundamental shift in the direction for the Authority. With the winding down of multimillion dollar projects and no major construction projects on the horizon, many felt it was time to reorganize, redefine, and redirect the state's energy policy.

In April of 1993, legislation was signed by Governor Walter J. Hickel that created a new Division of Energy within the State Department of Community and Regional Affairs (DCRA). Oversight responsibility for the Energy Authority-owned projects was transferred to the Alaska Industrial Development and Export Authority. The new division takes on the rural programs and planning responsibilities. The mission for this group, according to the legislation, is to assist in the development of energy-efficient systems throughout Alaska that are financially viable and environmentally sound.

The elements of DCRA's strategy to accomplish its mission include the following:

- Promoting ways to provide power at lower costs with increased safety and reliability

- Replacing diesel generation wherever possible with local adternatives such as coal, natural gas, biomass, hydroelectric, and wind

- Increasing existing system efficiency by utilizing waste heat and upgrading deficient distribution systems.

- Encouraging local utilities to develop professional management

The workshop was a part of this overall strategy. A copy of the Alaskan Energy Strategy is presented as Appendix C.

\subsection{DCRAMMTC CRADA GOALS}

The State of Alaska Division of Energy DCRA and the U.S. Department of Energy Morgantown Energy Technology Center (U.S. DOE/METC) have entered into a Cooperative Research and Development Agreement (CRADA) with the overall mission to advise and assist Alaskan energy managers and energy users on the attributes of various fossil fuel technologies. Notable in this mission is the absence of any dictation of solutions to Alaskans. This plan makes the basic philosophical assumption that Alaskan energy managers and corporate energy users are in the position to decide which energy option is best for their unique set of circumstances. The advice and assistance to Alaskan energy managers and energy users will focus on the technical and economic aspects of fossil fuel supply and utilization systems. Hybrid or renewable energy systems will also be encouraged. Full-scale pilot projects will be developed and managed, leading to 
commercial applications of the selected technologies in Alaska, other applications within the U.S. borders, and applications in developing countries.

The Alaskans have their funds at stake through the CRADA, which represents a minimum 50/50 cost-share program both in the base CRADA agreement and through the University of North Dakota Energy \& Environmental Research Center (EERC) joint venture program for remote Alaskan villages. The Alaskan Department of Community and Regional Affairs is the direct CRADA partner, while the Alaska Industrial Development and Export Authority, an independent corporation of the state government and private firms, have cofunded the EERC support efforts.

The U.S. DOE is meeting the intent of President Clinton's April 29, 1994, Executive Order using this workshop and other communication processes to make sure that native groups are fully aware of and participating in the investigation of small power systems. For the text of the President's Executive Order, see Appendix A.

The objective of this CRADA is to apply advanced clean power-generating technologies being developed by METC to the unique needs and requirements of the Alaskan Division of Energy. This will satisfy three distinct goals:

- To make reasonably priced electric power available to remote villages that depend on high-cost oil-fired diesel generators

- To demonstrate the capability and versatility of coal-fired and natural gas-fired emerging power generation systems

- To act as a springboard for marketing these advanced technologies throughout Alaska and other parts of the world

Additional benefits of this work will be to reduce the environmental damage associated with the transportation and storage of diesel, to conceive means of diminishing the problem of municipal waste and refuse disposal in Alaska, and possibly provide means of disposal of raw sewage in areas that do not have adequate municipal sewage systems.

The objectives of this CRADA will be accomplished in two phases. During the first phase, the Alaskan Division of Energy will host workshops on advanced power systems for use in rural locations. METC will supply information and contact vendors of advanced power systems (i.e., coal-fired diesel and indirect-fired gas turbines, atmospheric and pressurized fluidized-bed combustion (FBC), gasification, hot-gas cleanup, novel and conventional natural gas). METC will encourage and promote additional attendance and input to the workshops by its contractors and other knowledgeable parties. Initially, an international workshop will be held in Anchorage, Alaska. The workshop, held on May 17 and 18, 1994, is the subject of this report. Phase II will involve determining the feasibility of using advanced alternative power-generating options for remote applications. The next logical step is the full demonstration of those technologies determined to be technically and economically feasible. A copy of this CRADA is presented as Appendix B. 


\subsection{WORKSHOP FORMAT}

The overall objective of this workshop was to identify and select several sites in Alaska to be used as models by the Division of Energy and U.S. DOE/METC for the conceptual design of low-cost power plants utilizing local indigenous fuel sources, primarily, coal, wood, peat, municipal solid waste (MSW), sewage, and other biomass. To meet this overall objective, several specific objectives for the workshop were established:

- Inform decision makers in Alaska of near-term clean coal technologies that are suitable for rural power applications.

- Get feedback on the technologies that will be chosen for site-specific feasibility analyses.

- Provide exposure for equipment vendors and system packages to both the Alaskan and international small power markets.

The targets of the workshop were power system managers and village leaders. Options were presented for the use of local fuel sources and renewable energy sources as alternatives to diesel fuel for electric power generation.

To acquaint potential suppliers of small power systems with the unique environmental and business climates that exist in Alaska, a preworkshop was held at METC. Information regarding the nature of the energy supply issues in rural Alaska, including coal and solid fuel resource availability, were discussed by representatives from

DCRA. Feedback from this preworkshop indicated that the potential technology suppliers needed more information about the types of energy resources, energy consumption, and economic aspects of Alaska to best define the energy systems applicable to Alaska. In addition, it was suggested that the next steps should be more focused on the use of a general category of indigenous fuel resource so that the suppliers could concentrate efforts on the technologies that can best utilize those resources. As a result, DCRA and U.S. U.S. DOE agreed to focus the next steps on regionally available solid fuels in Alaska.

The format of the workshop held in Anchorage was designed to achieve substantial input from Alaska's rural communities. In all stages of the CRADA, METC and DCRA have continually tried to serve as facilitators, introducing new technologies while allowing Alaskans the freedom to make their own determination of what technologies would best meet their needs. The first session of the workshop presented the state's energy policy and regional profiles, including available fuel resources and load characteristics. Information provided during these sessions is included in Sections 1.0, 2.0, and 5.0. Technology options and commercial vendor presentations were covered in later sessions. Highlights from these presentations are given in section 6.0, Technology Options. Each session was arranged to allow extended time for questions and answers. These sessions were followed by breakout groups. The groups were broken into four main regions representing the Southcentral/Southeast, Arctic/Northwest, Southwest, and Yukon. The groups reconvened after the breakout sessions and their discussions were summarized. These breakout groups were an important part of the overall workshop, since they provided Alaskans an opportunity to interject their input into the planning of the next phases of this CRADA. Luncheon speakers provided insights on the 
opportunities and barriers of technology transfer in Alaska. Their comments are highlighted in Section 4.0.

A poster session was also held in conjunction with the workshop to provide the opportunity for other companies to present technologies applicable to the energy situation.

There were 112 attendees at the workshop representing a wide variety of groups. Twenty-five attendees were representatives from native Alaskan villages, boroughs, corporations, and utilities; 15 technology vendors; 10 representatives from the Alaskan Division of Energy; 5 Department of Energy officials; 15 developers and consultants, and 42 others, including representatives from Rural Alaska Power Association (RAPA), the Alaskan Village Electric Cooperative, Yukon, and Northwest Territories in Canada. A full listing of the attendees is given in Appendix G. The agenda for the workshop is provided in Figure 2.

\subsection{TECHNOLOGY TRANSFER IN ALASKA - OPPORTUNITIES AND BARRIERS}

An excellent overview of technology transfer in Alaska was presented by Drs. Ted Eschenbach and John Sibert in their luncheon talks. Highlights of these talks are presented here.

Alaska is an excellent test site for new energy-related technologies. The state has a very high energy cost, making it easier for new technologies to compete on an economic basis. Alaska has large quantities of indigenous resources that it desires to use to bolster the state's economy. Environmentally sound methods of dealing with a number of waste products are needed, providing an opportunity for innovative solutions. Additionally, alternative energy sources are being welcomed by both the private and public sectors in Alaska. Support from the Federal government is also available, provided by the 1992 Energy Policy Act. This CRADA between METC and DCRA is a good example of the federal, state, and local community partnerships. The Alaska Science and Technology Foundation also has an interest in funding demonstrations to further the use of Alaska's indigenous resources.

In approaching the Alaskan market, potential suppliers of technology need to be aware of and focus on the people of Alaska and their needs. The people who will purchase, build, operate, maintain and service, transport, and handle ash disposal for any new power systems in Alaska are different from the typical customer in the lower 48 states. The same group, a small utility for example, may be responsible for all aspects of the power system, or various groups could be responsible for each step in implementing these new technologies. The input provided by the Alaskans during this workshop provided viewpoints from the government, the Alaskan people, and the vendors. Any system installed in Alaska must ultimately meet the needs of the Alaskans.

To improve the Alaskan economy, electricity generation technologies must use indigenous resources to keep dollars in rural Alaska, rather than having them flow to the larger urban areas or out of state, as happens now with the purchase of diesel fuel. Currently, the state government has been heavily involved in ensuring electricity is supplied to all Alaskans through, various programs which are now in danger of being 
WORKSHOP WELCOME AND OPENING REMARKS

Alaska Energy Policy Direction Speaker: Commissioner Edgar Blatchford, Department of Community and Regional Affairs

Current Energy Projects to Achieve Energy Independence Speaker: Gary Cox, Division of Energy

Regional Profiles of Alaska Speaker: Dan Walsh, Mineral Industry Research Lab, University of Alaska Fairbanks

Technology Transfer in Rural Alaska Speaker: Professor Ted Eschenbach, School of Engineering, University of Alaska, Anchorage Technology Options for Rural Alaska Speaker: Donald Bonk, U.S. Department of Energy Morgantown Energy Technology Center, Morgantown, WV

\section{VENDOR PRESENTATIONS}

Cofiring Municipal Sold Waste Speaker: Michael DeLallo, Gilbert/Commonwealth, Reading, PA

Wind, Solar, Diesel, Battery Hybrids Speaker: Steve Drouilhet, National Renewable Energy Lab, Golden, CO

Low-Rank Coal-Water Fuel-Encoal and Rosebud Processes and Hot-Water Drying Speaker: Michael Mann, Energy \& Environmental Research Center, Grand Forks, ND

Coal-Fired Diesel Power Plants Speaker: John White, Cooper Energy Services (Cooper Bessemer), Anchorage, AK

Wind and Hydrogen Fuel Cells Speakers: Dr. Scott Hynek, Arthur D. Little, and Dr. William Lueckel, International Fuel Cells

Externally Fired Combined Cycle Speaker: William "Cary" Smith, U.S. Department of Energy Morgantown Energy Technology Center, Morgantown, WV

Small Atmospheric Fluidized.Bed Combustor Speaker: Rodney Webner, The Will-Burt Company, Orrville, $\mathrm{OH}$

Small Atmospheric Fluidized-Bed Combustors Speaker: Chuck McMenamy, DONLEE Technologies, ,York, PA

Wood-Fired Cogeneration Plants Speaker: Peter Bloomfield, Bloomfield and Associates, Concord, NH

Barriers and Opportunities in Rural Alternative Energy Lunch Speaker: John Sibert, Alaska Science \& Technology Foundation

Poster Session

\section{BREAKOUT GROUPS}

Summarize Breakout Groups Randy Dellefield, Morgantown Energy Technology Center, Morgantown, WV

Figure 2. Small Alternative Power Generation Workshop agenda.

reduced or eliminated. Because of the lack of financial resources, any potential technologies must be successfully demonstrated to be economically sound. The state government does not have the resources to provide a total fix for the current energy problem. The most attractive technologies will be those developed in Alaska, but having applications for sale elsewhere in the world. 
Power systems for the state of Alaska must meet numerous objectives. Both low capital and operating costs are desirable; however, when a trade-off is required, the levelized cost of electricity and/or heat should be the deciding factor. Any system being used in Alaska must also have extremely high reliability. Any outage is very costly and potentially fatal in Alaska because of the climate, transportation, and logistics.

Fuel flexibility is important for Alaska. Power systems that can handle a variety of fuels are most desirable. This will allow the user to burn the most economical fuel. While fuels flexibility is of major interest, environmental performance must not be overlooked. To preserve the environmental quality of Alaska, environmental impact must be low. Gaseous emissions, particulate emissions, and solid wastes must be minimized. Included in the operability objectives is the need to minimize the risk of system failure as a result of mechanical or operator error.

The small size of Alaskan villages restricts their economic options. Economic performance is limited not only by small size, but by limits on local control over resources and remoteness. Power systems must be implemented that reduce the need for importing fuel. The current power generation and heating systems that utilize diesel fuel result in dollars being sent out of the user locality. Preserving local dollars is a form of economic development by import substitution. Systems linked to local and in-state spending are the most attractive. Likewise, systems that will promote local employment and skill development will provide the most benefits to the remote villages in Alaska.

Along with these opportunities and objectives come certain constraints that are somewhat unique to Alaska. A critical question for someone financing a new system is ensuring that electricity is paid for. Most villages are cash poor. Concepts where electricity is prepaid and/or backed with a guarantee from the state may need to be considered. Alaska is geologically separated from most of the providers of technologies, making travel for sales and technical service more costly and time consuming. As a consequence of its geography and remoteness, Alaska has advanced the development of electronic communication systems in the United States. As the "information highway" continues to expand, one can easily envision users and vendors being able to use communication technology to improve sales and service, thus decreasing the risks associated with remoteness and long periods of rough weather.

An important constraint is the small size and the remoteness of the villages coupled with the severe climate. In essence, no inherent safety net is available to handle system failure. The small size and remoteness also present a constraint in terms of economies of scale. Because a power system needs to be scaled down to meet the size of the remote villages, costs per unit power are likely to increase, but need to be reasonably competitive with diesel. This may be possible only if an environmental penalty is applied to diesel fuel, or local fuel is given some form of preference.

Additional constraints include a lack of capital and limited local technical knowledge of advanced energy systems. Also, governmental restrictions will apply, including regulatory compliance to existing regulations, the uncertainty of future environmental regulations, and the rate structure that will be proposed by the state.

These objectives and constraints should serve as guidelines to someone trying to enter the Alaskan market. The opportunities in Alaska and other international markets 
are real. The market potential for small systems serving remote power sites is substantial, and technology able to meet the objective of the Alaskans and overcome the associated constraints should be able to capture a large share of this market.

\subsection{ALASKAN RESOURCES AND REGIONAL PROFILES}

\subsection{Coal Resources}

Mr. Dan Walsh of the Mineral Industry Research Laboratory at the University of Fairbanks provided an overview of the regional profiles and resources in Alaska. His presentation is included in Appendix D. His evaluation of available resources is included in this section.

Alaska has vast untapped coal resources as shown in Figure 3 (7). Alaska's onshore low-sulfur coal resources are thought to be in the range of 5.6 trillion tons. There are 50 coalfields in Alaska, with the bulk of the resources in six major fields or regions: Nenana, Cook Inlet-Susitna, Matanuska, Chignik-Herendeen Bay, North Slope, and Bering River. In terms of reserves that are proven and measured, the quantity is a very substantial 2.4 billion tons (8).

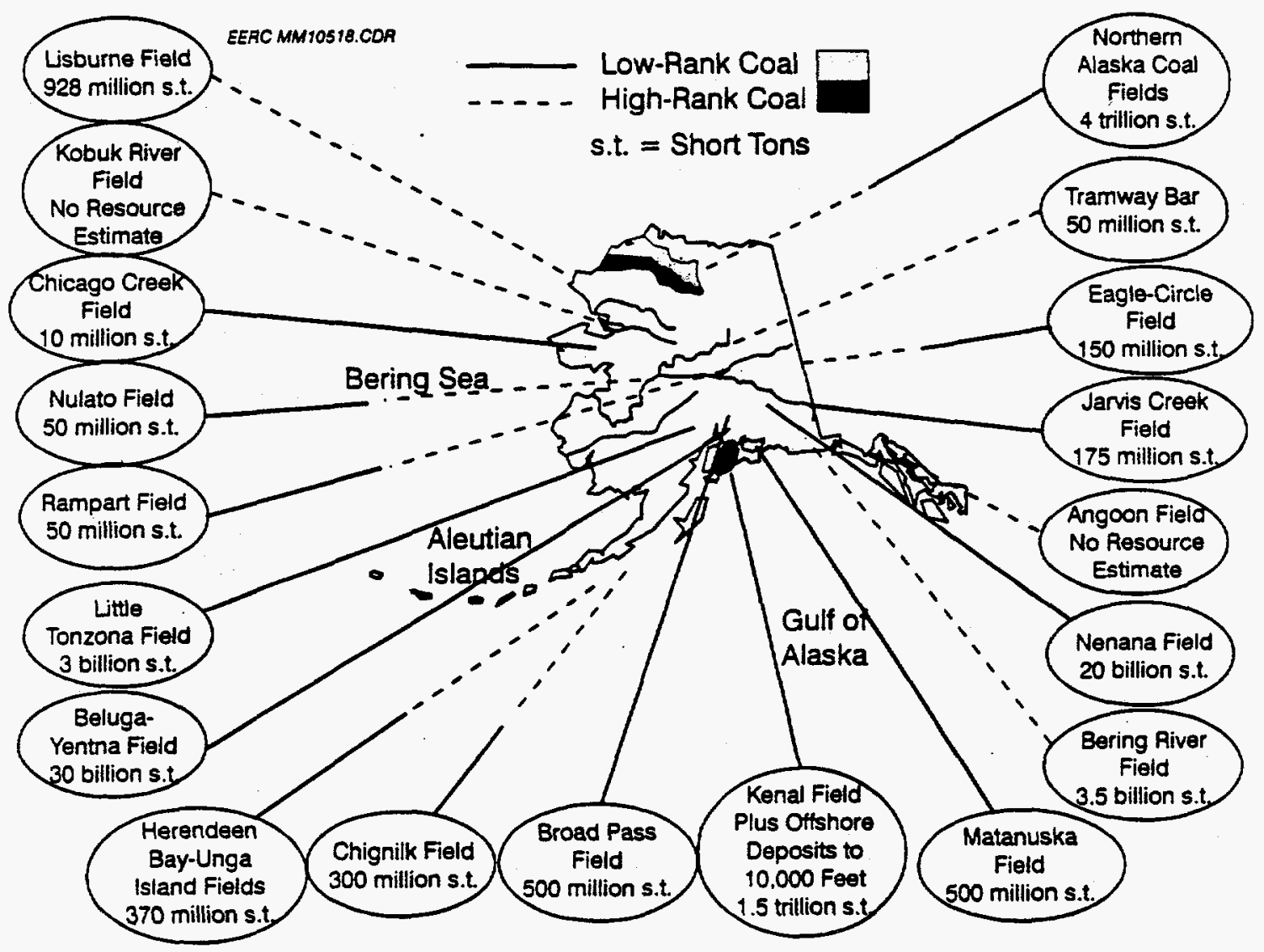

Figure 3. Coal resources of Alaska. 
Currently, Alaska has one operating coal mine, the Usibelli mine in central Alaska. This one mine produces coal for some of the larger coal users in Alaska and for export to Korea. Roughly one-half is used in-state, and the other half is exported to Foreign Energy Power Company's Honan Power Station. The potential exists for the coal industry to grow from its 1.5 million tons of coal per year (tpy) current output at Usibelli to over 14 million tpy within the next decade.

High transportation costs of rail shipping on the state-owned railway to the port of Seward, loading charges, and oceanic shipping costs result in a $\$ 4 /$ ton cost premium on coal. The continued ability to export this coal is tied greatly to the cost of transportation, which accounts for two-thirds of the delivered price of the exported coal.

Even though Alaska has large resources of low-sulfur coal, these resources have not been developed because of remote locations, little infrastructure, and inhospitable climate (9). The coals located close to near-year-round open tidewaters are low-rank coals. Alaska is close to two of the largest steam coal importers, Japan and Korea. Nominal 14 million tons/yr of potential coal production would create 1000 new jobs and add about $\$ 200$ million yearly to the gross state product (10).

A principal advantage of Alaskan coals is their low sulfur content, making them one of the cleanest coals in the United States. Table 1 shows that Alaskan coals have only $40 \%$ of the sulfur contained in well-accepted low-sulfur western U.S. coals. Compared to Appalachian region coals, Alaskan coals contain less than $20 \%$ of the sulfur.

The Division of Energy is working on a number of projects to enhance Alaska's instate coal capability. For example, the Division has contracted with the Energy and Environmental Research Corporation in Orrville, Ohio, to identify and prototype the installation of $250-\mathrm{kW}$ to $2-\mathrm{MW}$ coal-fired cogeneration facilities capable of utilizing local coal resources. The Division has also entered into an agreement with Doyon Limited that will see the state of Alaska participate in the conceptual design of an advanced technology coal-fired fluid bed combustion cogeneration plant that would utilize Little Tonzona coal. As will be discussed later, the potential exists for a similar project at Tok, AK with Alaska Power and Light. They will stimulate the use of coal-fired systems in Alaska.

TABLE 1

Comparison of Sulfur Content and Coal Ranking of Alaskan Coals to Those in the Lower 48 States of the USA

\begin{tabular}{lcc}
\hline Coal & Average Sulfur Content & Average Coal Rank \\
\hline Alaska & 0.34 percent & Subbituminous B \\
Appalachian Region & 2.3 percent & $\begin{array}{c}\text { High-Volatile A, } \\
\text { Bituminous }\end{array}$ \\
$\begin{array}{l}\text { Rocky Mountain/Northern Great } \\
\text { Plains Region }\end{array}$ & 0.86 percent & Subbituminous B \\
\hline
\end{tabular}


The Division is also involved in a project that could help open up the vast Beluga coal deposits on the west side of Cook Inlet, the Alaska Low-Rank-Coal-Water Fuel project. This project involves many organizations from Alaska and the lower 48 states, including the Alaska Science and Technology Foundation, The Alaska Industrial Development and Export Authority, the Energy \& Environmental Research Center of the University of North Dakota, Usibelli Coal Mines, Placer Dome, Cook Inlet Regional Association and Power Engineers. This commercial demonstration project would produce a liquid coal fuel that would compete with heavy oil in the industrial boiler and utility markets in the Pacific Rim. The process takes advantage of the strengths of Alaska's low. sulfur subbituminous coal while overcoming its main weakness: the high inherent moisture content and low Btu values per pound.

The development of a regional market for coal fuels by installing advanced power systems in Alaska will only help improve the mining and transportation economics of coal in Alaska.

\subsection{Natural Gas Resources}

Alaska has a large natural gas reserve. More than 34 trillion standard cubic feet (Tcf) have been reported to date $(11,12)$. Most of this resource was located in the North Slope region in association with crude oil production at the Prudhoe Bay Field (13). Substantial natural gas reserves also underlie the Upper Cook Inlet area and are used principally in Anchorage. End-use markets for Upper Cook Inlet natural gas include power generation, space heating, feedstock for a chemical plant, and the production of liquid natural gas (LNG) (14).

While 34 Tef is a sizable quantity of gas, a significant write-down of reserves occurred in 1988, when nearly $25 \mathrm{Tcf}$ were removed from the "proved" class. The absence of a market for the gas was the reason for the reclassification. Only gas marketable for North Slope operations and miscellaneous local sales is considered "proved." Proved reserves now total 9.7 Tef. Although lacking a market, the natural gas has an intrinsic value because it is used to increase crude oil recovery through pressure maintenance and other enhanced recovery operations.

Natural gas is also thought to exist as a dispersed resource throughout the interior of Alaska. The location and quantity of this gas is not known; hence it must be characterized with considerable uncertainty. The geology of potential natural gas basins in Alaska and in its state waters is varied and complex. A few basins have exploration wells drilled in them, which can provide comparison data for the many basins that have not been explored. Unfortunately, this means that there is no confirmation of the thickness, geology, or natural gas reserves. This dispersed resource, however, is the target for local production and use in Alaska. Figure 4 shows the location and approximate sites of the natural gas resources in Alaska.

Estimates of undiscovered recoverable conventional natural gas in the Alaskan interior and coastal areas (15). include the following:

- There is a $95 \%$ chance of at least $0.45 \mathrm{Tcf}(0.45$ quadrillion British thermal units [Btus]) being found in Alaskan reserves. 


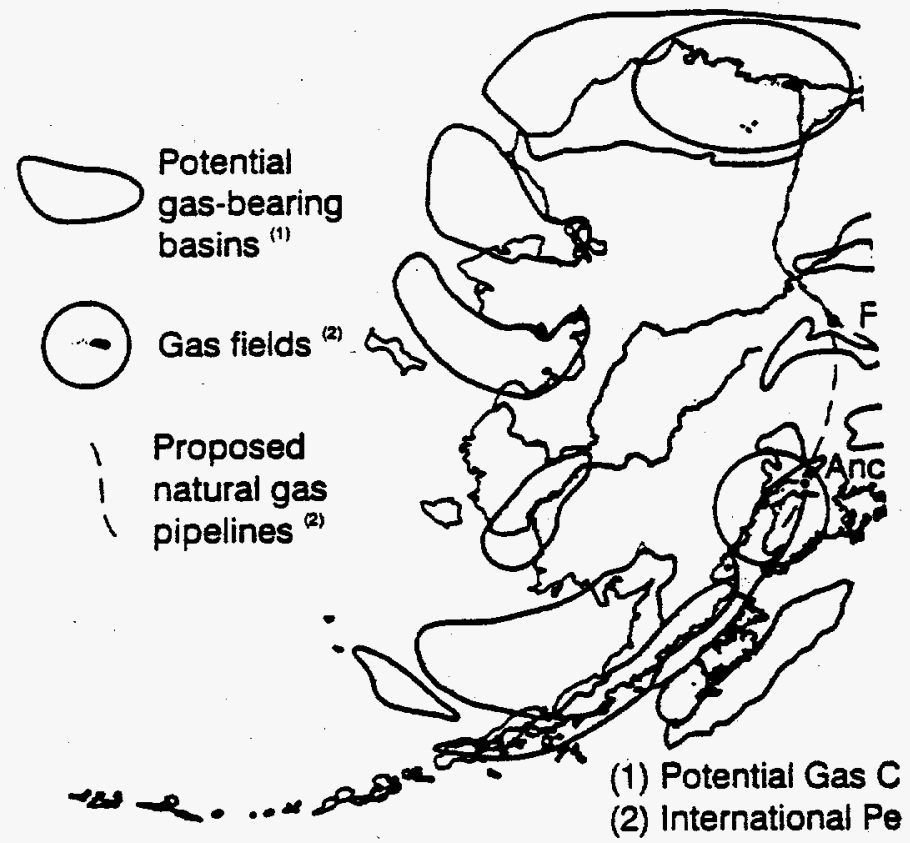

Figure 4. Natural gas resources in Alaska.

- There is a $5 \%$ chance of discovering at least 2.85 Tef (2.85 quadrillion Btu).

- The mean estimate is 1.33 Tef (1.33 quadrillion Btu).

The U.S. Geological Survey is in the process of conducting additional assessments of the natural gas and oil potential in Alaska. Some have characterized the "interior basins" of Alaska as "still active exploration basins" and indicate that the basins are gas. prone (16). It is believed that a large potential exists for producing natural gas for local use (16). These assessments are based on gravity and magnetic mapping surveys. Positive indications of natural gas will still require exploratory drilling. 
However, because of the extremely high cost of operations in Alaska and the cost of a natural gas pipeline to the lower 48 states, in general, it can be concluded that the large oil and gas companies would probably be interested only in world class discoveries in Alaska. The concept of natural gas for local consumption is not strongly pursued by the large integrated oil and gas companies. It logically follows that the development of small natural gas fields, which might serve one of the local villages, would probably be undertaken either by the local village government, a native corporation, or a highly entrepreneurial gas exploration and production company.

An example of how this might come about is exemplified by the North Slope Borough's use of natural gas. The North Slope Borough has a well-organized operation that has drilled for, produces, and transports natural gas for local use in Barrow (population of about 3400). They are producing natural gas from Walakpa Sands, at depths ranging from about 2000 to 2550 feet below sea level. The Walakpa gas field, which has nine producing wells, is located about 18 miles southwest of Barrow. Ice pads were constructed to drill the wells, and a piered pipeline system was built to transport the gas to the community. The project was totally financed by the borough at an estimated project cost of $\$ 20-30$ million. Although the wells are relatively shallow, the drilling cost was several million dollars per well.

There is also the potential for large beds of coal bed methane from the huge coal deposits and associated sands. This year, the state Department of Natural Resources drilled a well near Houston, Alaska. Core samples indicate that 250 to 450 cubic feet of natural gas or methane can be obtained per ton of coal. This 2000-feet-deep test drill passed through five seams of coal, all showing gas potential. The Colorado School of Mines has published an assessment showing that Alaska's minimum coal bed methane resource is over 15,000 trillion $\mathrm{ft}^{3}$.

\subsection{Renewable Energy Resources}

Renewable energy resources are an important option for Alaska. Figure 5 shows that the best wind resources are located along the coast. Although wind resources might prove to be a valuable and clean energy source, wind by its very nature is inconsistent. For a local community that has no other power supply, relying on wind power or solar photovoltaics would be risky. As a consequence, both wind and solar photovoltaic energy resources make the most sense when used in a hybrid power system with the renewable energy system tied directly to a fossil system (i.e., a diesel generator). This combination allows the fossil energy system to ensure the community has heat and electricity when the wind is not blowing and the sun is not shining and to accommodate peak loads. Locations considered for installations include the Pribilof Island in the Bering Sea (17). Wind-diesel hybrid systems are being looked at in Europe. Other hybrid systems using photovoltaics instead of wind turbines are being considered. A $100-\mathrm{kW}$ hybrid system utilizing a wind turbine with an invertor and battery storage, photovoltaics, and a diesel generator is scheduled for installation in Wales, Alaska, in 1995 (18).

Recent advances in the wind power generation and wind-diesel hybrid power systems make this technology a potentially cost-effective option for the coastal communities. The U.S. DOE has an ongoing program to advance wind turbines and to stimulate small wind turbine companies. The goal of this program is to develop, by 1995, turbines that are capable of producing $\$ 0.05 / \mathrm{kWh}$ electricity. The synergism between 
existing U.S. DOE programs to combine development programs for small, fossil fuel-fired power generation systems and wind turbine power generation systems should be actively pursued to ensure that the state's goals of providing safe, reliable, and efficient electricity and heat are met.

\subsection{Regional Power Profiles}

The village populations are small communities which range from 86 to 4200 . The current generation sources are diesel, ranging in size from 50 to $12,600 \mathrm{~kW}$, with peak demands ranging from 100 to $7200 \mathrm{~kW}$. The average cost of electricity for the remote areas of Alaska is about $\$ 0.44 / \mathrm{kWh}$. The residential energy consumption patterns in rural Alaska are significantly different from those in the lower 48 states, as indicated in Figure 6. Detailed statistics on the number of communities, number of customers, power consumption, diesel consumption, and prices are given in Appendix H, Statistical Report of the Power Cost Equalization Program. Regional profiles for the four major regions of Alaska are provided below. The map in Figure 7 defines the four regions and shows the location of the villages in Alaska (see Figure 8 for legend).

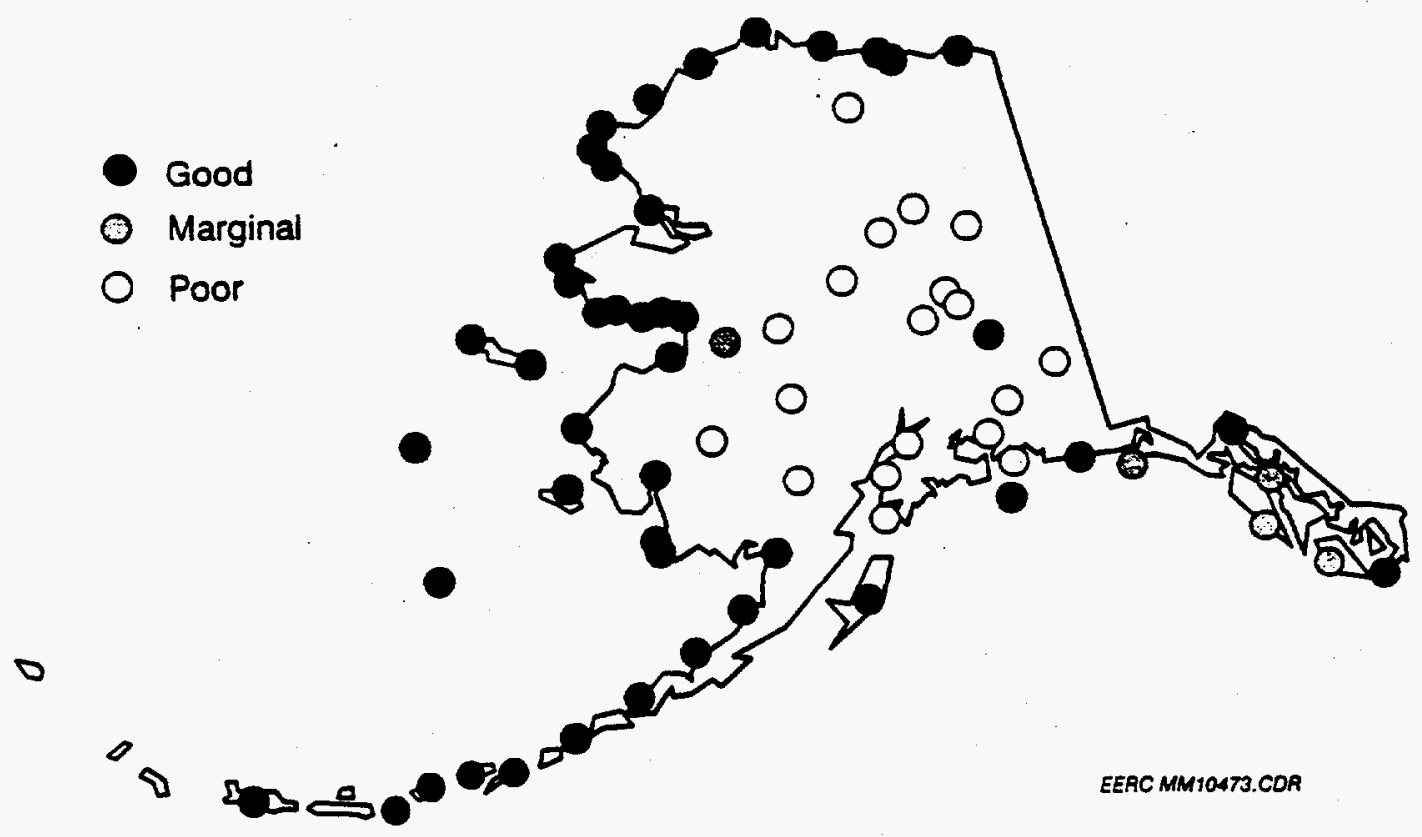

Figure 5. Alaskan locations rated for annual wind power at $30 \mathrm{~m}$ above ground. ("Good" is an average wind speed of $12 \mathrm{mph}$ or greater.) 


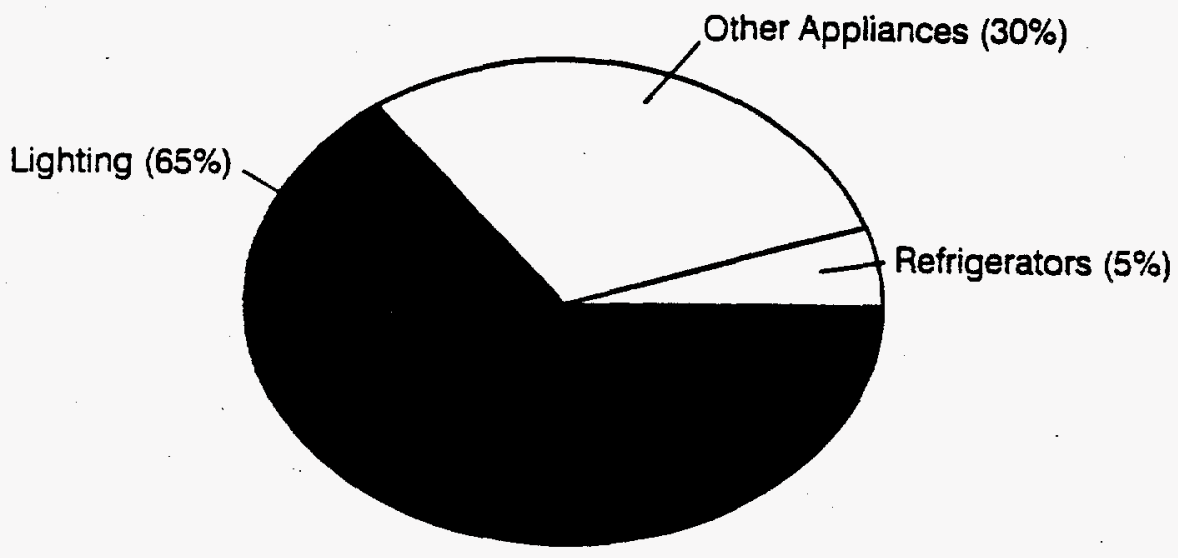

Rural Alaska

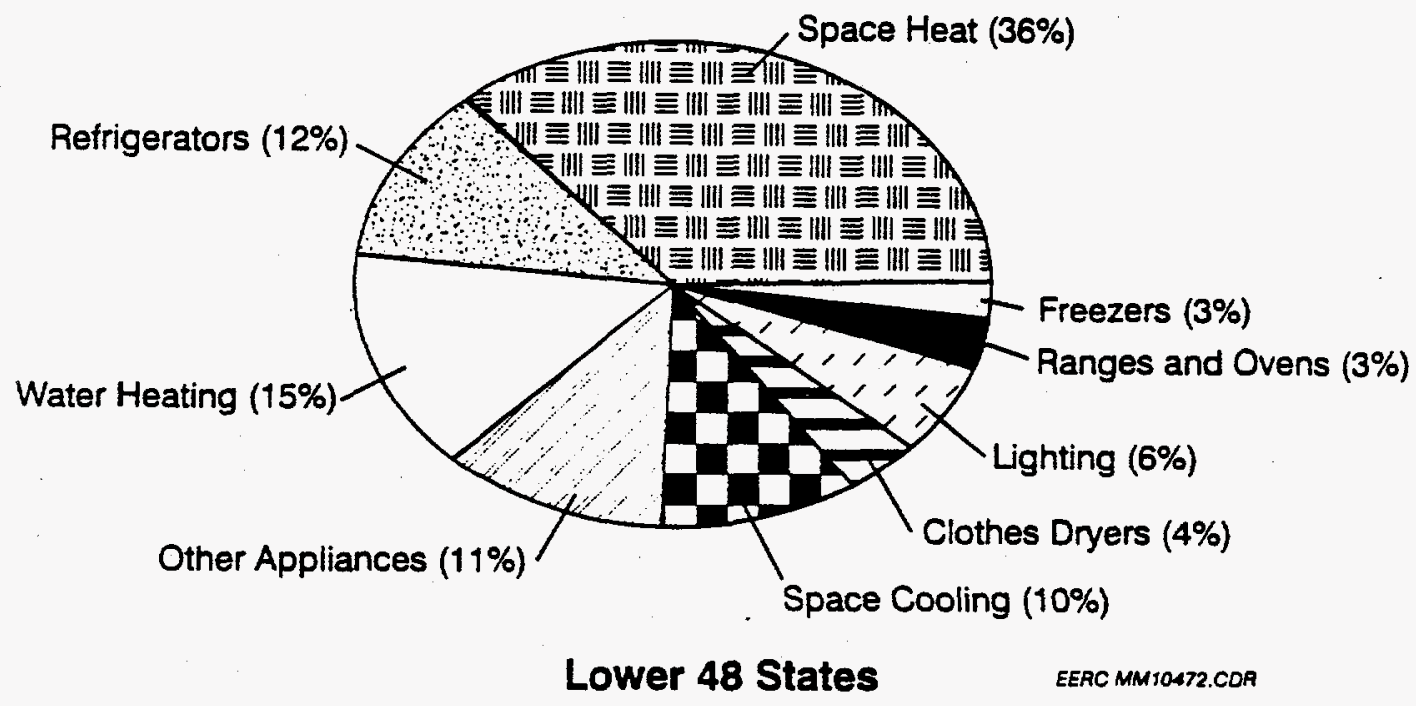

Figure 6. Comparison of residential energy consumption between Alaska and the lower 48 states.

\subsubsection{Southeast Alaska Regional Profile}

Population Size:

Current Generation Sources:

Fuel Use:
Average Individual Customer Demand:

Craig 1455 max., Coffman Cove 175 min. Hydroelectric $6 \mathrm{MW}$, diesel $46 \mathrm{MW}$ Liquid $(4,216,000 \mathrm{gal} / \mathrm{yr})$

Typical community (Tlingit Haida Rural Electric Association) residential load 460 $\mathrm{kWh} /$ month, cost $\$ 155 /$ month, $\$ 0.337 / \mathrm{kWh}$

Maximum and Minimum Loads in Community: Peak demand max. $2200 \mathrm{~kW}$, min.

Average Income:

Expected Power Demand Growth:
$100 \mathrm{~kW}$

$\$ 19,000 /$ capita

$1 \%$ to $3 \%$ 
Other Community Needs:

Available Fuels:

Costs:

Storage Issues:

Average PCE Subsidy per Community:
Waste disposal, especially wood wastes

Woodwastes $\$ 30-\$ 100 /$ bone dry ton Diesel \$0.89/gal avg., \$1.21/gal max., $\$ 0.64 / \mathrm{gal} \mathrm{min}$.

Containment dikes and piping $\$ 0.118 / \mathrm{kWh}$

\subsubsection{Southwest Alaska Regional Profile}

Population Size:

Current Generation Sources:

Fuel Use:

Average Individual Customer Demand:
Bethel 4868 max., Ekwok 110 min. Diesel $12,600 \mathrm{~kW}$, max. and $50 \mathrm{~kW}$ min. Liquid $(9,938,000 \mathrm{gal} / \mathrm{yr})$

Typical community (Kwethluk) residential load $286 \mathrm{kWh} /$ month, cost $\$ 126 /$ month, $\$ 0.44 / \mathrm{kWh}$

Maximum and Minimum Loads in Community: Peak demand max. 5,400 kW, min. $100 \mathrm{~kW}$

Average Income:

Expected Power Demand Growth:

Other Community Needs:

Available Fuels:

Costs:

Storage Issues:

Average PCE Subsidy per Community:

\subsubsection{Yukon Regional Profile}

Population Size:

Current Generation Sources:

Fuel Use:

Average Individual Customer Demand:

$\$ 11,000 /$ capita

$1 \%$

Sewage and waste disposal

Diesel

$\$ 1.27 /$ gal avg., $\$ 2.03 /$ gal max., $\$ 0.74 /$ gal $\min$.

Oil spill containment dikes and piping $\$ 0.205 / \mathrm{kWh}$

Hopper Bay 904 max., Anvik $88 \mathrm{~min}$. Diesel $5730 \mathrm{~kW}$, max., $250 \mathrm{~kW}$ min. Liquid $(3,700,000 \mathrm{gal} / \mathrm{yr})$

Typical community (Nulato) residential load $300 \mathrm{kWh} /$ month, cost $\$ 125 /$ month, $\$ 0.417 / \mathrm{kWh}$

Maximum and Minimum Loads in Community: Peak demand max. $1900 \mathrm{~kW}$, min. 100 $\mathrm{kW}$

Average Income:

Expected Power Demand Growth:

Other Community Needs:

Available Fuels:

Costs:

Storage Issues:

Average PCE Subsidy per Community:
$\$ 11,000 /$ capita

$1 \%$

Sewage and waste disposal

Diesel

$\$ 1.10 /$ gal avg., $\$ 1.81 /$ gal max., $\$ 0.71 /$ gal $\min$.

Oil spill containment dikes and piping $\$ 0.209 / \mathrm{kWh}$

\subsubsection{Arctic/Northwest Regional Profile}

Population Size:

Current Generation Sources:

Fuel Use:
Nome 4184 max., Kobuk $86 \mathrm{~min}$.

Diesel $11,500 \mathrm{~kW}$, max., $50 \mathrm{~kW}$ min.

Liquid $(8,182,000 \mathrm{gal} / \mathrm{yr})$ Average 


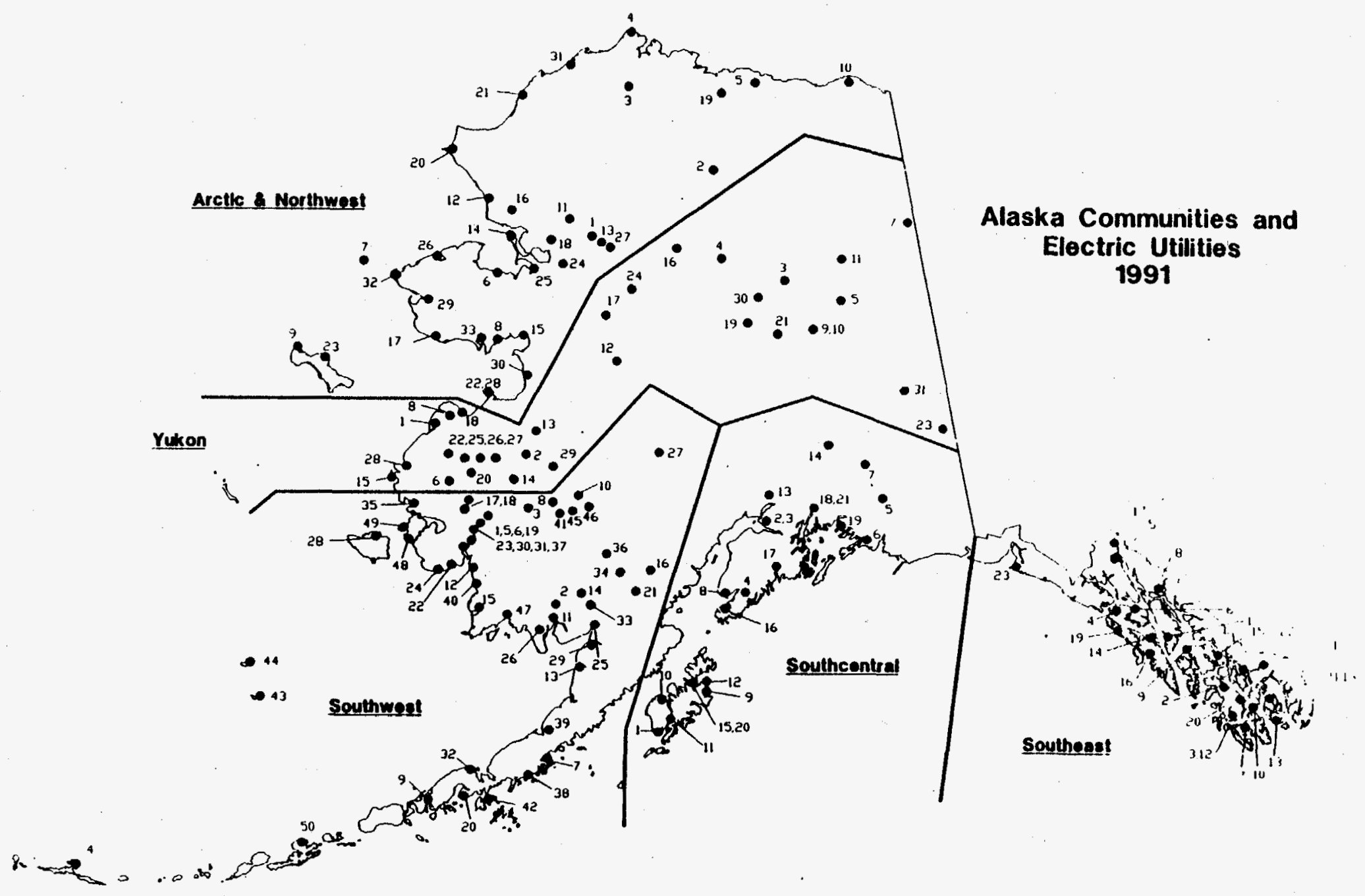

Figure 7. Regional breakout of Alaskan villages used for the workshop. 
LEGEND

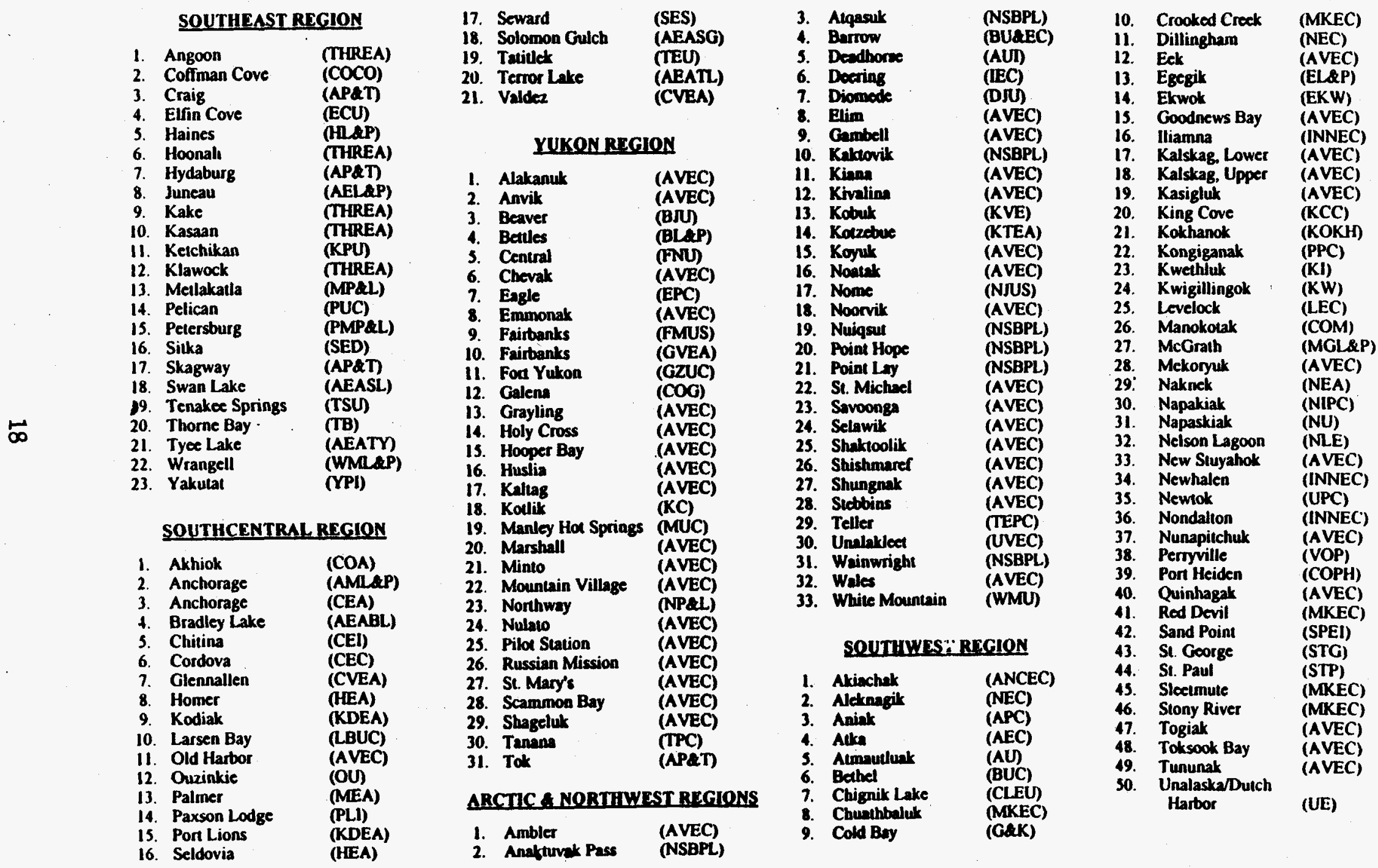

Figure 8. Legend to Figure 7. 
Typical community (Deering) residential load $378 \mathrm{kwh} /$ month, cost $\$ 145 /$ month, $\$ 0.385 / \mathrm{kWh}$

Maximum and Minimum Loads in Community: Peak demand max. 7,200 kW, min. $100 \mathrm{~kW}$

Average Income:

Expected Power Demand Growth: $\$ 10,000 /$ capita

$1 \%$

Other Community Needs:

Available Fuels:

Costs:

Storage Issues:

Average PCE Subsidy per Community:

Sewage and waste disposal

Diesel

$\$ 1.28 / \mathrm{gal}$ avg., $\$ 2.12 / \mathrm{gal}$ max., $\$ 0.76 / \mathrm{gal}$ $\min$.

Oil spill containment dikes and piping $\$ 0.20 / \mathrm{kWh}$

\subsection{TECHNOLOGY OPTIONS}

To introduce Alaskans to potential power systems for remote applications, nine vendor presentations were given. Donald Bonk of METC presented a review of new. technologies applicable to remote power generation. These included diesels, coal-fired diesels, gasification-fired diesels, stokers, coal- and waste-fired fluid-bed combustors, fuel cells and hybrid fuel cells. Vendors representing most of these technologies were present. The highlights of their presentations are given here, with a copy of their papers and/or slides given in Appendix D.

Mr. Michael DeLallo of Gilbert/Commonwealth discussed the option of cofiring municipal solid wastes (MSW) with coal. Some of the advantages cofiring coal with MSW include stabilizing the heat content and moisture of fuel feed and diluting the troublesome constituents of the MSW, such as chlorine. The stable combustion provided by the coal helps keep emission levels in control and results in efficient burnout of the fuel. Some issues that need to be addressed when this option is considered include the fate of residual metals and $\mathrm{HCl}$, storage of infectious and hazardous wastes, feeding, and air emissions. The degree to which these issues are problems is directly related to the type of waste material and the percentage cofired. A conceptual study is currently being considered for cofiring MSW and coal from the Beluga mine.

The attributes of solar, diesel, and battery hybrids were presented by Steve Drouilhet of the U.S. DOE National Renewable Energy Lab. A hybrid system may consist of a wind turbine, photovoltaic cell, battery for storage, and a backup diesel generator. The wind and solar systems complement each other, since the wind blows less in the summer than the winter. The coastal region of Alaska is an ideal place for wind generation. While a Class 3 wind regime is the minimum speed required for economical wind generation, it is not uncommon for wind regimes of Class 7 and 8 to occur in coastal Alaska. The optimal load for this type of system is $80 \%$ renewable and $20 \%$ diesel. Loads of 50 to $100 \mathrm{~kW}$ are easily handled, and units can be packaged in small modular systems. Capacity factors are only $20 \%-40 \%$ though, meaning that the power is not always available.

Upgrading the low-rank coal resources of Alaska was the topic presented by $\mathrm{Mr}$. Michael Mann of the University of North Dakota Energy \& Environmental Research 
Center. Three processes were discussed. The Rosebud process uses thermal drying to produce a low-moisture, high-Btu product with some reduction in sulfur. Problems associated with dried low-rank coals are addressed by treating the dried coal with an additive. The Encoal process pyrolyses the coal to produce a dry char product and a liquid product similar to No. 6 oil. These two processes are currently being demonstrated under the U.S. DOE Clean Coal Program. A third upgrading process was the EERC hot-waterdrying process. This process essentially produces a slurry using the moisture present in the raw coal through treatment at elevated pressures and temperatures. The resultant pumpable slurry has a heating value similar to that of the raw coal and can serve as a replacement for dry coal or oil in many applications. Negotiations are currently underway for a demonstration of this process in Alaska. The importance of any of these three processes is that they can produce a viable product for export, in addition to a quality fuel for power generation use in Alaska.

Mr. John White of Cooper Energy Services (Cooper Bessemer) presented the option of coal-fired diesel engines. The coal-fired diesel has the advantage of being somewhat similar to the diesel engines currently in use in Alaska and, therefore, may not be as intimidating to users as are totally new technologies. The coal-fired diesels are currently on the verge of being commercially offered. Cooper Bessemer currently has 1000 hours of operation firing coal in a diesel engine and has demonstrated low emissions on $\mathrm{NO}_{\mathrm{z}}$, good particulate control, and no derating. A 4000-hr field demonstration at Easton Utilities Maryland is planned as a part of Clean Coal V. Cooper Bessemer is currently doing a feasibility study for the state of Alaska and has identified Beluga (mining power), Valdez (refinery power), Red Dog (mining power), Kodiak or St. George (fish plant), and Bethel (intermediate size village for power) as good potential sites for a demonstration.

Fuel cells, driven by either hydrogen or natural gas, were presented as potential options by Mr. Scott Hynek of Arthur D. Little and Mr. William Lueckel of International Fuel Cells. A hydrogen fuel cell would generate hydrogen through the electrolysis of water. This hydrogen would then be used as fuel to the fuel cell. One potential way to tie into Alaska's natural resources is to couple the fuel cell with a wind turbine. When the wind is blowing, the wind turbine could provide enough power to meet the demands of the village and enough extra power to generate and store hydrogen. During periods of no wind activity, the stored hydrogen could be used to generate power in the fuel cell. The electrolysis unit, wind turbine, and hydrogen storage system are off-the-shelf items. An alternative method of operating the fuel cell is with gas. Coal bed methane associated with the coal seams is one source of gas, while compressed or liquified natural gas from the natural gas wells on the North Slope or Cook Inlet are a second. The number of fuel cells in commercial operation is increasing in the lower 48 states of the United States.

There are a number of externally fired turbine/combined cycle processes being developed by U.S. DOE. These processes heat pressurized air to temperatures as high as $2300^{\circ} \mathrm{F}$ to drive a gas turbine and use a conventional heat recovery steam generator to drive a steam turbine. Mr. William Smith from U.S. DOE/METC presented an overview of the Hauge process, the PENELEC Clean Coal $V$ process, and high-performance power systems (HIPPS). Although these processes are currently not commercial, they may be viable by 2000 . They offer the advantage of high efficiencies with low operating costs.

The main product of the Will-Burt Company is stokers. They offer some as small as space heaters for single rooms, while their current line of products ranges from 70,000 to 
7,000,000 Btu/hr. Mr. Rod Webner presented a new product line, a fluid.bed combustion (FBC) system developed in conjunction with Ohio Agriculture Research and Development and Energy and Environmental Research Corporation (EER). The output of this FBC is $1000^{\circ}$ to $1500^{\circ} \mathrm{F}$ clean air that can be used for heat or to produce electricity. This simple system uses one fan to provide fluidizing air and coal and ash transport and injection air. A demonstration of the technology is in progress in Ohio. Application of the Will-Burt system in an Alaskan village has been reviewed. This study proposed an atmospheric fluidized-bed combustion (AFBC) hot-air gas turbine (HAGT) using the Brayton cycle. The project would cost $\$ 4$ million capital with a projected $\$ 0.18 / \mathrm{kWh}$ cost of electricity. This system will break even with diesel at that location even with coal at $\$ 80 /$ ton.

Mr. Chuck McMenamy of DONLEE Technologies also presented their commercial system based on FBC technology. Of particular interest was its $6-M W_{\text {th }}$ FBC to cofire hospital wastes with coal. This unit, currently under construction in Lebanon, Pennsylvania, will fire $2400 \mathrm{lb} / \mathrm{hr}$ anthracite coal, $300 \mathrm{lb} / \mathrm{hr}$ infectious wastes, and 120 $\mathrm{lb} / \mathrm{hr}$ limestone. One of the more difficult tasks associated with this project was the shredding and feeding of the waste materials. This technology presents the opportunity to deal with the MSW and sewage waste problems currently encountered by many Alaskan villages. DONLEE currently offers products in the range of 3 to $18 \mathrm{MW}$ th. A system similar to the co-fired hospital waste system is being considered for McGrath Alaska under a separate U.S. DOE/METC CRADA.

Firing of wood waste was the topic of Mr. Peter Bloomfield of Bloomfield and Associates. They have gained experience in wood firing from the New England states, where they have a number of plants in the 9- to 22-MW range, some up to $50 \mathrm{MW}$ firing wood. The extensive forest product industry makes firing wood viable, as it would not be viable in the New England area if the wood was harvested only for power. One ton of green wood is equivalent to 47 gallons of No. 6 oil, 49 gallons of No. 2 oil, $500 \mathrm{lb}$ of 13,000 $\mathrm{Btu} / \mathrm{lb}$ coal, or $6400 \mathrm{ft}^{3}$ gas. Characteristically, wood is $4250 \mathrm{Btu} / \mathrm{lb}, 50 \%$ water, $0.2 \%$ to $2 \%$ ash, no sulfur, and produces a fine-grained ash that is used as fertilizer in New England. Ninety percent of the problems associated with wood firing are related to handling and feeding. With proper fuel handling and preparation, these problems can be minimized, and wood wastes can be turned into a valuable energy resource.

Posters were also presented at the workshop by several vendors who spoke at the workshop and by other vendors including Foster Wheeler Energy Corporation, Sunpower, Inc., and MTCI/Thermo-Chem Inc.

Mr. Peter Bloomfield provided a good summary of the technology options and their interface with Alaska. He emphasized that any solution will be site-specific. The people on-site must be willing and committed to making the technology work. Any of the proposed systems are more complicated than the diesels currently providing power at the remote villages.

\subsection{REGIONAL INPUT}

The highlight of the workshop was the breakout session that followed the technical presentations. The purpose of the breakout session was to provide a forum for local users and providers of services to share experience, concerns, and solutions. The original intent 
of the CRADA was reemphasized by Commissioner Blatchford: to make sure that the principal stakeholders have an opportunity to speak, share their thoughts, and provide the critical local input that is needed to make the introduction of alternative technologies into Alaskan communities successful. To facilitate this, four breakout groups were formed according to the regions identified in Section 6.4. Two facilitators were assigned to each group: one from DCRA and one from METC, with recorder support from EERC. Detailed notes from the breakout sessions are presented in Appendix E. Summarized conclusions by each region of the state are provided below.

\subsection{South East/South Central Region}

- Wood waste is a major environmental issue. Might be used as a major fuel source. There is an opportunity for synergism between heating and electric power.

- Decreasing the amount of oil used by the community while reducing piles of wood waste is a plus.

- Even though transportation of diesel is not as much a problem in this region, the use of local resources is very important socially.

- Understanding the growth of the electric grid is a factor in determining sites and the viability of any solution.

- The logistics and cost of providing the wood fuel are the principal issues related to burning the wood.

- The state needs to clearly communicate policy and objectives.

\subsection{Arctic and Northwest}

- Integrated solutions are needed that address multiple issues; a principal emphasis was put on improving health through proper disposal or use of wastes.

- Private financing options are acceptable as long as the community issues are also considered-like jobs for the community. The Red Dog mine was mentioned as a good example of how this has worked in the past.

- The needs of the village should be the focus, not the desire to create a whole new technology. Don't force technologies down community throats.

- Don't study things to death, as has been done in the past; build demonstration projects.

- Demonstrations are important before anyone buys into the technology: "need to kick the tires." 


\subsection{Southwest}

- U.S. DOE and/or the state needs to develop life cycle cost models for the technology options presented so they can be reviewed by local utilities.

- Resource definitions of coal, coal bed methane, and natural gas for this region are not adequate. A better mapping of resources needs to be done.

- Southwestern Alaskans would like to use local resources and have costs associated with current technologies and alternatives defined.

- A systems approach is needed, integrating energy, heating, transportation, and waste disposal.

- The state should get involved in coordinating and leveraging fuel purchasing and distribution.

- Training is important for existing technologies and critical for new technologies. Cultural considerations have to be taken into account for small rural villages.

- Environmental regulations are not workable and are not really applicable to these areas.

\subsection{Yukon}

- Site identification should be user-driven and based on existing information. The state has a lot of information it can apply, but should not dictate.

- A suite of technologies must be identified.

- Education about energy use should be stressed with the goal of changing energyconsuming habits, and improving energy efficiency should be promoted.

- The state's energy and environmental policy needs to be better communicated.

- The activity needs to focus on using indigenous fuels and producing local jobs.

- Any new technology has to be cost-competitive when and if the state's Power Cost Equalization Program is discontinued.

- Coal companies need to be willing to work with alternative energy production.

- The development of an algorithm for technology selection would be useful. This algorithm should try to use technical, environmental, economical, and social considerations to choose the technology.

- Communication between users and state and federal government needs improvement. This needs to include information on policy and programs. There needs to be true interaction instead of demanding the end user fill out forms and questionnaires. 
- Vendors want more information developed regarding specific Alaska site situations.

\subsection{CONCLUSIONS AND RECOMMENDATIONS}

The Small Alternative Power Generation Workshop held in Anchorage was a first step in meeting the statutory mission of the Alaskan Division of Energy: to assist in the development of safe, reliable, and efficient energy systems throughout Alaska that are financially viable and environmentally sound. The workshop was a success in that it established good three-way communication among government policymakers, suppliers of technology, and the end user, Alaskans. As a result of interactive presentations and breakout discussion groups, the needs of the Alaskans were heard, and a number of technology options were offered that could meet these needs. The U.S. DOE is meeting the intent of the President's April 29, 1994, Executive Order through this workshop and other communication processes to make sure that native tribes are fully aware and participating in the investigation of small power systems.

A number of problems were identified by Alaskans as needing consideration with respect to identifying alternative power systems. The current use of diesel fuel presents environmental problems related to its transport and storage. Diesel fuel is also expensive and results in a large share of the local dollars flowing out of the community. Another major issue facing many Alaskan villages is waste disposal, including sewage sludge, MSW, and wood waste.

The Alaskans identified a number of needs during the breakout sessions. They are interested in an integrated solution, one that addresses energy, heating, transportation, and waste disposal needs. A principal emphasis should be on improving health, in addition to being more friendly to the environment and more cost-effective than the current diesel generators.

The use of local resources is important. The villages would like to create more jobs and keep more dollars in the local economy. There was a consensus that a better resource evaluation was needed to make the appropriate decisions on which local resources would present the best investment opportunity. Better communication of the state's energy and environmental policy also will play an important role in these decisions.

It was strongly suggested that there is a need for technology demonstrations. The Alaskans are tired of paper studies that do nothing to correct the current situation. These demonstrations would serve two purposes: to begin the process of replacing diesel engines and, more importantly, to provide sites where potential users of the new technologies could come for a firsthand look at the technology meeting the needs of rural Alaska and its unique conditions. It was stressed that site identification should be user-driven and based on existing information. It was anticipated that a number of technologies would be chosen for demonstration, since the needs and resources differ between communities.

A number of technologies were presented at the workshop that appear to meet the demands of Alaskan utilities. Several systems were suggested that can use coal, biomass, and other refuse as fuel sources. These include fluid-bed combustors and multifuel stokers. Coal-fired diesels could capitalize on a coal-water fuel (CWF) demonstration 
plant planned in Alaska. The environmentally benign CWF will create an export market while providing a viable fuel for local villages. Other systems, such as fuel cells, take advantage of natural gas or coal bed methane that is abundant in many regions of Alaska. These systems provide cleaner, more user-friendly, and perhaps lower-cost energy options for the production of heat and electricity in Alaska. Hybrid systems of wind, photovoltaics, battery storage, and diesel generators also provide a technically feasible option, but are considerably more expensive than the others.

Based upon the input provided at this workshop, DCRA and U.S. DOE/METC will conduct four feasibility studies as the second phase of their CRADA. Fluidized-bed combustion, coal-fired diesel, and fuel cell applications for power generation in remote sites in Alaska are currently the technologies that will be studied. Preliminary sites selected were Bethel on the lower Kuskokwim River, Tok on the highway system in interior Alaska, Tanana on the upper Yukon River, and one of several remote North Slope villages yet to be determined. These sites were selected because they represented communities with a good chance of hosting successful demonstration projects. Bethel is an attractive site for coal technology because it has good barge transportation access and an experienced utility. With a population of 4,600 , Bethel is representative of the larger villages. At a population of 400 , Tok is representative of the smaller interior Alaskan villages. Tok is a major transportation center in close proximity to coal and biomass resources. AFBC technology capable of firing multiple fuels was chosen for Tok. Tanana is located on the upper Yukon River where coal natural gas could potentially be economically transported for use in a fluidized bed system or fuel cell which is used principally to meet the heating needs of the community. The North Slope village will be a candidate for a fuel cell because of the natural gas in the area and will be selected based upon an electrical demand of slightly less than $200 \mathrm{~kW}$. Other possible fuel cell sites will be given some preliminary study to see if a rapid development and demonstration could be possible in the 1995-1996 period.

Rapid development of these technologies should be a priority in direct response to Alaskan's strong requests for demonstrations rather than more studies.

\subsection{REFERENCES}

1. Alaskan Energy Authority. Annual Report, 1992.

2. Energy Information Administration. Annual Energy Outlook 1993; January 1993 U.S. DOE/EIA-0383 (93).

3. "Rural Alaska Bulk Fuel Assessment Program, Summary Report and Recommendations," Alaska Energy Authority, March 1992.

4. The Calista Region, A Gentle People - A Harsh Life; 2nd ed., Calista Corporation, Land and Natural Resource Department and Village Management Services: Anchorage, AK, Oct. 1991.

5. Eschenbach, T.G.; Geistauts, G.A.; Jones, G.N. "Technology Transfer in Alaska: A Developing Region of a Developed Nation," In Proceedings of the 1st International Conference on Technology Management; Feb. 1988. 
6. Knapp, G. "Economic Development in Alaska and the Third World, Similarities and Contrasts," In Proceedings of the Arctic Science Conference; American Association for the Advancement of Science, Anchorage, AK.

7. Willson, W.; Yufu, L. "Power Generation from an Alaskan Low-Rank Coal-Water Fuel: Preliminary Phase 1 Report," Oct. 1990.

8. Stiles, R.B. (President - Alaska Coal Association). "Export Potential of Alaska Coals," Presented at the 17th Biennial Low-Rank Fuels Symposium, May 1993.

9. Strickler, G.D. (U.S. Geological Survey, Denver, CO); "Alaska Has 4.0 Trillion Tons of Low-Sulfur Coal; Is There a Future for this Resource?"; Presented at the Annual Convention and Exposition of the American Association of Petroleum Geologists, May 1990.

10. Bradner, T. "Coal Opportunity Like Chicken vs Egg," Anchorage Daily News; Sunday, April 5, 1992.

11. Energy Information Agency. "U.S. Crude Oil, Natural Gas, and Natural Gas Liquids Reserves 1988 Annual Report," U.S. DOE/EIA-0216 (88).

12. Energy Information Agency. "U.S. Crude Oil, Natural Gas, and Natural Gas Liquids Reserves 1991 Annual Report," U.S. DOE/EIA-0216 (91).

13. Thomas, C.P., et al; "Alaska Oil and Gas: Energy Wealth of Vanishing Opportunity?" final report U.S. DOE/DD/01570-H1; Jan. 1991.

14. "Estimates of Undiscovered Conventional Oil and Gas Resources in the United States - A Part of the Nation's Energy Endowment," U.S. Geological Survey/MMS, 1989.

15. Telephone Conversation with Tim Collet, U.S. Geological Survey, Denver CO, May 24, 1993.

16. Clevenger, M. "Rural Electrification In Alaska," Diesel Progress North American, Nov. 1985.

17. Durand, S.J.; Bower, W.; Chapman, R.; Smith, G. "The Alaska Energy Authority PV-Diesel Hybrid Assessment and Design Program," In Proceedings of the 21st IEEE Photovoltaic Specialists' Conference; 1991. 
APPENDIX B

GLOBAL MARKET ASSESSMENT OF COALBED METHANE, FLUIDIZED-BED COMBUSTION, AND COAL-FIRED DIESEL TECHNOLOGIES IN REMOTE APPLICATIONS 


\section{ENERGY}

RESOURCES

INTERNATIONAL, INC.

\section{GLOBAL MARKET ASSESSMENT \\ OF COALBED METHANE, FLUIDIZED BED COMBUSTION, AND COAL-FIRED DIESEL TECHNOLOGIES IN REMOTE APPLICATIONS}

Prepared for:

Energy \& Environmental Research Center

Prepared by:

Jack S. Siege!

David W. South

March 15, 1996

1015 18th Street, N.W., Suite 650

Washington, DC 20036 U.S.A.

Telephone: (202) 785-8833

Facsimile: (202) 785-8834 


\section{TABLE OF CONTENTS}

Executive Summary

1.0 Technology Characterization

1.1 Coalbed Methane

1.2 Small-Scale Fluidized-Bed Combustion

1.3 Coal-fired Diesels

2.0 Factors Influencing The Market Potential Of Remote Power Technologies

2.1 Coalbed Methane

2.2 Small Scale Fluidized Bed Combustors

2.3 Coal-fired Diesels

3.0 Coalbed Methane Recovery And Use 6

3.1 Global Prospects 6

3.2 Potential in Remote Regions 6

3.3 Country A ssessments 6

3.3.1 Russia 8

3.3.1.1 Population and Land Use $\quad 8$

3.3.1.2 Energy Resources $\quad 12$

3.3.1.3 Coalbed Methane Recovery Potential
3.3.4 Potential Applications for Coalbed Methane In Russia

3.3.2 Ukraine 15

3.3.2.1 Population and Land Use 15

3.3.2.2 Energy Resources 15

3.3.2.3 Coalbed Methane Recovery Potential 15

3.3.2.4 Potential Applications for Coalbed Methane in the Ukraine $\quad 16$

3.3.2.5 Barriers to the Recovery and Use of Coalbed Methane in Russia and Ukraine

3.3.3 South Africa

3.3.3.1 Population and Land Use

3.3.3.2 Energy Resources

3.3.3.3 Coalbed Methane Recovery Opportunities

3.3.3.4 Potential Uses for Coalbed Methane

3.3.3.5 Barriers to the Development of Coalbed Methane 21

3.3.4 China

3.3.4.1 Population and Land Use $\quad 22$

3.3.4.2 Energy Resources 22

3.3.4.3 Coalbed Methane Opportunities 26

3.3.4.4 Potential Uses for Coalbed Methane in China 28

3.3.4.5 Barriers To the Recovery of Coalbed Methane in China 28

3.3.5 Poland 29

3.3.5.1 Population and Land Use 29

3.3.5.2 Energy Resources 29

3.3.5.3 Coalbed Methane Recovery Potential 31

3.3.5.4 Potential Markets for Coalbed Methane in Poland 33

3.3.5.5 Barriers to the Recovery of Coalbed Methane in Poland 33 
3.3.6 India 34

3.3.6.1 Population and Land Use $\quad 34$

3.3.6.2 Energy Resources $\quad 34$

3.3.6.3 Coalbed Methane Recovery Potential 36

3.3.6.4 Potential Markets for Coalbed Methane in India 38

3.3.6.5 Barriers to the Recovery of Coalbed Methane in India $\quad 38$

4.0 Global Prospects For Small-Scale, Fluidized-Bed And Coal-Fired

Diesel Power Systems In Developing Countries 39

4.1 Market Assessment: Africa 39

4.1.1 Mozambique 39

4.1.2 Tanzania 41

4.1.3 Malawi 41

4.1.4 Burundi 41

4.1.5 Zaire $\quad 42$

4.1.6 Madagascar $\quad 42$

4.1 .7 Nigeria 43

4.1 .8 Niger 43

4.1.9 Kenya

4.1.10 Ghana 44

4.1.11 Zambia 45

4.1.12 Mauritania 45

4.1.13 Egypt 46

4.1.14 Zimbabwe 46

4.1.15 Morocco 47

4.1.16 Cameroon $\quad 48$

4.1.17 Tunisia 48

4.1.18 Algeria $\quad 48$

4.1.19 Mauritius 49

4.2 Market Assessment: Asia 49

$\begin{array}{lll}4.2 .1 & \text { Nepal } & 49\end{array}$

4.2.2 Laos 50

4.2.3 Bangladesh $\quad 50$

4.2 .4 India 51

4.2 .5 China 52

4.2.6 Pakistan $\quad 54$

4.2.7 Sri Lanka $\quad 55$

4.2.8 Indonesia $\quad 55$

4.2.9 Myanmar $\quad 57$

4.2.10 Vietnam 57

4.2.11 Philippines 58

4.2.12 Papua New Guinea $\quad 59$

4.2.13 Thailand $\quad 59$

4.2.14 Malaysia 60

4.3 Market Assessment: Centra//Eastern Europe 61

4.3.1 Romania 61

4.3.2 Poland 61

$\begin{array}{lll}\text { 4.3.3 Bulgaria } & 62\end{array}$ 
4.4 Market Assessment: Middle East/Near East 62 4.4.1 Turkey $\quad 62$

4.5 Market Assessment: Central/South America 63

$\begin{array}{lll}4.5 .1 \text { Peru } & 63\end{array}$

4.5.2 Columbia 64

4.5.3 Panama 64

4.5.4 Chile . 65

$\begin{array}{lll}\text { 4.5.5 Argentina } & 66\end{array}$

4.6 Assessment Of Technology Market Potential And Barriers 67

$\begin{array}{ll}4.6 .1 \text { Africa } & 67\end{array}$

$\begin{array}{lll}4.6 .2 \text { Asia } & 70\end{array}$

$\begin{array}{ll}\text { 4.6.3 Central/Eastem Europe } & 74\end{array}$

4.6.4 Middle East/Near East $\quad 74$

$\begin{array}{ll}\text { 4.6.5 Central/South America } & 79\end{array}$

$\begin{array}{ll}\text { References } & 82\end{array}$

Attachment 1: The Alaskan Initiative $\quad$. 84

3-1 Map of Russia $\quad 10$

3-2 Population Density of Russia $\quad 11$

3-3 Major Coal Basins of the Former Soviet Union 13

3-4 Transmission Network and Power Plants in the Ukraine 17

3-5 South Africa: Geographic Regions 19

3-6 South Africa: Principal Coal Fields 20

3-7 China: Population Density by Province (1989) 23

3-8 China: Terrain Map 24

3-9 China: Principal Coal Basins 25

3-10 Location Map of China's Coal Basins and Estimated Methane Resources 27

3-11 Regions of Poland $\quad 30$

3-12 Location of Coal Basins, Oil Fields, and Gas Fields, Poland $\quad 32$

3-13 Topography of India $\quad 35$

3-14 India: Principal Coal Fields 37

3.1 CBM Recovery Potential in Countries with Largest Coalbed Methane Resources $\quad 7$

Population Characteristics in Countries with Largest Coalbed
Methane Resources

4.6.1 Market Indicators Summary: Africa 68

4.6.2 Market Potential Rating: Africa $\quad 69$

4.6.3 Market Indicator Summary: Asia $\quad 71$

4.6.4 Market Potential: Asia $\quad 72$

4.6.5 Market Indicators Summary: Central/Eastern Europe 75

4.6.6 Market Potential Rating: Central/Eastern Europe 76

4.6.7 Market Indicators Summary: Middle East/Near East 77

4.6.8 Market Potential Rating: Middle East/Near East.

4.6.9 Market Indicators Summary: Central/South America 80

4.6.10 Market Potential Rating: Central/South America 81 


\section{EXECUTIVE SUMMARY}

\section{Background}

Over the past five years, the Morgantown Energy Technology Center (METC) of the Department of Energy has been working with U.S. industry, Native Alaskans and Alaska state and local officials to demonstrate the viability of a variety of technologies to meet the energy, economic and environmental needs of the remote villages of Alaska. In 1995, METC contracted with the Energy and Environmental Research Center (EERC) to manage the program. EERC retained Energy Resources International, Inc. (ERT) to support them in developing and implementing a strategy to carry out the program and to conduct a broad, first order assessment of the international market potential of the technologies proposed for demonstration in Alaska. This report presents the results of the global market assessment.

The technologies proposed for demonstration in Alaska and, therefore, the technologies which are the focus of this study include: small scale (less than $10 \mathrm{MW}$ ) coal or mixed fueled fluidized-bed combustors, coalbed methane recovery (from active mining operations) linked to a gas-based generator of electricity (e.g., fuel cells, gas combustor, gas turtine). and coal-fired diesel generators. The Alaskan Initiative, which includes a brief description of the subject technologies, is provided in Attachment 1.

To cany out this assessment, the following steps were undertaken:

- The subject technologies were characterized (Section 1);

- The most important features of each technology, which could influence their market potential, were identified (Section 2);

- An assessment was conducted to determine those countries with the greatest market potential for each technology. The assessment considered factors such as the overall energy market size, private power developments/privatization, rural energy needs and the proximity of fuel (coal or coalbed methane) to the rural communities. This assessment was conducted for coalbed methane recovery from active mines (Section 3), and coal-fired fluidized-bed combustors and coal-fired diesels (Section 4); and

- Estimates of the market potential of each technology (by country) were compiled when sufficient reliable information was available. The technology and market hurdles that will have to be removed before their potential is realized were also summarized. This information is presented in Section 3 for coalbed methane recovery, and Section 4 for fluidized-bed combustors and coal-fired diesels.

This assessment is intended to provide a ballpark estimate of the market potential of the technologies. Site specific, case-by-case analysis of the technologies in individual countries (and communities) is necessary to determine the true market size for the technologies.

Findings

Large market potential was identified for each of the technologies analyzed. Due to differences with in-country market conditions and the availability/quality of power market information, a composite (quantitative) picture of the market for these technologies could not be prepared for inclusion in this 
report. Instead, only a qualitative assessment is possible.

The developing countries with the greatest near-term market potential for coal-bed methane recovery from active mines are: Russia, Ukraine, South Africa, China, Poland, and India. Based on existing mining operations in these countries, and assuming that $25-35 \%$ of the coalbed methane released from these mines is recoverable, then 181 to 459 billion cubic feet (BCF) per year could be available (in the near-term) for consumption in the identified markets. Greater recovery rates at existing mines and the inclusion of recovery at new mines expands the potential market considerably. A more detailed assessment is required, however, to quantify this opportunity. To realize the near-term (and longerterm) market potential of coalbed methane requires the removal of particular market barriers: capital cost of projects; cost of installing coalbed methane systems; lack of clear legal authority (and precedent) regarding ownership of the resource; and lack of understanding of the resource and its value, in-country.

The countries with the greatest market potential for small-scale fluidized bed combustors (FBC) and coal-fired diesels (CFD) are identified below by region:

Africa: Zimbabwe, Morocco

Asia: India, China, Pakistan, Indonesia, Vietnam, Philippines, and Thailand

Central/East Europe: Poland, Bulgaria

Middle East/Near East: Turkey

Central/South America: Peru, Columbia, Chile

Each of these countries were rated with "high" market potential for FBC and CFD technologies. The rationale for this rating includes:

- they are currently using coal for power generation, and thereby have the coal infrastructure inplace;

- they are projected to realize high growth rates in demand (> $6 \%$ per annum) and/or require investment in replacement capacity,

- they have a high percentage of rural population $(>50 \%)$ and/or have isolated load centers due to topographical conditions;

- a small percentage of the rural population has access to the electric grid;

- the countries have policies to increase rural electrification and diversify their fuel sources (including reduced oil consumption by diesel generators); and

- they have private power development incentives and/or privatization programs, either in-place or proposed.

While the amount of new/replacement generating capacity in these countries range from $400 \mathrm{MW}$ (Zimbabwe) to $400 \mathrm{GW}$ (China), there remains a viable market for FBC and CFD technologies in remote applications within each of the identified countries for the aforementioned reasons. A more detailed assessment of the current power system and load demand in these remote areas is required before a quantitative estimate of the market potential for these technologies can be derived.

The major barriers to deployment of these technologies are: 1) competition with hydroelectric and natural gas technologies, which is prevalent in these countries due to resource availability; 2) capital availability, which is limited and generally requires external private power investors; and 3) lack of local information about (and benefits of) these technologies and their use in a micro-grid. 


\section{Recommendations}

Significant market opportunities exist for each of the technologies being considered for demonstration in Alaska. To take advantage of these opportunities, the following are recommended:

(1) Proced with the Alaskan Initiative as quickly as possible. Demonstration of the small scale fluidized-bed combustor and the coal-fired diesel are key to the utilization of these technologies in other parts of the World. This is less true for coalbed methane recovery which is already being carried out in most of the priority markets identified.

(2) Share the results of the Alaskan demonstrations with the appropriate representatives in the high potential market countries. Information on the technologies, their attributes and their costs should be shared to confirm their potential markets and to identify the most effective course of action to take to introduce the technologies into each country. As the demonstrations progress, information updates should be provided. The information dissemination should be undertaken with the involvement of the technology vendors and project developers and can take the form of seminars, workshops or one-on-one meetings with country representatives.

(3) The findings of this study should be shared with the Agency for International Development, the U.S./Asia Environmental Partnership, the Department of Energy, the Small Business Administration, the Trade Development Agency and other U.S. federal agencies that may have an interest and resources to help to introduce the technologies into the foreign markets. These agencies have the mandate to undertake programs and projects to eliminate poverty and pollution in the developing countries and/or to assist U.S. companies in the export of their goods and services. Use of the subject technologies could help to achieve those objectives. As a result, follow-on programs could be developed with them.

(4) The findings should also be shared with the United Nations Development Program, the World Bank and other multilateral organizations charged with economic development in the developing World. The objective of working with them is to identify funding sources for follow-on studies, conferences, workshops and seminars, training and education programs and pilot projects to introduce the technologies to the target countries. 


\subsection{TECHNOLOGY CHARACTERIZATION}

\subsection{Coalbed Methane}

The recovery of methane from operating and undeveloped coal mines has been practiced for many years in many places throughout the World. Coalbed methane recovery is similar in nature to the recovery of natural gas and uses similar exploration, drilling and recovery technologies. However, in most cases, the quantity of coalbed methane resource at a given site is considerably smaller than typically required for an economic natural gas field development.

There are many attributes that coalbed methane recovery offers. These include:

- Similarity to Natural Gas. The methane that is produced is clean (or can be cleaned). Once removed from the ground, it can be handled, transported and used like natural gas (although its transport and use will depend upon its quality).

- Multiple Uses. Methane can be used to produce a wide variety of products including electricity, heat and chemicals.

- Easy to Transport and Use. Methane can be transported by pipeline and used in boilers, furnaces and other end-use devices without the need for highly trained personnel, and with very few operations and maintenance (O\&M) staff.

- Environmental. Methane released to the atmosphere is a highly reactive greenhouse gas. However, if it is captured and utilized, its environmental effects are similar to those of natural gas no sulfur dioxide, very low nitrogen oxides, non-detectable particulate matter emissions and less carbon dioxide than other fossil fuels.

- Mine safety. Coalbed methane poses a safety hazard (i.e., potential for explosions) for coal mining operations. Recovery of coalbed methane significantly reduces this hazard.

However, there are several hurdles to coalbed methane recovery and use. These include:

- Cost competitiveness. Significant costs are associated with exploration, production, gathering, upgrading, transporting and using coalbed methane. Unless significant quantities of methane are expected, and markets are willing and able to pay for the methane (or electricity or heat from the methane), the economics may not justify recovery.

- Ownership. Determining the rightful owner of the methane gas can be complicated. Surface land owners, coal mine owners, gas producers, mineral rights owners, governments and others may claim rights to the gas. In most countries, ownership issues have not been resolved.

- Changing mind-sets. The coal industry is not in the gas business. Effort must be made to show the coal industry the safety, economic and environmental advantages that could result from methane recovery and utilization. 


\subsection{Small-Scale Fluidized-Bed Combustion}

Fluidized-bed combustion (FBC) is a well-proven technology for industrial and electric utility applications. Hundreds. of FBCs, supplied by many equipment vendors, are in operation in the U.S. and other parts of the World. However, in Alaska, and potentially in many other remote locations in the World, very small - less than $10 \mathrm{MW}$ (down to below $1 \mathrm{MW}$ ) - units are needed to meet local energy needs. Very little operational experience is available for FBC units of this size.

FBCs have many attributes that may make them very suitable for remote locations. These include:

- Fuel flexibility. FBCs have been successfully operated on a wide range of fuels and fuel combinations including all grades and ranks of coal, anthracite culm, wood, municipal solid waste, heavy oil and tires, among others. The technology is quite tolerant to variations in fuel quality, an important feature in remote locations where quality controls on fuel are likely to be lacking.

- Configuration flexibility. FBCs can be configured to cogenerate electricity and heat, significantly improving its thermal efficiency and in many cases reducing the cost of supplied energy.

- Ease of operation and maintenance. FBCs are relatively easy to operate and maintain. There are no special fuel handling requirements for FBCs. Because of its low combustion temperatures, solids deposition and boiler tube erosion/corrosion are minimized. The waste produced in an FBC boiler is dry, inert and relatively easy to handle.

- Environmental. FBCs can produce energy efficiently and with minimal environmental emissions. Because of their low operating temperatures, $\mathrm{FBCs}$ produce low levels of nitrogen oxides $\left(\mathrm{NO}_{\mathrm{x}}\right)$. If lime or limestone is added to the combustor, sulfur dioxide $\left(\mathrm{SO}_{2}\right)$ emissions can be reduced by $90 \%$ or more. The dry wastes from the system are inert and can be used for road and building materials, or possibly as fertilizer.

However, there are several concerns associated with the use of small FBCs for use in remote applications. These include:

- High capital cost. FBCs can carry higher capital costs than diesel generators or current natural gas based systems (gas turbines or combined cycle). In many cases, even with higher capital costs, FBCs can produce electricity at competitive rates, because of low fuel costs.

- Operation and maintenance. Although FBCs can operate fairly "hands free", they requires trained operators to assure that 1) the fuel is properly fed, 2) the unit is operated and maintained appropriately, and 3) the waste is properly handled. FBCs may require operators with greater training than natural gas or diesel-fueled systems.

- Waste production. A considerable quantity of solid waste is produced in FBCs, especially if lime or limestone are added for $\mathrm{SO}_{2}$ control. Although the waste is benign and possibly of commercial value, periodically it must be removed from the boiler site and transported to a disposal or end-use site. 


\subsection{Coatfired Diesels}

Coal-fired diesel engines have been under development for approximately 15 years. Several technology configurations have been explored to displace petroleum with coal for transportation applications (e.g., coal-fired locomotives), cogeneration systems and electric power systems. None of these systems are currently offered commercially, although one has been selected under the Department of Energy's Clean Coal Technology Program to demonstrate the engine for cogeneration applications.

Coal-fired diesels (CFD) have several attributes that may make them attractive for remote power applications. These include:

- Fuel Cost. CFDs use low cost coal rather than high-cost diesel fuel.

- Environmental. CFDs have the potential to reduce emissions of particulate matter and other harmful air pollutants associated with the combustion of diesel fuel.

- Fuel Availability. CFDs have the ability to use abundant coal resources in lieu of more scarce diesel fuel.

- Operation and Maintenance. As curtently conceived, coal-fired diesels will be as easy to operate and maintain as diesel oil generators.

However, several barriers may impede the ability of coal-fired diesels to meet its market potential. These include:

- Current stage of development. Before coal-fired diesels will be considered in the commercial market, adequate demonstration of their reliability and performance is necessary.

- Fuel Preparation. The ability to produce ultra-clean coal water siurries at reasonable prices to use as a fuel for the system is uncertain, particularly in remote areas.

- Fuel Cost. The cost-competitiveness of coal-fired diesels compared with natural gas and diesel fuel depends on relative economics in the area of use. 


\subsection{FACTORS INFLUENCING THE MARKET POTENTIAL OF REMOTE POWER TECHNOLOGIES}

Summarized below are some factors that are likely to influence the market potential for the three technologies being examined for remote applications in developing countries.

\subsection{Coalbed Methane}

The primary factors that will influence the market potential for coalbed methane are:

- The number of small remote communities that are isolated from central station electric supplies, natural gas or other potentially lower cost energy options.

- The size of end-use markets located close to the coalbed methane or the proximity of natural gas pipelines.

- Resolution of gas ownership issues.

- The economic viability of exploring, drilling, recovering, gathering, cleaning, transporting and utilizing the coalbed methane.

\subsection{Small Scale Fluidized Bed Combustors}

Several factors will influence the market potential for small FBCs. These include:

- The number of small remote communities that are isolated from central station electric supplies, natural gas or other potentially lower cost energy options.

- The proximity of low-cost coal to the FBC site. The further the FBC site is from the coal, the higher the costs. Low fuel cost is the principle economic advantage of FBCs.

- The willingness of technology suppliers to offer commercial guarantees for the FBCs.

\subsection{Coal-fired Diesels}

The primary factors that will influence the market potential for coal-fired diesels are:

- The number of small, remote communities that are isolated from central station electric supplies, natural gas or other potentially lower-cost energy options.

- The extent to which diesel-fueled generators are currently used to meet electricity and heat needs.

- The proximity to coals that can be economically cleaned to very low ash levels (i.e., $1 \%$ or less).

- The availability of water for producing coal/water mixtures as the feedstock to the coal-fired diesel generators. 
- The willingness of technology suppliers to offer commercial guarantees for the coal-fired diesel systems.

In Sections 3 and 4, these factors are examined to the extent that data are readily available and project resources permit. 


\subsection{COALBED METHANE RECOVERY AND USE}

\subsection{Global Prospects}

It is estimated that between 4,000 and 9,000 trillion cubic feet (TCF) of coalbed methare (CBM) resources exist throughout the World (USEPA, 1993). These resources consist of methane found in both unmined coal and coal that has been or is being mined. To put this figure in perspective, the U.S. - one of the major consumers of natural gas - consumes approximately 18 TCF of natural gas annually. If the full potential of worldwide coalbed methane is recognized, it could supply current U.S. natural gas demand for over 300 years.

The countries with the largest coalbed methane reserves include:

\begin{tabular}{cc} 
Country & Estimated Reserves \\
\cline { 2 - 2 } Russia & $600-4,000$ \\
China & $1,000-1,200$ \\
United States & 400 \\
Ukraine & 60 \\
Poland & $20-45$ \\
Kazakhstan & 40 \\
India & 30 \\
South Africa & 30
\end{tabular}

During mining, considerable quantities of coalbed methane are released to the atmosphere. It is estimated that 1-2 TCF of coalbed methane is released to the atmosphere worldwide. This has become a major environmental issue since methane is a very reactive greenhouse gas, 21 times more effective at trapping heat in the atmosphere as carbon dioxide $\left(\mathrm{CO}_{2}\right)$. As a result, attention has been placed on minimizing these releases through capture and utilization.

The potential exists to recover some of the coalbed methane released to the atmosphere. However, it is unlikely that, with current technology and at current energy prices, all of these emissions are recoverable (Coal Industry Advisory Board, 1993). In addition, it is possible to recover methane that is located in unmined coal seams. However, because of lack of data, the latter source of coalbed methane was not fully analyzed in this report.

It is estimated that $25-45 \%$ of these reserves are recoverable. In 1990, some of the World's leading coal producers recovered $20 \%$, but only utilized $7 \%$, of the coalbed methane released at that time. In many countries, even less recovery and utilization has taken place. Table 3-1 summarizes CBM emissions by major emitting country, the amount of coalbed methane that was recovered in those countries and the potential recovery possible in the near term (USEPA, 1993).

\subsection{Potential in Remote Regions}

The market potential for coalbed methane to meet the energy needs of remote regions throughout the World is dependent on 1) the proximity of the methane to the remote communities, 2) access of the remote communities to other, possibly lower cost energy options, and 3) the economic viability of exploring, drilling, recovering, cleaning, gathering, transporting and utilizing the fuel versus other options. Each of these factors is discussed in the following paragraphs. 
TABLE 3-1

CBM RECOVERY POTENTIAL IN

COUNTRIES WITH LARGEST COALBED METHANE RESOURCES

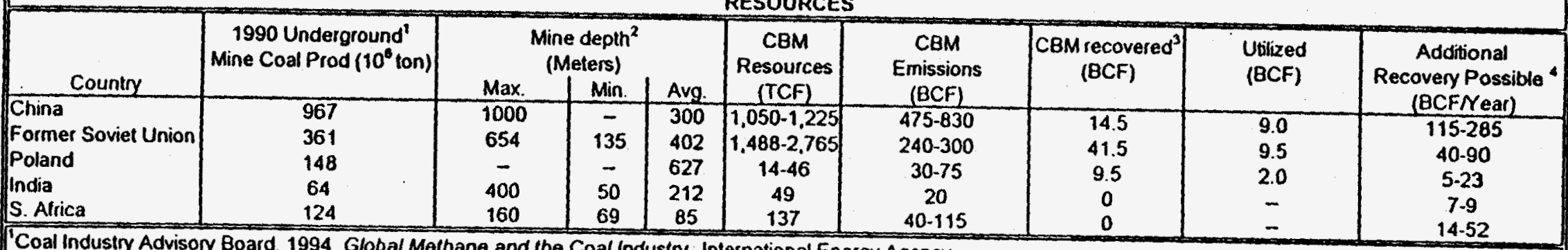

Coal Industry Advisory Board, 1994. Global Methane and the Coal Industry, international Energy Agency.

${ }^{2}$ Kuchgessner, D.G., S.D. Piccot, J.D. Winkler, 1994, Estimale of Global Mothane Emissions from Coal Mines. U.S. Environmental Protection Agency.

3 U.S. Environmental Protection Agency, 1993. Options of Reducing Methene Emissions internationally, Volume II: Intemetional Opportunities for Raducing Methane Emission, Report to Congress, (October).

- Assumes $25.35 \%$ recovery in China/Poland: $20.25 \%$ in CIS: $35-45 \%$ in India/S. Africa. 
Several of the countries with the largest coalbed methane reserves are also among the most populated in the World. China and India rank 1 and 2 in population, respectively. Russia has the 6th largest population in the World. Table 3-2 summarizes the populations of each of the countries studied and their World rank.

In most of these countries, a considerable percentage of the population reside in rural areas, isolated from electricity. Table 3-2 provides information on the percentage of the population for each country that is located in rural areas. As can be seen, China and India have rural populations approaching $80 \%$ of their total population. The countries of the Former Soviet Union average $36 \%$ rural. In South Africa and Poland $40 \%$ of the population is located in rural areas.

In addition, many of the residents of these countries currently do not use electricity, or do not have access to it. Table 3-2 provides information on the electrification ratio in those countries where data exists. The electrification ratio - the percentage of the population having no access to electricity - is another indicator of remoteness. Those without access to electricity are prime markets for on-site electricity produced from coalbed methane.

\subsection{Country Assessments}

\subsubsection{Russia}

\subsubsection{Population and Land Use}

Russia, with a population of 149 million, is the most populated of the Former Soviet Union (FSU) States, and the sixth most populated country in the World. Approximately $25 \%$ of its population is rural. Thirteen cities in Russia have a population in excess of one million.

Most of the population of Russia is concentrated in the so-called fertile triangle (European Russia), with its base along the western border between the Baltic and Black Seas and which tapers eastward across the southern Urals into southwestern Siberia (Figure 3-1). In this region, the population density averages 65 persons per square mile, although it is much higher in urbanized areas such as the Moscow Oblast. Figure 3-2 shows the population densities throughout the Former Soviet Union.

More than one-third of the country's territory has fewer than 2.6 inhabitants per square mile. This region comprises northern European Russia and huge areas of Siberia.

Russia has the largest land area of any country in the World. The country has six major land regions. These are briefly described below and are shown in Figure 3-1.

(1) The European Plain. This is home to approximately three quarters of Russia's inhabitants. Most of the Nation's industries and most of its richest soils are located in this region. The Ukraine is located in this region.

(2) The Ural Mountains form a boundary between the European Plain and Siberia. The middle section is the most heavily populated section of the region.

(3) The Aral-Caspian Lowland, has broad sandy deserts and low grassy plateaus and is sparsely populated; it includes most of Kazakhstan. 
TABLE 3-2

POPULATION CHARACTERISTICS IN

COUNTRIES WITH LARGEST COALBED METHANE RESOURCES

\begin{tabular}{|c|c|c|c|c|c|c|}
\hline Country & $\begin{array}{c}1993 \\
\text { Population } \\
\end{array}$ & $\begin{array}{c}\text { Population } \\
\text { Rank }^{1}\end{array}$ & $\begin{array}{l}\text { Population Density } \\
\text { (per square mile) }\end{array}$ & $\begin{array}{l}\% \text { of Population } \\
\text { In Rural Areas } \\
\end{array}$ & $\begin{array}{l}\text { Electricity Consumption } \\
\text { per Capila (1992) (kWh) }{ }^{4,5}\end{array}$ & $\begin{array}{c}\text { Electrification ratio } \\
\text { (\% with access to electricity) }\end{array}$ \\
\hline China & 1,205 & 1 & 319 & 79 & 630 & $66^{2}$ \\
\hline India & 897 & 2 & 275 & 77 & 340 & $55^{2}$ \\
\hline Kazakhstan & 17 & Top 75 & Unknown & 40 & 4.739 & $80-95^{7}$ \\
\hline Poland & 39 & Top 40 & 314 & 40 & 3.570 & $95^{7}$ \\
\hline Russia & 149 & 6 & 23 & 25 & 6.782 & $95^{7}$ \\
\hline South Africa & $\begin{array}{l}41 \\
52\end{array}$ & Top 40 & $\begin{array}{c}74 \\
\text { Unknown }\end{array}$ & $\begin{array}{l}40 \\
33\end{array}$ & 4,100 & $35^{6}$ \\
\hline Ukraine & 52 & Top 25 & Unknown & 33 & 5.410 & Unknown \\
\hline
\end{tabular}

'Energy Informalion Administration, 1995. Intemational Energy Annual 1993. U.S. Department of Energy, DOE/EIA-0219 (93) (May).

'World Bank, 1994, Power Sector Statistics for Developing Countries, 1987-1991.

WWorld Bank, Inc., 1986, The World Bank Atlas.

4 World Book, Inc., The World Book Encyclopedia, 1988 Edition.

I In contrast, US per capita electricity consumption is $12,690 \mathrm{kWh}$.

'Surridge \& Grabbelaar, 1994, Energy Republic of South Africa: The Gas Connection, (September).

Estimales 

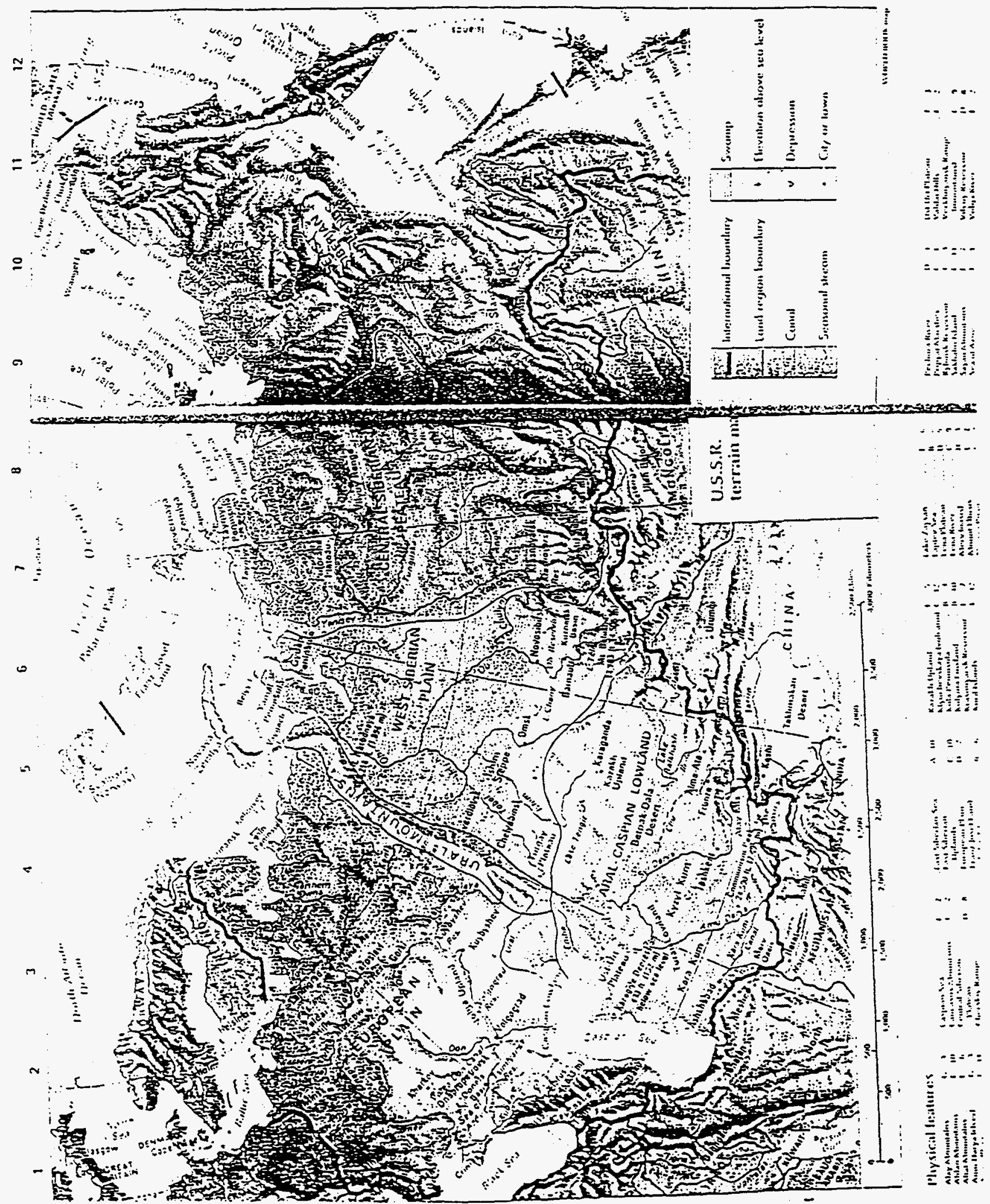

FIGURE 3-1. Map of Russia 


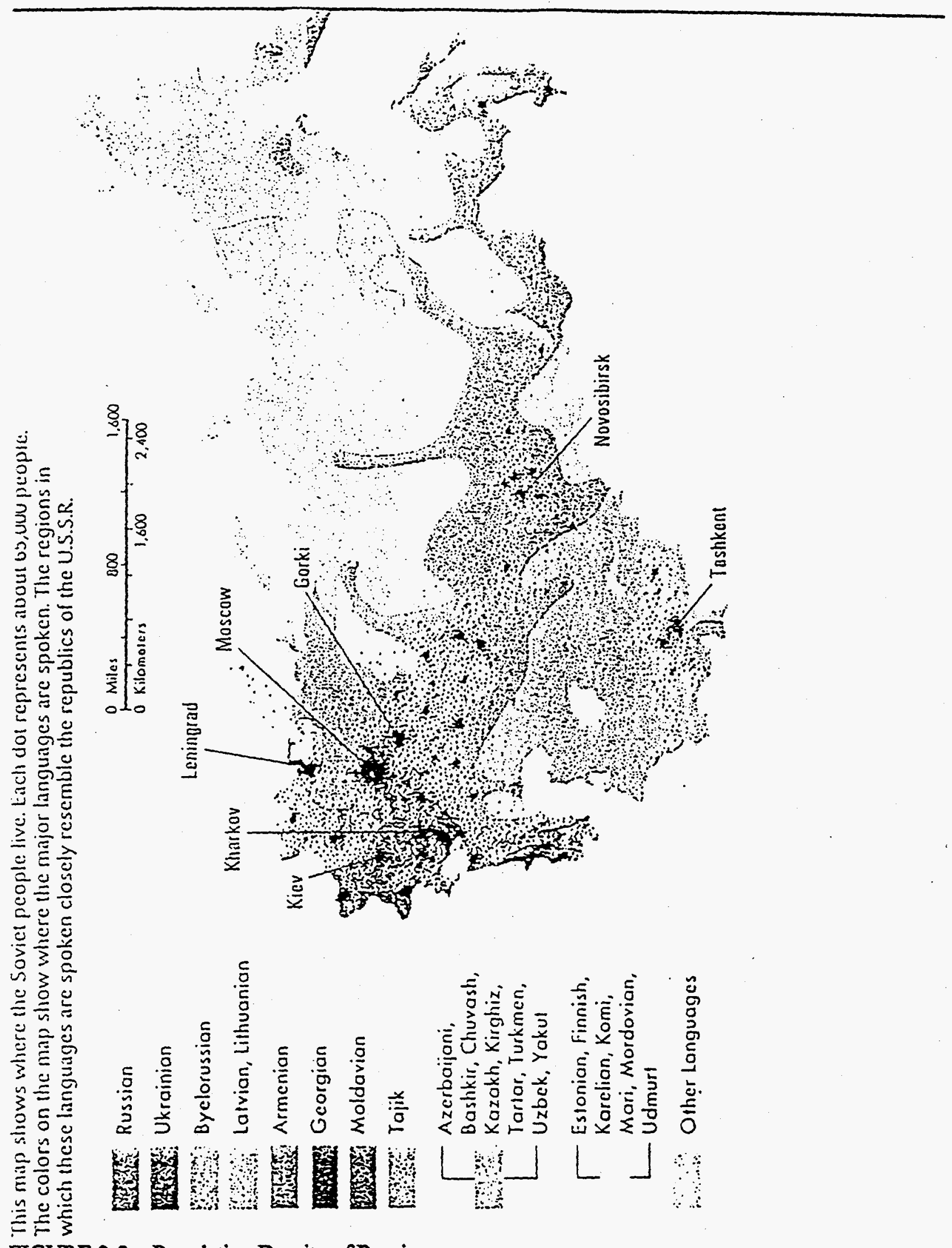

FIGURE 3-2. Population Density of Russia 
(4) The Western Siberian Plain lies north of the Altai Mountains and is the largest level region of the World. This also is a sparsely populated region.

(5) The Central Siberian Plateau, a very sparsely populated region, where tremendous coal reserves lie.

(6) The Eastern Siberian Uplands are mainly a wilderness of mountains and plateaus. This region is rich in oil and gas resources.

\subsubsection{Energy Resources}

Russia is one of the richest countries in the World in terms of energy. Coal, natural gas and other energy resources are prevalent throughout Russia. In 1993, natural gas reserves in Russia were estimated to be 1,748 TCF.

In 1994, Russia produced 18.9 TCF of natural gas, 307 million tons of coal, and 6 million bartels of oil. It consumed (in 1992) 14.7 TCF of gas, 309 million tons of coal, and 3.2 million barrels of oil. Its electric generating capacity is estimated to be $213 \mathrm{GW}$.

Natural gas production and consumption in Russia are the largest in the World. Ninety percent of the natural gas production in Russia is currently taking place in Westem Siberia (USDOE, 1994a). As production in existing fields declines, exploration and development is focusing in the Yamal Peninsula in the far northern part of the West Siberian Plain. Most of the future natural gas exploration and production is expected to take place in the far eastern reaches of Siberia.

Gazprom, the state-owned operator of Russia's 100 largest gas fields, administers 86,000 miles of gas pipelines, mainly located within Russia. Although initially intended for export to Europe, it is anticipated that much of the gas produced in Russia will be used domestically (because of difficulties in building pipelines).

Russia is also a major producer and consumer of coal. In 1993, it produced 307 million tons of coal and consumed approximately 309 million tons (USDOE, 1995). Approximately 220 million tons of hard coal were consumed in Russia in 1993. Figure 3-3 shows the locations of the major hard coal basins in Russia.

The largest coal basin in Russia is the Kuznetsk Basin in the Western Siberian Plain region. Approximately 53 million tons of coal were produced from this basin in 1994 (USEPA, 1995). It contains an estimated 637 billion tons of coal and produces high quality bituminous coal, mostly from underground mines. It has high potential for coalbed methane production. Other regions rich in hard coal include:

- the vast Tunguska Basin in the Central Siberian Plateau;

- the Taymyr Basin in the northern section of the Central Siberian Plateau

- the Pechora Basin in the far northeastern region of the European Plain, and

- potentially coal basins in Siberia. 


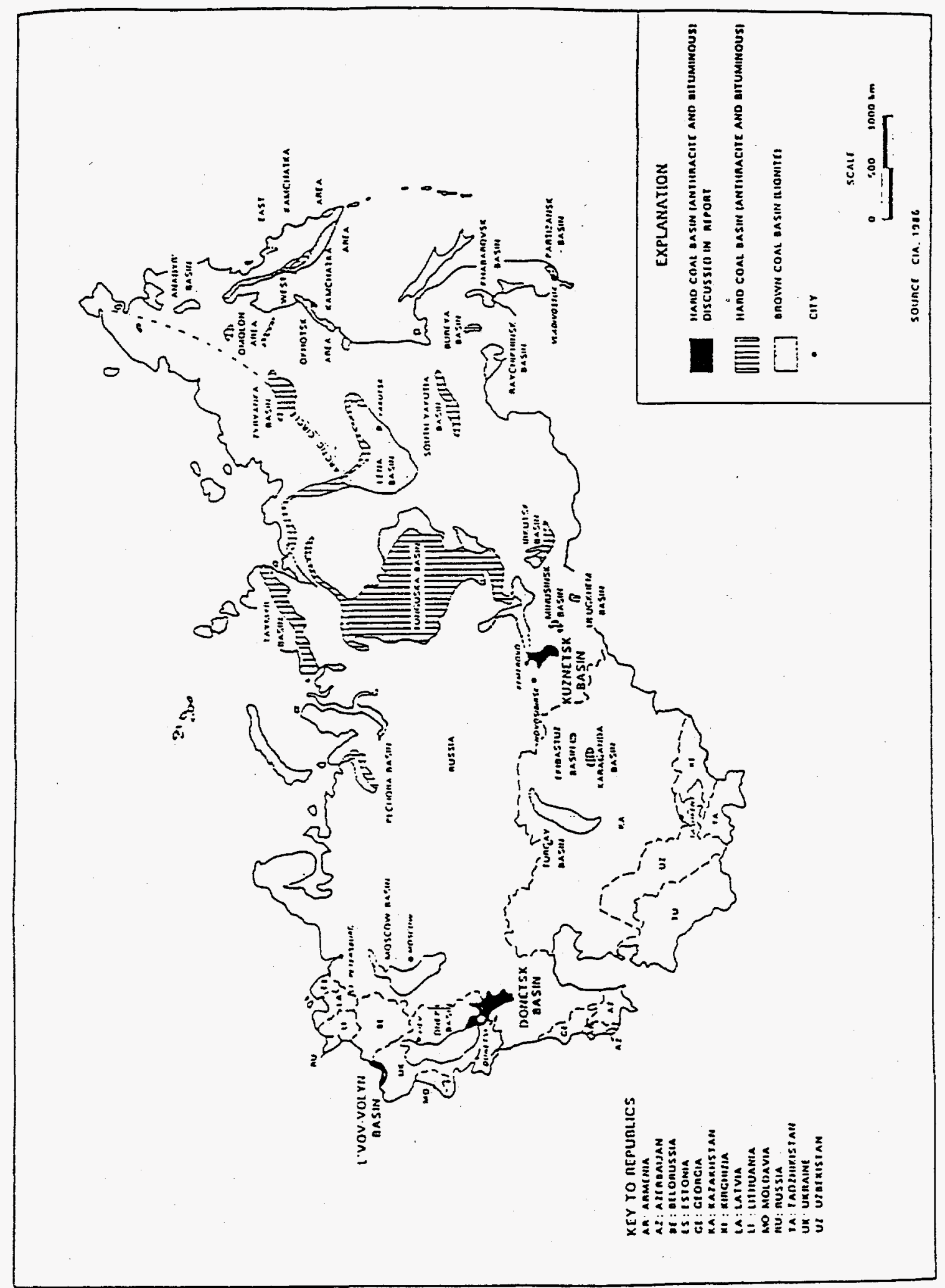

FIGURE 3-3. Major Coal Basins of the Former Soviet Union 


\subsubsection{Coalbed Methane Recovery Potential}

The coalbed methane resources in Russia are estimated to be between 1,488 and 2,765 TCF, the largest in the World (USEPA, 1995). It is estimated that the coalbed methane potential of the Kuznetsk Basin alone is 7-12 TCF per year. Parts of the region are industrialized, creating opportunities for near-by markets to utilize captured coalbed methane. The region consumes large quantities of imported (to the region) natural gas (estimated to be 5 billion cubic feet per year), only one-third of its demand. Although precise gas pipeline maps were not available for this study, it appears as though gas pipelines run near the Kuznetsk Basin bringing gas from Westem Siberia to Novosibirsk, to the northwest of the Basin.

The Pechora Basin, located in northern Russia, also has significant methane potential because large quantities of hard coal are mined there. However, since most of the Basin is above the Arctic Circle, the climate conditions may be so harsh that recovering the methane will not likely be cost-effective.

The vast Tunguska Basin also appears to have great potential for coalbed methane recovery, although no information could be found that characterizes the resource. However, since most of the coal produced in this region is from underground hard coal mines, large quantities of coalbed methane are likely. Since this Basin is also a major gas producing region, although it is isolated from significant population centers, limited pipeline capacity may be close enough to the coalbed methane to consider transporting it to markets outside of the region.

Other hard coal deposits are scattered throughout the Pechora and Taymyh Basins in north central Russia and several other Basins in eastern Russia. These too have the potential for coalbed methane.

\subsubsection{Potential Applications for Coalbed Methane In Russia}

Several market opportunities exist for coalbed methane in Russia. These include:

- Clean and efficient feedstock for boilers used to provide heat for the coal mines. Currently, large quantities of unwashed coal are being used in the Kuznetsk Coal Basin for such purposes in uncontrolled boilers (USEPA, 1995). A typical Kuzbass mine may consume 50,000 to 700,000 tons of coal per year in its boilers. More than $40 \%$ of the industrial coal consumed in this region is for this purpose. Diesel fuel is used to provide heat and electricity to those mines not using coal. Although no information is available for the other coal basins, it is expected that similar opportunities exist in other coal mines as well.

- Fuel for furnaces used in the metallurgical industry. Currently $69 \%$ of this need is being satisfied by natural gas and $25 \%$ by wood. Coalbed methane may offer a lower cost option to natural gas and a more environmentally acceptable option than wood. Kuzbass coal mines are located in close proximity to large iron and steel complexes in the region. Other regions of Russia may afford similar opportunities.

- Fuel for power generation at mine facilities. Currently, most mines in the Kuzbass purchase electricity from the power grid. Coalbed methane, used in simple or combined cycle mode, may offer a more economic and environmentally acceptable option to the use of electricity produced from coal in central power stations. Similar opporturities are likely in other regions of Russia as well. 


\subsubsection{Ukraine}

\subsubsection{Population and Land Use}

The Ukraine, with a population of approximately 52 million, is among the 25 most populated countries in the World. Approximately one-third of its population is rural. The population density is moderate; on average, approximately 50 to 100 people inhabit each square mile (Nystrom Desk Atlas, 1994). Its most populated cities include:

- Kharkiv (1.6 million)

- Dnipropetrovk (1.2 million)

- Donetsk (1.1 million)

- Odesa (1.1 million)

- L'viv $(800,000)$

Ukraine is a vast plain with very rich soil. Most of the country is used for agricultural purposes with the exception of the large cities and southern Ukraine which contain a variety of manufacturing facilities.

\subsubsection{Energy Resources}

Natural gas dominates the fuel mix in Ukraine. In 1992, gas represented $42 \%$ (4 TCF) of the energy consumed there. Coal (29\%), nuclear $(9 \%)$, and oil (19\%) make up the rest of the energy consumed by the Ukraine in 1992.

Ukraine is also a major producer of natural gas, although it must import large quantities from Russia. In 1992, it produced 735 BCF of gas. Coal consumption in Ukraine in 1992 was 130 million tons; it produced 127 million tons.

Ukraine has an abundance of coal primarily found in two basins - the Donetsk and LLov-Volyn Basins (see Figure 3-3). It is estimated that the reserves in the Donetsk Basin are over 140 billion tons; those of the LLov-Volyn Basin are estimated to be just over 2 billion tons. Both Basins produce hard coal (anthracite and bituminous) from deep mines (USEPA, 1995).

Hard coal produced from the Ukraine portion of the Donetsk Basin (coal is also produced from this Basin by Russia) was nearly 130 million tons in 1991. This represents approximately $93 \%$ of the total hard coal production in Ukraine (USEPA, 1995).

\subsubsection{Coalbed Methane Recovery Potential}

The coalbed methane resources in the Ukraine are estimated to be $60 \mathrm{TCF}$. Almost $160 \mathrm{BCF}$ of coalbed methane was released in 1991; most of this methane (nearly $120 \mathrm{BCF}$ ) was liberated from coal mining operations in the Donetsk Basin. Of the 160 BCF liberated, only 28 BCF (17\%) was captured and $6 \mathrm{BCF}(4 \%)$ was used (exclusively in boilers at the mines). The Donetsk Basin region is heavily industrialized. Therefore, many opportunities exist for the use of captured coalbed methane in nearby operations. 
The LVov-Volyn Basin located in western Ukraine, is the southeastern extension of the Lubin Coal Basin in Poland. The total coal reserves of the Basin are estimated to be 2.1 billion tons; in 1991, coal production was 9.5 million tons. It is estimated that 5.3 BCF of methane were released from mines in the L'Vov-Volyn Basin during 1991. Only $4 \%$ was captured, none of the methane was utilized.

It is estimated that if $35-45 \%$ of the coalbed methane released to the atmosphere in Ukraine is captured and utilized, an additional 14 to 52 BCF of methane could be recovered. Additional recovery from unmined reserves is also possible.

\subsubsection{Potential Applications for Coalbed Methane in the Ukraine}

As in Russia market opportunities to use captured coalbed methane include the displacement of coal in industrial boilers and powerplants at coal mines, to produce heat and electricity needed at the mines. In addition, because Donetsk is located in a heavily industrialized region methane from its mines can be used in machine factories, petrochemical plants, and metallurgical factories.

Because Donetsk is heavily industrialized, it has access to natural gas delivered by an extensive network of pipelines (Figure 3-4). As a result, it may be possible to use captured coalbed methane for many other applications by transporting it to end users by pipeline. However, as is discussed later in this report, doing so may be cost prohibitive.

Since the LVov-Volyn Basin is located within an agricultural region, methane captured from coal mining there will, most likely, be most cost-effectively utilized for meeting energy needs at the mines.

\subsubsection{Barriers to the Recovery and Use of Coalbed Methane in Russia and Ukraine}

Although coalbed methane is readily available in Russia and Ukraine - and has large market potential its recovery faces several serious hurdles. These include:

- the unstable Russian legal and financial environment will make it difficult to finance such projects.

- high taxes and other costs of doing business in Russia may be prohibitively expensive.

In addition, piping coalbed methane through the extensive network of natural gas pipelines may be cost prohibitive. Pipeline quality gas must be more than $95 \%$ methane. However, coalbed methane recovered in Russia and the Ukraine typically has methane concentrations ranging from 30 to 50 percent (USEPA, 1995). Therefore, to transport the gas in pipelines, it must be enriched. In the U.S., enriching coalbed methane from $70-80 \%$ methane to pipeline quality is expensive, costing in the range of $\$ .01$ - \$.09/cubic meter. Enriching the much lower concentrated Russian and Ukrainian gas is expected to be considerably more expensive.

\subsubsection{South Africa}

\subsubsection{Population and Land Use}

South Africa has a population of approximately 35 million. Approximately $60 \%$ of the people in South Africa live in urban areas, even though only three cities in the country have populations in excess of 500,000 (i.e., Cape Town, Johannesburg and Durban). Twenty-five percent of the population lives within a 43 mile radius of Johannesburg (World Book, 1988). 


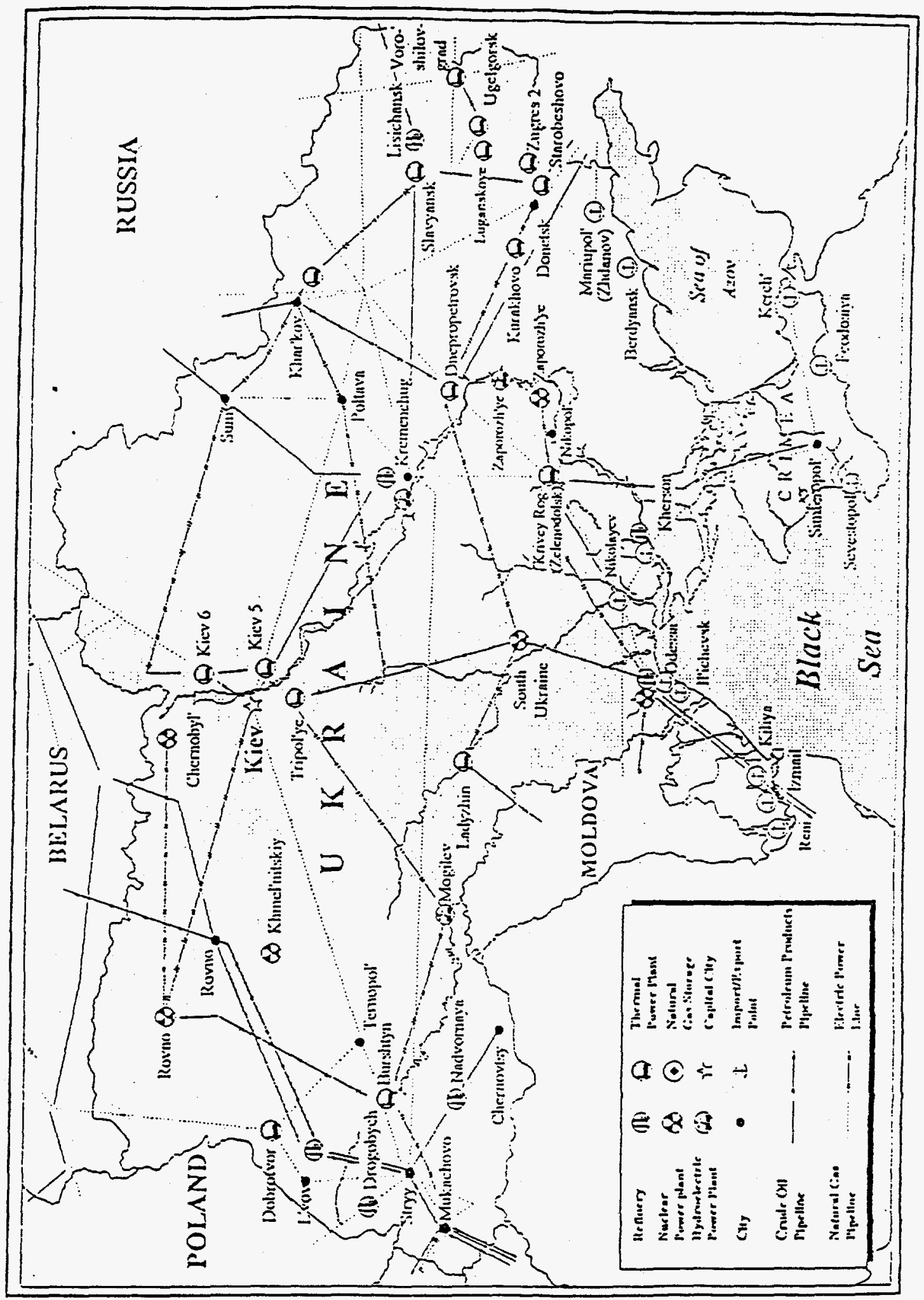

FIGURE 3-4. Transmission Network and Power Plants in the Ukraine 
Although South Africa contains only $6 \%$ of the African continent's population and $4 \%$ of the continent's land area, it produces $40 \%$ of Africa's manufactured goods, half of its minerals, and half of the continent's electricity (World Book, 1988).

South Africa lands are used for a variety of applications (Figure 3-5). The Plateau, the largest land area, is the chief industrial and business area in South Africa. Middleveld in the Northwest, is sparsely populated ranch lands. The Coastal Strip is mainly agricultural with the exception of the land in the immediate proximity of Durban, which is an industrial center.

\subsubsection{Energy Resources}

South Africa is largely dependent upon coal as its primary energy source. In 1992, coal provided $82 \%$ of the primary energy in South Africa, followed by crude oil and biomass (e.g., wood) at $9 \%$ and $6 \%$, res: tively (Surridge \&Grabbelaar, 1994). Biomass is mainly used in the rural sector for domestic heating and cooking.

In 1992, South African coal sales totalled 176 million tons. Twenty eight percent of the coal produced in South Africa was exported, 39\% was used for electricity production, $16 \%$ for conversion to liquid fuels, $10 \%$ for commerce and industry and the remainder for metallurgy, and mining (Surridge \& Grabbelaar, 1994).

The gas consumed in South Africa for commerce, industry and households is derived from coal. There are three main sources of natural gas available to South Africa:

- The Pande gas field, an offshore field with estimated recoverable reserves of 1.75 to $2.8 \mathrm{TCF}$. Use of this gas would require the construction of a $900 \mathrm{~km}$ pipeline.

- The Kudu gas field offshore Namibia; with estimated reserves of 3 to 8 TCF. Use of this gas would require development of the resource and construction of a $600 \mathrm{~km}$ pipeline.

- Production from the natural gas field in South Africa, Mossgas. It is located $93 \mathrm{~km}$ from the mainland and has reserves estimated to be $700 \mathrm{BCF}$.

In 1989, South Africa produced over $160,000 \mathrm{GWh}$ of electricity from its $37 \mathrm{GW}$ of capacity. Approximately $92 \%$ of the generation was supplied by coal (Surridge \& Grabbelaar, 1994). Among the 40 million inhabitants in South Africa, only $35 \%$ are electrified. The remainder of those without electricity and who do have access to electricity use wood and coal, primarily for cooking.

\subsubsection{Coalbed Methane Recovery Opportunities}

South Africa has demonstrated coal reserves of over 120 billion tons (Industrial \& Petrochemical Consultants, 1991). Figure 3-6 shows the locations of the major coal fields in South Africa. The most important coal region is the Karoo Basin, which has demonstrated reserves of approximately 60 billion tons.

It is estimated that South Africa has up to 3 TCF of coalbed methane potential; based on current calculations $140 \mathrm{BCF} /$ year of methane is emitted from coal mines, none of which is collected. 


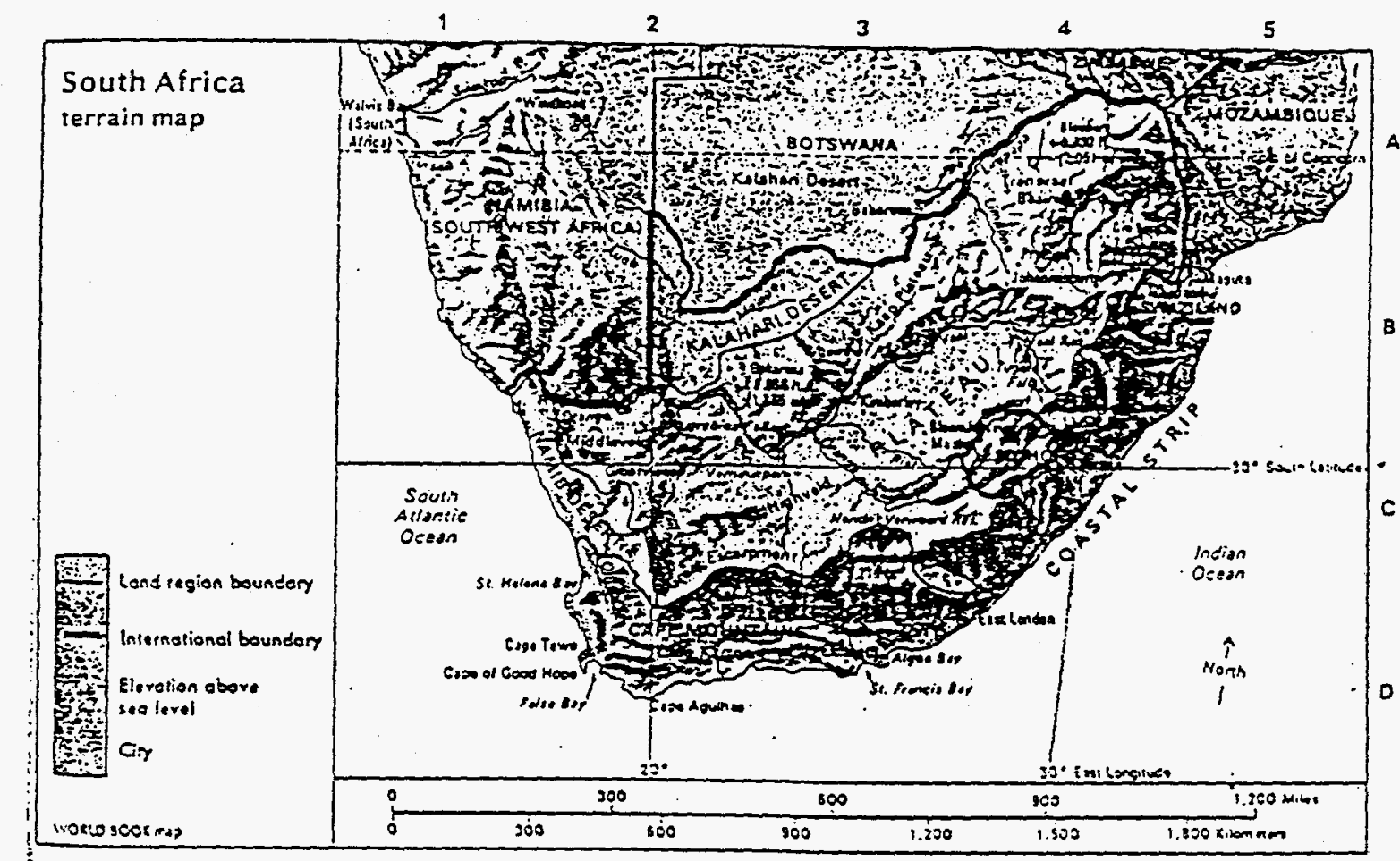

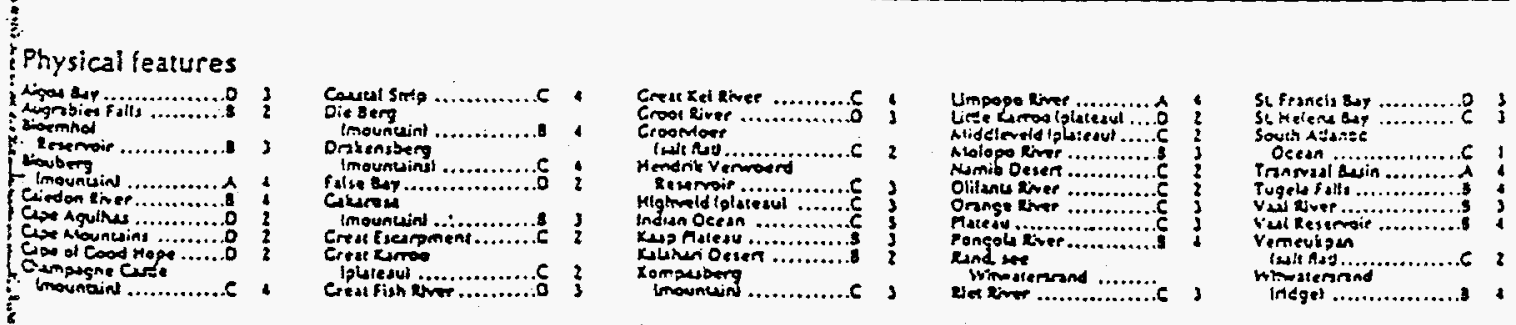

FIGURE 3-5. South Africa: Geographic Regions 


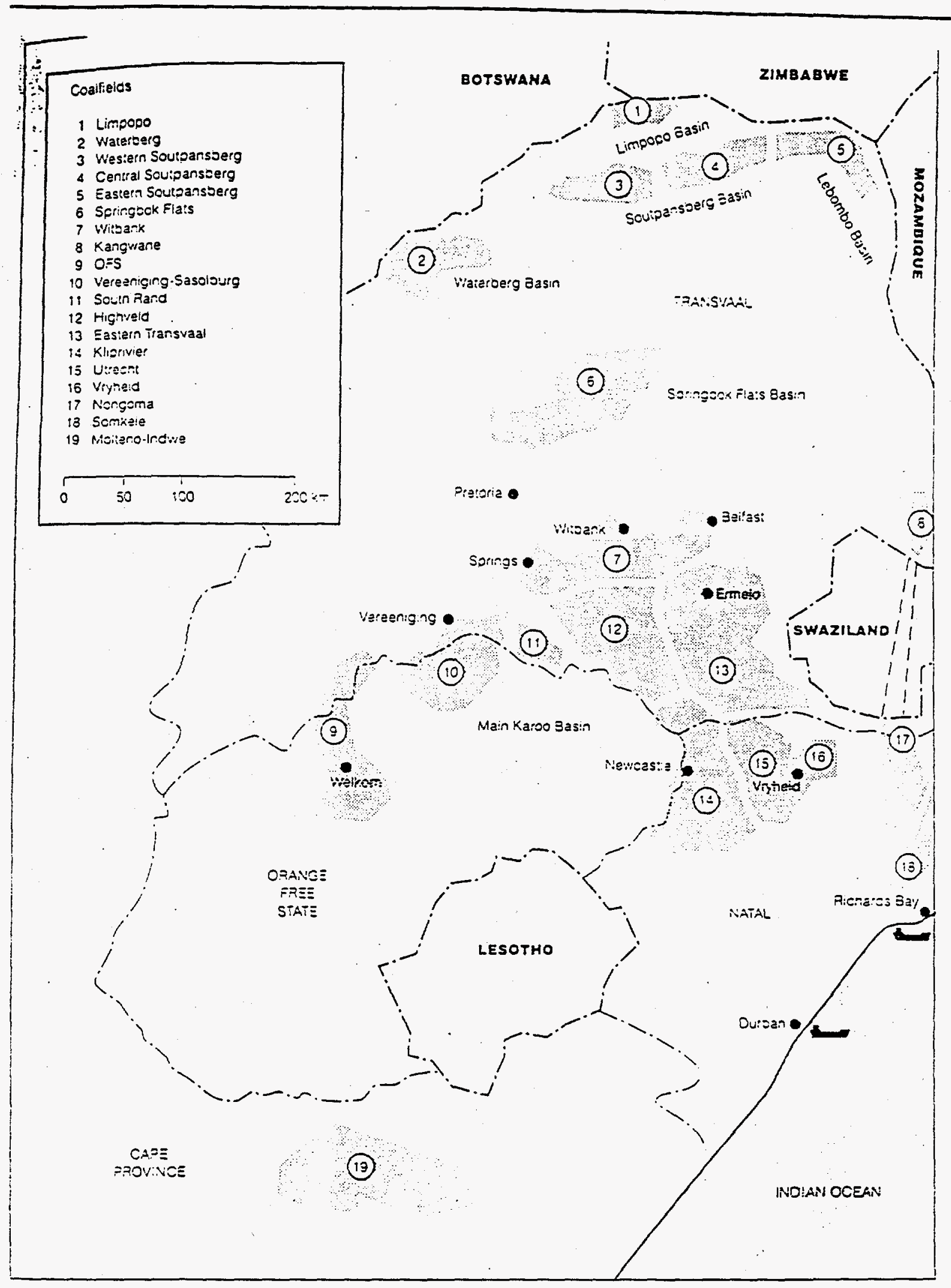

FIGURE 3-6. South Africa: Principal Coal Fields 
Based upon the key factors for determining the coalbed methane potential from coal deposits - coal seam depth (deeper than 150 meters is desirable), high vitranite values, low volatile matter content, and high rank - the following can be concluded:

- Karoo Basin has high potential for coal fields found at depths below 150 meters;

- Orange Fee State Basin is low in potential because it is low in rank;

- Natal has high potential for those coal fields at depths greater than 150 meters;

- Molteno coal field is low in potential because it has high mineral matter content;

- Limpopo, Southpansberg and Sprigbrok Flats regions are low in potential because they are too isolated (and will not be cost-effective to produce and transport) and are faulting coal reserves.

As a result, the most promising areas for coalbed methane are: the Waterberg, Perdekop (Amersfoost) and Vhyheid coal fields.

\subsubsection{Potential Uses for Coalbed Methane}

Several markets are potentially viable for using coalbed methane, if recovered, in South Africa. These include:

- as a replacement fuel for wood and coal in residential stoves.

- as a fuel source for on-site power production from gas turbines, fuel cells, or combustors for villages without access to electricity.

- as a fuel source for meeting the energy needs at coal mines.

- piping the methane (once it is purified) to other markets (e.g., central electric power, industrial) throughout South Africa (although this option suffers from the lack of gas pipelines in the country).

\subsubsection{Barriers to the Development of Coalbed Methane}

Although significant potential exists for the recovery and use of coalbed methane in South Africa, several barriers exist. These include:

- the lack of information on the coalbed methane resource base;

- the lack of experience in recovering and using coalbed methane;

- the capital cost of coalbed methane projects. The cost of exploration, drilling, producing and transporting the methane, and converting end-use equipment to use coalbed methane may be prohibitively expensive. 


\subsubsection{China}

\subsubsection{Population and Land Use}

China is the most populated country in the World. In 1993, its population was estimated to be 1.185 billion. Approximately $80 \%$ of China's population lives in rural regions although its population density - 319 people per square mile - is among the highest of the countries studied in this report. Figure 3-7 provides information on the distribution of China's population by Province (LBL, 1993).

China's population consumes only $630 \mathrm{kWh}$ per capita, one of the lowest in per capita energy consumption in the World. In part, this is due to the fact that a significant percentage of China's population does not have access to electricity (estimated to be as much as one-third of the population).

China's vast land area varies greatly in composition, climate and use from mountainous to flat, mild to cool temperatures, sparsely populated to densely populated. Its large industrial complexes are centered in the north and northeast; although industrial centers are found in and around many of China's heavily populated cities as well (Figure 3-8).

\subsubsection{Energy Resources}

China produces and consumes more coal than any country in the World. In 1994, it produced approximately 1.2 billion tons and is expected to produce 1.4 billion tons by the year 2000 . Almost all of the coal it produces it also consumes. China's coal reserves are estimated to be nearly one trillion tons.

The northern region of China accounts for $94 \%$ of its total coal resources. Approximately $75 \%$ of its total in-place coal reserves are located in three Provinces: Shanxi, Shaanxi and Inner Mongolia. Although a large portion of China's coal reserves are also located in the northwest portion of the country, the region suffers from unexplored reserves, the absence of infrastructure, and large distances from population centers. Figure 3-9 shows the locations of the coal-bearing sediments in China.

Coal satisfies approximately three-quarters of China's primary energy demand. On the other hand, natural gas supplies only $2 \%$ of the demand. In 1993, 595 BCF of natural gas was produced in China, one-half from Sichuan Province. Over $80 \%$ of the natural gas produced in China is consumed in the industrial sector for fertilizer manufacturing and in ammonia plants. Major impediments exist to expand production from the estimated natural gas reserves of 53 TCF. These include natural gas pricing (at below operations costs) and insufficient pipelines and gathering systems.

In 1991, China had $165 \mathrm{GW}$ of electrical capacity; $115 \mathrm{GW}$ was coal-fueled, $40 \mathrm{GW}$ was hydroelectric and $9 \mathrm{GW}$ was oil/gas-fieled. It is estimated that by 2010 , China will have $428 \mathrm{GW}$ of electrical capacity, $294 \mathrm{GW}$ being thermal (almost all of it coal).

Sixty-seven percent of China's energy demand is in the industrial sector (i.e., manufacturing, mining and construction). Twenty-seven percent of the demand is in the domestic sector (i.e., residential, agricultural and commercial). Six percent of the demand is in the transport sector. 


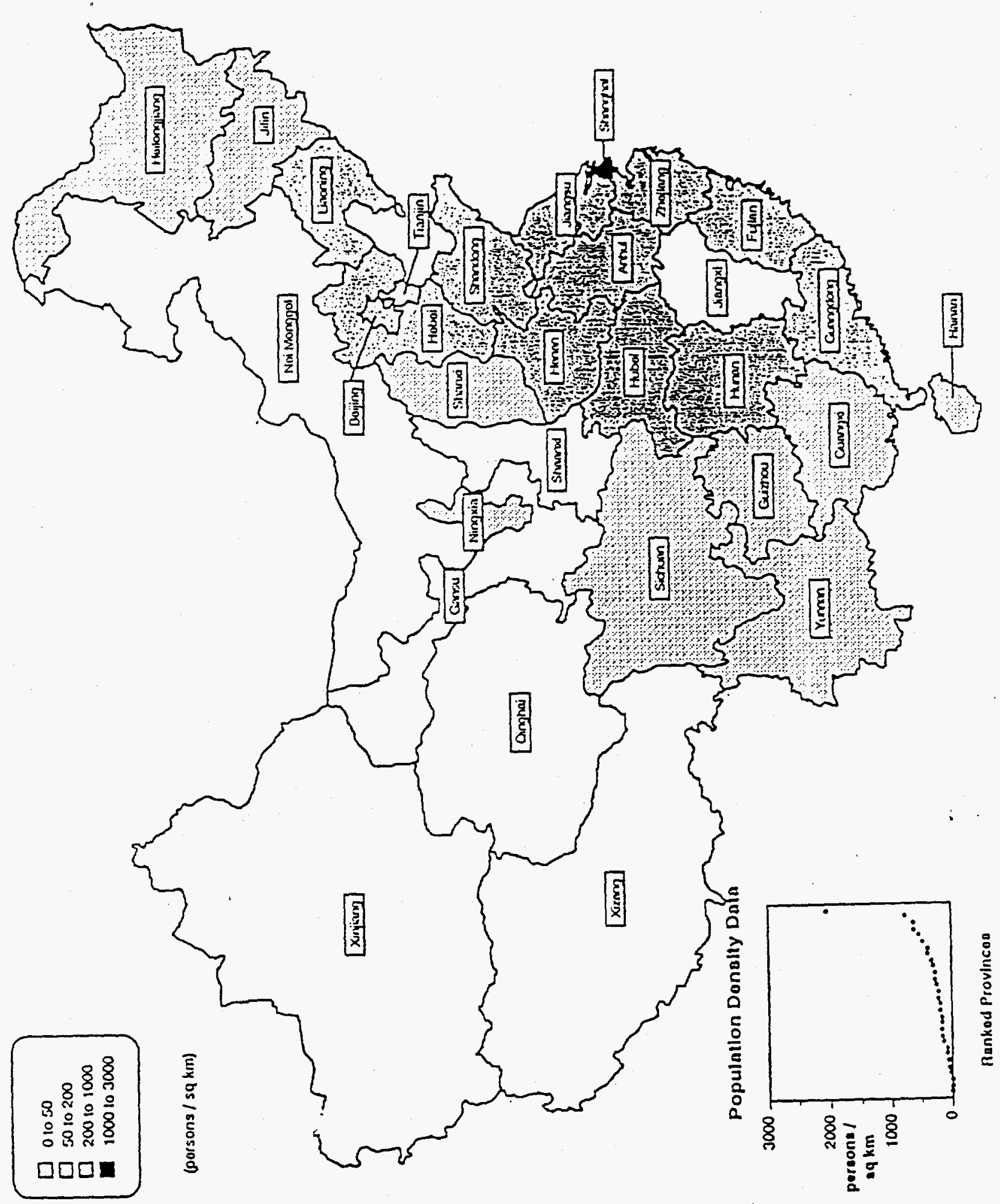

FIGURE 3-7. China: Population Density by Province (1989) 


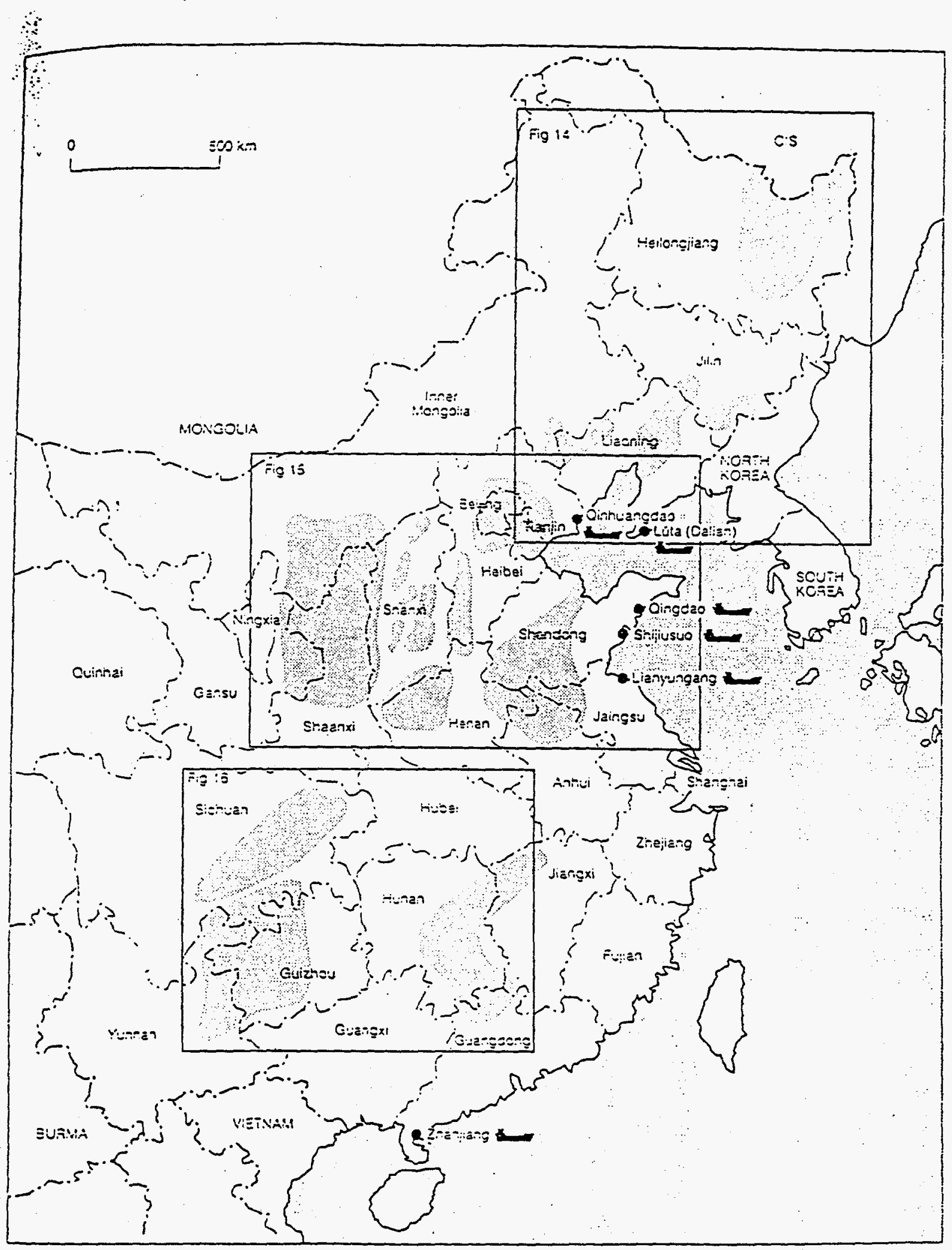

FIGURE 3-9. China: Principal Coal Basins 
China's industrial sector has a fuel mix of $60 \%$ coal, $13 \%$ oil/gas, and $27 \%$ electricity. The largest energy consumers in this sector are the chemical, metallurgical, smelting and building materials industries. Many of China's industrial complexes are located in the northern and northeastern regions of the country, in proximity to the coal producing regions.

China's domestic sector has a fuel mix of $75 \%$ coal, $10 \%$ oil/gas, and $15 \%$ electricity. China's residential fuel consumption is twice that of the commercial and agricultural sectors combined. It is anticipated that there will be substantial growth in energy demand in the residential and commercial sectors, mainly fueled by electricity and possibly gas, if it becomes available at reasonable prices.

China's transportation sector has a fuel mix of $69 \%$ oil/gas, $6 \%$ electricity, and $25 \%$ coal. The rail system in China, consumes approximately one-half of the energy in this sector. This sector consumes most of the coal and electricity used for transportation in China. The International Energy Agency projects that oil demand in China's transportation sector will increase by $7 \%$ per annum, and that coal will be phased out by the year 2010 .

\subsubsection{Coalbed Methane Opportunities}

China's coalbed methane resource is estimated to be between 1,050 and 1,225 TCF (USEPA, 1995b). Figure 3-10 shows the locations of China's coal basins and its estimated coalbed methane resources. As depicted, coalbed methane can be found throughout China with the majority found in its northern regions. Several basins have estimated coalbed methane resources in excess of 35 TCF. Several others have reserves estimated to be between 3.5 and 35 TCF. Many others have reserves of less than 3.5 TCF.

The primary factors influencing the size of the coalbed methane reserves in regions of China are (Coalbed Methane Clearinghouse, 1995):

- Coal Seam Depth. Coal seams between 300 and 1000 meters in depth are preferted to avoid weathered gas zones and to reduce the difficulty and cost of methane development. Ninety-five percent of Chinese coal mines are underground.

- Coal Seam Thickness. Coal seams greater than 2 meters in thickness are preferred to guarantee an adequate and stable quantity of methane.

- Low to Medium Metamorphism and High Rank These characteristics of the coal ensure proper methane generation, adsorption and permeability.

- High Coal Permeability. This characteristic ensures good gas flow.

The coal in many of the regions identified in Figure 3-10 meet most of these criteria; as a result, China has significant coalbed methane reserves. To develop this resource requires a well developed regional industrial base and a large demand for coalbed methane in order to raise capital and create the necessary commercial impetus. 


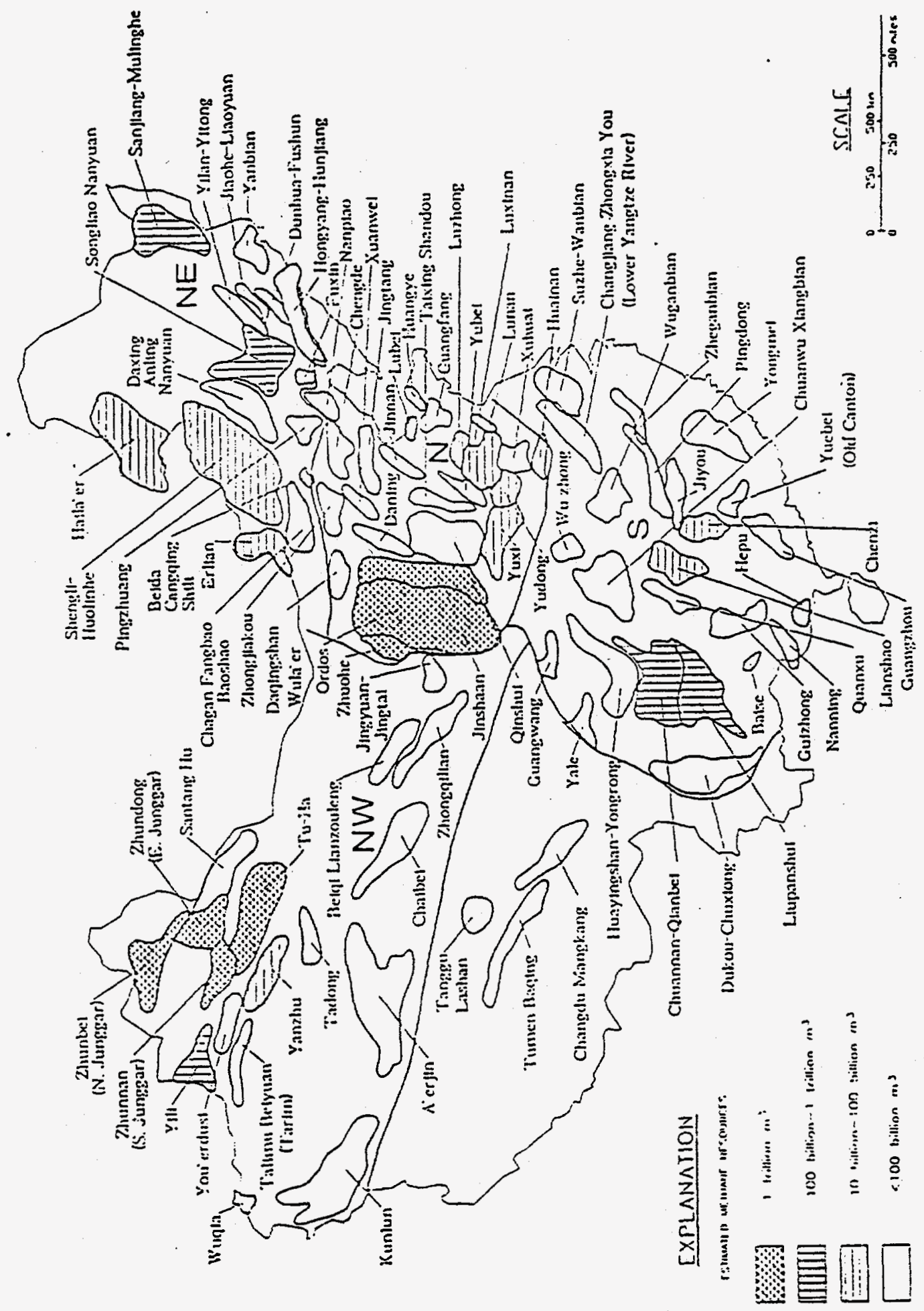

FIGURE 3-10. Location Map of China's Coal Basins and Estimated Methane Resources 
China is the world's number one emitter of coalbed methane, releasing approximately one-third of the world's total. It is estimated that in 1994, methane emissions from high gas coal mines were approximately 155 BCF (USEPA, 1995b); other sources indicate that total coalbed emissions in China in 1989 were 475-830 BCF (Kuchgessner et al, 1995). Over 60\% of the methane emissions came from coal mines in 5 Chinese Provinces - (1) Heilongjiang, (2) Liaoning, (3) Shanxi, (4) Sichuar and (5) Guizhou (USEPA, 1993). Of the amount of methane released, $13 \%$ (20 BCF) was recovered and $9 \%$ (14 BCF) was utilized. Almost 75\% of the methane recovered, and $85 \%$ of that utilized, occurred in the three Provinces - Liaoning, Shanxi, and Sichuan.

Assuming that between $25 \%$ and $35 \%$ of the coalbed methane released from coal mining operations in China is recoverable, it is then possible to recover an additional 115-285 BCF of methane per year over what is recovered today (Coal Industry Advisory Board, 1993). Additional coalbed methane recovery from non-mined coal seams is also likely.

\subsubsection{Potential Uses for Coalbed Methane in China}

The best uses for the coalbed methane recovered from Chinese coal mines will vary depending upon the quality/quantity of the gas and local energy markets. However, general statements can be made about the potential uses for the gas.

One option is to use the methane to substitute for coal to meet the energy needs at the coal mines. Such needs include:

- on-site heating of water and air,

- thermal coal drying;

- heating of ventilation air, and

- production of electricity and heat in coal mine boilers.

Coalbed methane can be used as a substitute for coke gas, coal or natural gas in local residences and businesses. It also can be used with gas turbines or fuel cells to produce on-site electricity and heat. In addition, depending upon the quality of the gas and its proximity to gas pipelines, it could be transported to other regions of China and used for electric power, industrial, commercial or residential applications. However, since there are very few natural gas pipelines in existence in China today, this latter option may be cost prohibitive.

\subsubsection{Barriers To the Recovery of Coalbed Methane in China}

Despite the large coalbed methane resource that exists in China, there are several factors that will impede its recovery. These include:

- The capital cost of coalbed methane projects. The cost of exploration drilling, producing, transporting, and converting end-use equipment to use coalbed methane may be prohibitively expensive.

- The cost of installing coalbed methane upgrading, transportation and utilization systems.

- Lack of clear legal authority (and precedent) regarding the ownership of the methane. 
- Lack of understanding in many coal regions of China regarding the value of coalbed methane. As a result, many coal operations focus only upon coal recovery.

- Lack of sufficiently proven recovery technologies to meet the economic and technical conditions which exist in China.

\subsubsection{Poland}

\subsubsection{Population and Land Use}

Poland, with a population of approximately 39 million is among the 40 most-populated countries in the world. Forty-one percent of the population lives in rural areas. It contains 5 cities with populations in excess of 500,000: Warsaw (1.7 million); Lodz (850,000); Krakow (740,000); Wroclaw $(640,000)$; and Poznan $(575,000)$. The population density of Poland is moderate (i.e., 100 to 250 people per square mile) except in its northern most areas where population density is $50-100$ persons per square mile (World Book, 1988).

Figure 3-11 shows the main regions of Poland. The Coastal Lowlands of Poland, a narrow strip of land along the Baltic coast in the northwest contains three ports - Gdansk, Gdynia and Szczecin. No other major population centers exist in the region.

The Baltic Lakes Region covers most of northern Poland. The region contains thousands of small lakes and is very sparsely populated.

The Central Plains stretch across the entire width of Poland south of the Baltic Lakes Region. This region contains most of Poland's agricultural lands. In addition, it is the region in which three major cities are located: Poznan, Warsaw and Wroclaw.

The Polish Uplands consists of hills, low mountains and plains located south of the Central Plains Region; it is rich in mineral resources. The Katowice area is the most highly industrialized region in Poland. It is here that the coal fields, as well as copper, lead and zinc, are found.

The Carpathian Forelands lie within the branches of the Vistula and San Rivers in southeastem Poland. Much of this region is densely populated. Krakow is the region's most important manufacturing center.

The Western Carpathian Mountains form the southernmost region of Poland. This is a mountainous region which contains rural towns and villages scattered throughout.

The Sudetes Mountains border southwestern Poland. The region is scattered with farms and small cities and towns and is the textile center of Poland.

\subsubsection{Energy Resources}

Coal dominates Poland's fuel mix, comprising $76 \%$ of the energy consumed in 1992 . Poland's energy demand in 1991 was approximately 2.5 quadrillion $\left(10^{15}\right)$ Btu. Approximately $45 \%$ of the energy used in Poland is consumed in the household and commercial sectors; $40 \%$ was consumed in the industrial sector. The remaining $15 \%$ was consumed in the transportation sector. Approximately $96 \%$ of the electricity generated from all Polish sources (PSE and all hard coal generating and CHP companies under the Ministry of Industry and Trade, and the Ministry of Privatization) in 1991 was derived from coal. 


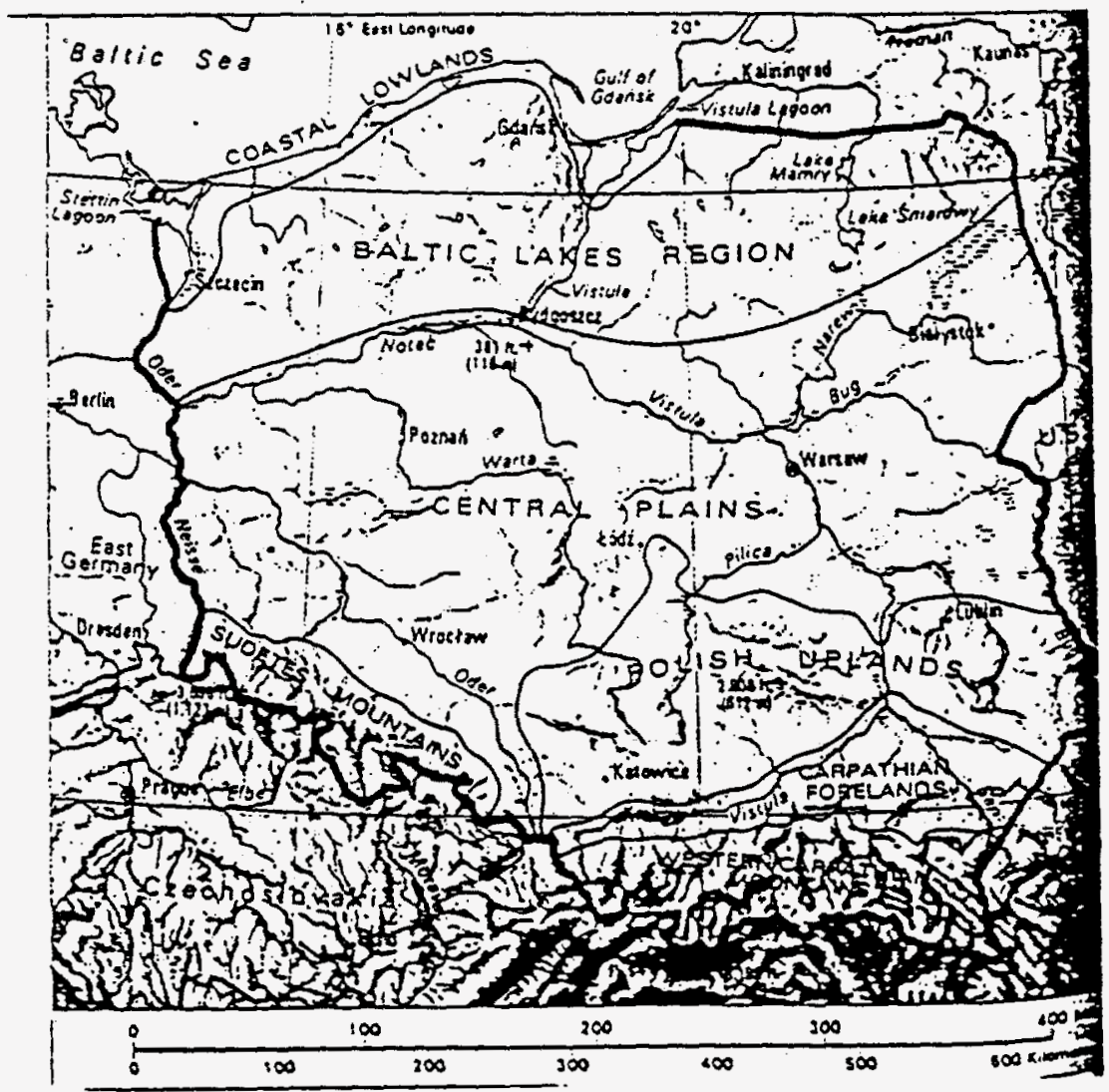

FIGURE 3-11. Regions of Poland 
In 1991, approximately $44 \%$ of the energy consumed in the household and commercial sectors was derived directly from coal or coke. Indirect use of coal via electricity and steam accounted for $39 \%$ of this sector's energy demand. Natural gas (12\%) and oil (5\%) made up the rest of the energy demand in this sector. It is expected that the current trend toward more use of natural gas and electricity in this sector is expected to continue.

Direct use of coal and coke accounted for $36 \%$ of the energy demand in Poland's industrial sector in 1991. In addition, coal-based electric power provided $50 \%$ of the energy consumed in this sector. Natural gas (10\%) and oil (4\%) made up the remainder of the industrial energy demand in 1991. A program was initiated to switch industrial consumers of coke oven gas to natural gas.

Eight-six percent of the transportation sector used oil in 1991 to meet its energy demand. The remaining demand in this sector was met by coal and coke in the form of electricity and steam ( $9 \%)$ and direct use of coal and coke (5\%).

Polish hard coal production in 1993 was approximately 130 million tons. Hard coal is produced from three Basins in Poland - the Upper Silesian Coal Basin (USCB), the Lower Silesian Coal Basin and the Lublin Coal Basin. The locations of these and other energy producing regions in Poland are shown in Figure 3-12 (USEPA, 1995c). The USCB produced 127 million tons or $98 \%$ of Poland's coal in 1993. Polish coal consumption in 1993 was approximately 105 million tons. The remainder of the hard coal produced (25 million tons) was exported. Lignite (brown coal) production in Poland in 1993 totalled 68 million tons; all of it was consumed domestically.

Natural gas production in Poland in 1993 was approximately 5 billion cubic meters while its consumption was almost 11 billion cubic meters. Russia supplies most of the imported natural gas. While natural gas consumption is projected to increase dramatically by the year 2010 - to as much as 43 billion cubic meters (by World Bank estimates) - the decline in domestic production and coupled with uncertainties in expanded supply from Russia, have introduced considerable uncertainty regarding the ability of Poland to meet this projection.

\subsubsection{Coalbed Methane Recovery Potential}

It is estimated that Poland's coalbed methane resources range from 14-46 TCF. In 1993, coalbed methane emissions in Poland were estimated to be 30 to $75 \mathrm{BCF}$. Of that amount, $9.5 \mathrm{BCF}$ were recovered and 2 BCF were utilized. Table $3-3$ provides information on coal production, and coalbed methane resources in the three principal polish coal basins. 


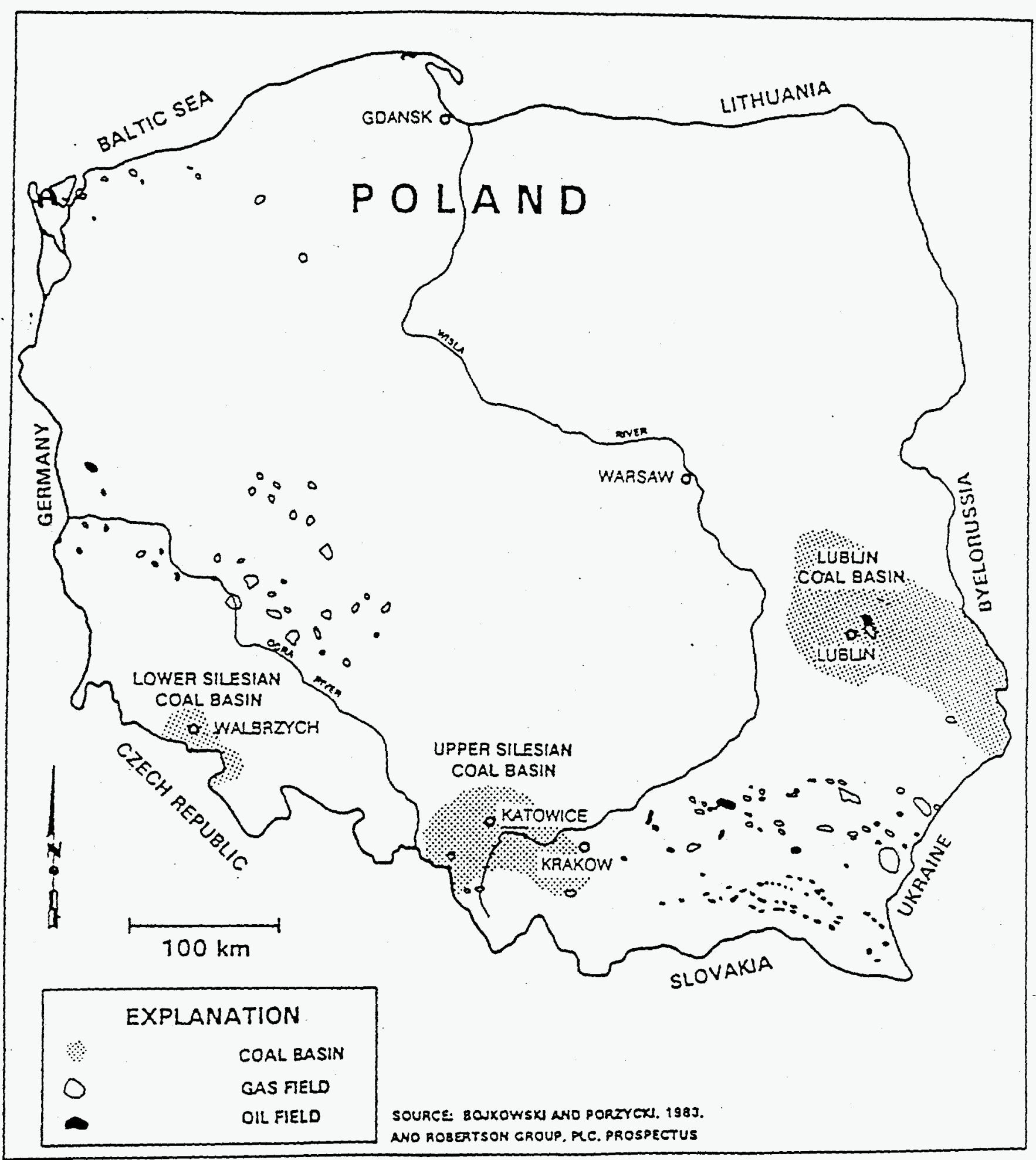

FIGURE 3-12. Location of Coal Basins, Oil Fields, and Gas Fields, Poland 
Table 3-3

Coal and Coalbed Methane in 3 Polish Basins

\begin{tabular}{|l|c|c|c|}
\hline Basin & Upper Silesian & Lower Silesian & Lublin \\
\hline $\begin{array}{l}\text { Coal Resources } \\
\text { (billion tons) }\end{array}$ & 56.9 & 0.2 & 7.6 \\
\hline $\begin{array}{l}\text { Hard Coal Production } \\
\text { (billion tons) }\end{array}$ & 127.2 & 1.2 & 2.2 \\
\hline $\begin{array}{l}\text { Methane Potential } \\
\text { (TCF) }\end{array}$ & 14 & Unknown & Unknown \\
\hline $\begin{array}{l}\text { Methane Liberated } \\
\text { (BCF) }\end{array}$ & 26 & 1 & 0 \\
\hline $\begin{array}{l}\text { Methane Utilized } \\
\text { (BCF) }\end{array}$ & 6 & 0 & 0 \\
\hline
\end{tabular}

Assuming 25\%-35\% recovery of coalbed methane emissions, 5 to 23 BCF per year of additional recovery is possible (Coal Industry Advisory Board, 1993). Considerable recovery from unmined coal seams is also possible.

\subsubsection{Potential Markets for Coalbed Methane in Poland}

Many markets exist for coalbed methane in Poland. This is brought about by Poland's increasing demand for, and declining production of, natural gas.

In the Upper Silesian region, coalbed methane has a large potential market for direct industrial use. This region is the most heavily industrialized in Poland and the largest energy consuming region as well. As a result, coalbed methane has potential to be used in the machinery, iron and steel, food, chemicals, and coal industries displacing coal and coke oven gas. The potential also exists for the methane to be used by industries who self-generate their electricity, displacing coal currently used for this application.

Currently 280,000 domestic consumers utilize coke oven gas for heating and cooking. As the coking operations in Poland are shut down, residences are being converted to natural gas. Since most of the gassy mines in Poland are in towns that currently use coke oven gas and that possess a gas network, this is a ready-made market for coalbed methane.

Piping coalbed methane in Poland does not appear to be a viable option today. This is so because: (1) natural gas pipelines are operating at full capacity; and (2) the quality of the methane in Poland (30 to $50 \%$ methane concentration) is not suitable for pipelines.

\subsubsection{Barriers to the Recovery of Coalbed Methane in Poland}

Despite the large coalbed methane resource that exists in Poland, there are several factors that will impede its recovery. These include: 
- The capital cost of coalbed methane projects. The cost of exploration, drilling, producing, transporting, and converting end-use equipment to use coalbed methane may be prohibitively expensive.

- Lack of clear legal authority (and precedent) regarding ownership of the methane.

\subsubsection{India}

\subsubsection{Population and Land Use}

The population of India in 1993 was 891 million, making it the second most populated country in the world behind China. Although India is a very large country, it has a fairly high population density estimated to be 275 people per square mile. Approximately $27 \%$ of the population lives in urban areas.

There are several very large population centers in India. These include:

\begin{tabular}{lc} 
City & Population (millions) \\
\cline { 2 - 2 } Bombay & 12.6 \\
Calcutta & 11.7 \\
New Delhi & 8.5 \\
Madras & 5.7 \\
Bangalore & 4.6 \\
Hyderabad & 3.5 \\
Ahmedabad & 3.6
\end{tabular}

India also has many small farm villages. It is estimated that there are 557,000 such villages with populations less than 1,000 .

There are three major topographical areas of India (Figure 3-13).

- The Himalaya Mountains extend along much of the north border of India. This region is. sparsely populated.

- The Gangetic Plain consists of the entire northern part of India, less the Himalaya Mountains. This is a well watered and very fertile region that is densely populated.

- The Deccan Plateau consists of the peninsula of India. It too is densely populated.

\subsubsection{Energy Resources}

India's total energy production in 1992 was estimated to be 170 million tons of oil equivalent (mtoe) (US DOE, 1994b). Its 1992 consumption was estimated to be $210 \mathrm{mtoe}$. In 1987, India's energy was consumed in the following proportions:

$\begin{array}{cc}\text { Sector } & \text { Share (\%) } \\ \text { Industrial } & 51.4 \\ \text { Transportation } & 23.0 \\ \text { Residential } & 11.2 \\ \text { Agricultural } & 3.5 \\ \text { Other } & 10.9\end{array}$




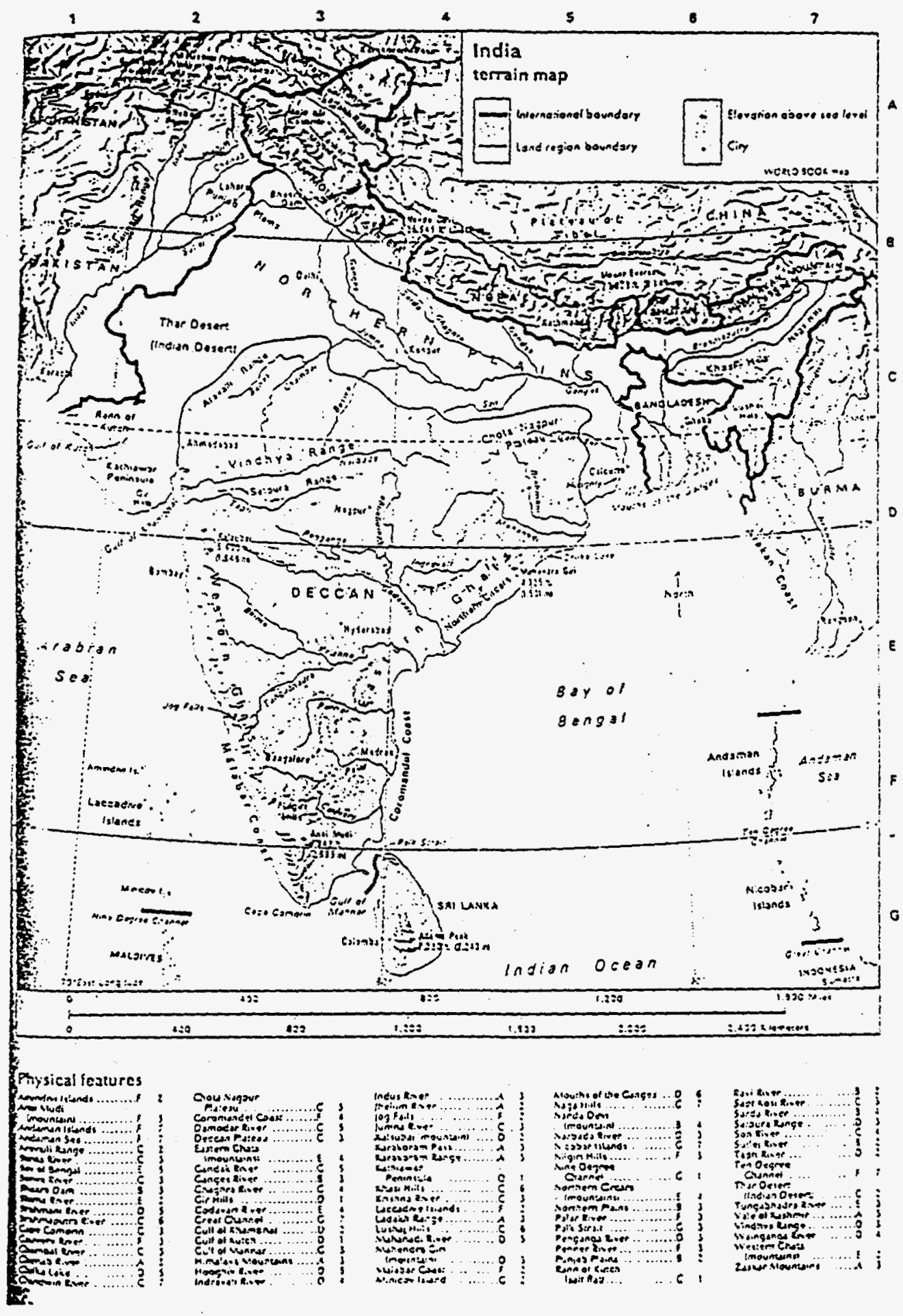

FIGURE 3-13. Topography of India 
India uses the complete range of energy options. In 1992:

- $62.1 \%$ of the energy consumed was coal-based, of which $57 \%$ was used for electric power production;

- $27.2 \%$ was based on oil;

- $7.6 \%$ was based on natural gas;

- $2.8 \%$ was based on hydroelectricity; and

- $0.3 \%$ was based on nuclear power.

Coal is the dominant fuel used in India; it is the world's third largest producer of hard coal. In 1994, Indian coal reserves were estimated to be between 69 and 194 billion tons (USDOE, 1994). India's coal production in 1994 was approximately 303 million tons; its consumption was 310 million tons. Although in 1991, approximately $60 \%$ of the coal produced in India was surface mined, two-thirds of the 530 operating coal mines were underground. Coal is generally located in the poorer regions of India (i.e., Bihar, Uttar Pradesh, Madhya Pradesh, Orisa, and West Bengal, although some is located in wealthy regions like Maharashtra). Figure 3-14 shows the locations of the major coal fields in India.

In 1992/93, India produced approximately 19.6 billion cubic meters of natural gas (American Embassy, 1993). Seventy-five percent of the gas produced in India was consumed for the production of fertilizer and electric power. Because of inffastructure delays in building gas-fired powerplants, fertilizer and petrochemical plants, gas demand has not risen as rapidly as projected.

Significant quantities of natural gas are flared, again because of delays in building the infrastructure needed to capture and transport the gas. In addition, LPG imports increased $77 \%$ from $1991 / 92$ to $1992 / 93$ to 380,000 metric tons. LPG has become very popular for residential heating and cooking. A backlog of 7 million residences are awaiting LPG hook-ups.

In 1994, electrical generating capacity in India was approximately $82 \mathrm{GW}$ (including autoproducers and private power). Sixty-nine percent of the electricity was produced by coal. India has electrified $80 \%$ of the country. However, only $55 \%$ of the population currently has access to electricity.

\subsubsection{Coalbed Methane Recovery Potential}

India's coalbed methane resources are estimated to be nearly $50 \mathrm{TCF}$. Although India has considerable coal resources, its coal is less gassy than other coal producing countries (India University of Environment and Forests, 1992). In part this is because much of the coal is shallow and surface mined. Coal seams in Orisse, Uttar Pradesh, Madhya Pradesh, Andhra Pradesh and Maharashtra are especially of low gas value.

Approximately $20 \mathrm{BCF}$ of coalbed methane is emitted from coal mines each year in India. Although surface mines produce nearly twice as much coal as underground mines in India, underground mines produced four times the amount of coalbed methane in 1991. No coalbed methane is currently recovered in India. 


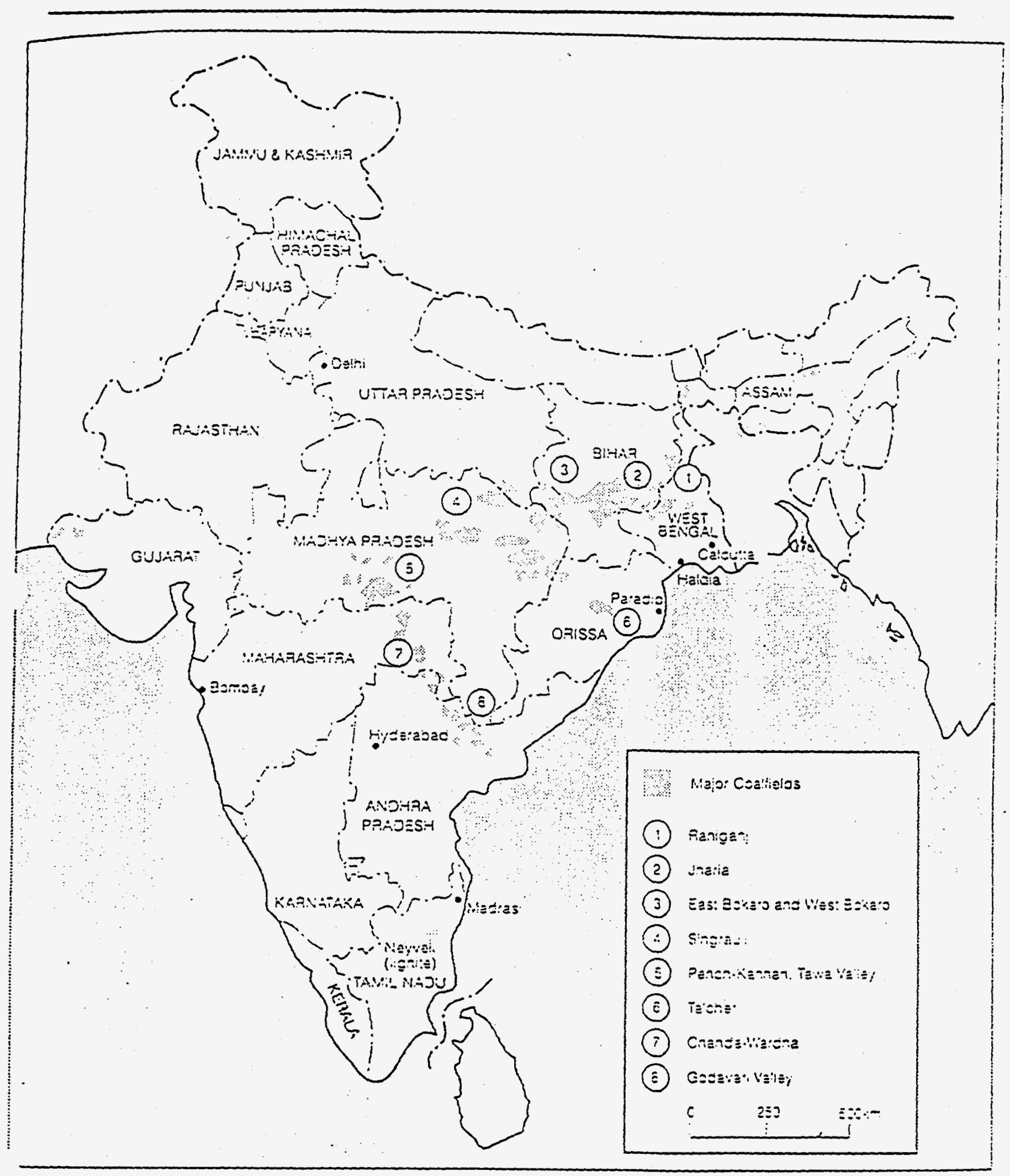

FIGURE 3-14. India: Principal Coal Fields 


\subsubsection{Potential Markets for Coalbed Methane in India}

As a result of its growing appetite for natural gas and LPG, coalbed methane markets in India are potentially large. Some of the market applications include:

- as a source of heat and electricity at the coal mines.

- as a substitute for naphtha in the fertilizer and petrochemical industries. (The Indian government is currently encouraging the use of altemative fuels to displace petroleum-derived fuels).

- as a substitute for fumace oil in powerplants.

- as a substitute for kerosene in the residential market.

- as a substitute for LPG for home heating and cooking.

Several of these market applications could enable coalbed methane to meet the energy needs of remote communities and villages in India. If only 35 to $45 \%$ of the methane currently liberated from coal mines were recovered and used, 7 to $9 \mathrm{BCF}$ of gas would be available for the marketplace.

\subsubsection{Barriers To the Recovery of Coalbed Methane in India}

Despite the large coalbed methane resource that exists in India, there are several factors that will impede its recovery. These include:

- the capital cost of coalbed methane projects. The cost of exploration, drilling, producing, transporting, and converting end-use equipment to use coalbed methane may be prohibitively expensive.

- lack of clear legal authority (and precedent) regarding ownership of the methane.

- high tariffs for imported goods and materials.

- an excessive bureaucracy in India that delays new concepts, like the recovery of coalbed methane.

- concerns over loss of intellectual property rights. 


\subsection{GLOBAL PROSPECTS FOR SMALLSCALE, FLUIDIZED-BED AND COAL FIRED DIESEL POWER SYSTEMS IN DEVELOPING COUNTRIES}

As indicated in Section 2, the market indicators for fluidized-bed and coal-fired diesel power systems in remote applications worldwide include: low population density, low electricity use per capita, proximity to coal (and coal infrastructure), percent diesel generators, and access to water. This section identifies and discusses these indicators (except for access to water) for 42 developing countries.

The World Bank classifies 110 countries as "developing" with respect to their power sector.' Only a subset of these countries - those who carrently produce/consume coal - are potential markets for small-scale, fluidized bed and coal-fired diesel units. Table 4-1 indicates data on the key market indicators for those countries that produced/consumed coal in 1990 (and thereby are presumed to have coal infrastructure):

- rural population (percent of total 1990 population)

- electricity/capita ( $\mathrm{kWh}$ per person)

- electricification ratio (percent)

Data for 1990 was used since it was readily available for all the indicators of interest; the electrification ratio was not available for many countries. As evident from reviewing Table 4-1, no correlation exists between the percent rural population, electricity/capita and the electrification ratio.

The following sections $(4.1-4.5)$ organized by region, discuss the electricity supply/demand situation in each of the countries identified in Table 4-1. Within each region the countries are organized by their state of development (GNP/capita rank, lowest to highest). A market assessment discussion is included with each country profile; it provides an indication of the planned (or prospective) electric power developments and resource preferences of the country. Based on this information an assessment of the market potential for small-scale FBC and coal-fired diesels is examined in Section 4.6.

\subsection{Market Assessment: Africa}

\subsubsection{Mozambique}

Mozambique generates up to 2 TWh per year of electricity, but most of it originates from Hidroelectrica de Cahora Bassa's 2,075 MW hydraulic plant located at Cahora Bassa Dam along the upper reaches of the Zambezi River. In the past, most of this power was exported to South Africa. The other Mozambique utility, Electricidad de Mozambique (EDM) has an interconnected system with three hydro plants, a steam-electric plant in the capital (Maputo), two gas turbine plants, and seven diesel plants. There are also four additional remote (non-interconnected) diesel sites.

1 Developing countries were defined as either low income economies or lower middle income/middle income economies (less than \$2,500 per capita in 1990).

2 The discussion of the supply/demand situation draws extensively on Utility Data Institute, 1996, International Directory of Electric Utilities, Eighth Edition (January). 


\begin{tabular}{|c|c|c|c|c|c|c|}
\hline \multicolumn{7}{|c|}{ TABLE 4.1 } \\
\hline \multicolumn{7}{|c|}{$\begin{array}{l}\text { Indicators of Electricliy Access and Remoteness } \\
\text { for Selected Developing Countrles }\end{array}$} \\
\hline Rank" & Country & $\begin{array}{l}\text { GNPICapita } \\
\text { (1990 US\$) }\end{array}$ & \begin{tabular}{|c|} 
Rural Pop \\
$(\% 1990$ TOTAL $)$
\end{tabular} & $\begin{array}{c}\text { Electrlcity/Caplta } \\
\text { (kWh) }\end{array}$ & E.Ratlo (\%) & $\begin{array}{c}\text { Electrleity imports, } \\
1990(\%)^{\circ}\end{array}$ \\
\hline 1 & Mazambique & 80 & $\underline{3}$ & 52 & -0 & 40.1 \\
\hline 2 & Tanzania & 110 & 67 & 36 & 2 & $=$ \\
\hline 5 & Nepal & 180 & $\infty$ & 41 & 9 & 4.2 \\
\hline 8 & Laos & 200 & 81 & 88 & 12 & 1139.7 \\
\hline 9 & Malawi & 200 & 88 & 6 & -6 & - \\
\hline 10 & Bangladesh & 210 & 84 & 74 & 14 & $=$ \\
\hline 11 & Burundi & 210 & 96 & 22 & $<5$ & 109 \\
\hline 12 & Zaire & 220 & 60 & 162 & $=$ & 19.81 \\
\hline 14 & Madagascar & 230 & 75 & 48 & $=$ & $=$ \\
\hline 17 & Nigeria & 340 & 65 & 102 & $=$ & {$[1.0]$} \\
\hline 18 & Niger & 310 & 80 & 46 & ${ }^{\circ}$ & 534 \\
\hline 21 & India & 360 & 73 & 338 & 55 & 0.3 \\
\hline 23 & China & 370 & 44 & 550 & 66 & 0.3 \\
\hline 25 & Kenya & 370 & 64 & 133 & -6 & 5.3 \\
\hline 26 & Pakistan & 390 & 68 & 391 & 37 & $=$ \\
\hline 27 & Ghana & 390 & 67 & 336 & 20 & {$[5.7$} \\
\hline 30 & Zambia & 460 & 50 & 781 & $=$ & 23.5 \\
\hline 32 & Sri Lanka & 470 & 79 & 185 & 29 & $=$ \\
\hline 33 & Mauritania & 500 & 53 & 71 & -6 & - \\
\hline 35 & Indonesia & 560 & 69 & 248 & 32 & $=$ \\
\hline 37 & Egypt & 610 & 53 & 754 & $=$ & $=$ \\
\hline 41 & Myanmar & 434 & 75 & 62 & 6 & $=$ \\
\hline 43 & Vielnam & $\mathrm{Na}$ & 78 & 118 & - & - \\
\hline 45 & Zimbabuve & 680 & 72 & 1,064 & $<20$ & 8.4 \\
\hline 47 & Philippines & 730 & 57 & 428 & 61 & 34.6 \\
\hline 50 & Pagua New Guinea & 860 & 84 & 462 & 21 & - \\
\hline 52 & Moroces. & 970 & 52 & 388 & 25 & 1.1 \\
\hline 53 & Cameroon & 950 & 59 & 235 & $=$ & - \\
\hline 59 & Pers & 1.100 & 30 & 642 & $=$ & $=$ \\
\hline 61 & Columbia & 1.260 & 30 & 1.122 & $=$ & 0.6 \\
\hline 62 & Thailand & 1.410 & 67 & 831 & 70 & 1.3 \\
\hline$\sqrt{3}$ & Tunisia & 1.440 & 46 & 682 & 60 & 0.5 \\
\hline 65 & Turkey & 1,640 & 39 & 1.013 & $=$ & {$[1.31$} \\
\hline 66 & Romania & 1.670 & 47 & 3,180 & $\square^{\circ}$ & 12.8 \\
\hline 67 & Poland & 1,680 & 38 & 3,549 & $=$ & 10.81 \\
\hline 68 & Panama & 1,900 & 47 & 1.193 & 58 & 4.0 \\
\hline 70 & Chile & 1.940 & 14 & 1.395 & $=$ & $=$ \\
\hline 72 & Algeria & 2.350 & 48 & 637 & $\square^{\circ}$ & 10.41 \\
\hline 73 & Bulgaria & 2.320 & 32 & 5.083 & $\square^{\circ}$ & 9.6 \\
\hline 74 & Mauritius & 2,310 & 59 & 716 & $=$ & $=$ \\
\hline 75 & Malaysia & 2.340 & 57 & 1.389 & $=$ & 0.21 \\
\hline 76 & Asgentina & 2.370 & 14 & 1,602 & $Z^{\circ}$ & 1.6 \\
\hline 77 & Iran & 2,500 & 43 & 1.004 & $=0$ & $=$ \\
\hline $\begin{array}{l}\text { - Ranked } \\
\text { - Net imp } \\
\text { gross O } \\
\text { - Not as } \\
\text { - No cor } \\
\text { Sources }\end{array}$ & $\begin{array}{l}\text { in ascending order of } \\
\text { orts (GWh) divided by } \\
\text { onsumption. } \\
\text { eessed due to current } \\
\text { nputed in } \alpha \text { computat } \\
\text { Word Bank. 1992. } \\
\text { and G.Wu. } 1994 \text {. Po }\end{array}$ & $\begin{array}{l}\text { P per capita. } \\
\text { ss Consumptio } \\
\text { Government re } \\
\text { om referenced } \\
\text { o Dovolopment } \\
\text { Soctor Statisti }\end{array}$ & $\begin{array}{l}\text { GWh); (I represent } \\
\text { iction on investmen } \\
\text { urees. } \\
\text { port 1992, Dovelor } \\
\text { or Developing Cou }\end{array}$ & $\begin{array}{l}\text { net exports as a pe } \\
\text { in Iran. } \\
\text { ment and the Envir } \\
\text { itries. } 1987.1991 \text {. T }\end{array}$ & int of & inber). \\
\hline
\end{tabular}


Morket Assessment: While Mozambique has one steam-electric plant, it relies extensively on hydroelectricity for baseload power generation. Repairs to the Cahora Bassa facility, resulting from disrepair during their long-running civil war, are underway. Construction of a new $60 \mathrm{MW}$ power plant at the existing Massingir Dam, and several other hydro projects are envisioned. Information on the seven interconnected and four remote diesel plants is not available to assess their conversion to coal-fired systems.

\subsubsection{Tanzania}

Like many other African nations, Tanzania relies largely on hydroelectric power for its electricity. The Tanzania Electric Supply Co. (Tanesco) on the mainland, and the Zanzibar State Fuel \& Power Corp. (ZSFP) on the island of Zanzibar are responsible for all public power generation and delivery. The system now has an installed capacity of $410 \mathrm{MW}$. Wood and biomass fuels provide $91 \%$ of the energy consumed in Tanzania, while imported oil accounts for $7 \%$, with coal and electricity each accounting for only $1 \%$ of primary energy. Since $40 \%$ of the Tanzania's foreign exchange expenditures are for oil, the government is interested in increasing electricity supplies in the near-term. To meet this goal, and the $13 \%$ per annum growth in demand, Tanzania hopes to utilize its largely untapped $6,000 \mathrm{MW}$ of hydro potential. Current expansion plans call for four new hydro plants totalling $632 \mathrm{MW}$. A 6-MW coal-fired power plant is now in operation.

Morket Assessment: Recently, Tanzania has been saddled with a scarcity of hard currency for fuel purchases, which has impacted the operation of its diesel power plants. The result has been electricity rationing and interruptions in Dar es Salaam, the most important export port in East Africa. While Tanzania is exploring increased interconnections with its neighboring countries (Uranda, Kenya, Malawi, Burundi, and Zambia), it is also investigating the development of - and increased reliance on - other indigenous energy-producing resources including: bagasse (already used as fuel for steam plants), biogas feedstock from animal ruminants, photovoltaics, wind and geothermal. Natural gas is also likely to be a major power generation fuel, with the discovery of 1.1 TCF on Songo Songo Island. A $60-$ to 100-MW gas turbine or combined cycle power plant on the outskirts of Dar Es Salaam has been proposed to the World Bank.

\subsubsection{Malawi}

Malawi is a republic in southeastem Africa, which is nearly one-quarter covered by water (Lake Malawi and three other lakes). All baseload electricity comes from four hydroelectric plants (190 MW) operated by the Electricity Supply Commission of Malawi (Escom). Its single gas turbine and six diesel units are used for standby service only. Self-generators are estimated to have $24 \mathrm{MW}$ of capacity from bagasse-fired steam units, diesels, and two small hydro stations.

Morket Assessment. It is expected that Malawi will take advantage of its $400 \mathrm{MW}$ of untapped hydroelectric potential, before it relies on its undeveloped bituminous coal reserves.

\subsubsection{Burundi}

Burundi is one of the most densely populated countries in Africa. However, less than $5 \%$ of its population has access to electricity. The state-owned utility Regie de Production et de Distribution d'Eau et d'Electricite (Regideso) has a capacity of $55 \mathrm{MW}$ and produced $105 \mathrm{GWh}$ in 1991. Regideso purchases the bulk of its electricity from Zaire. Burundi, along with neighboring Zaire and Rwanda, 
has formed an organization - Communaute Economique des Pays des Grands Lacs (CEPGL) - to consolidate power development projects.

Market Assessment. Burandi is likely to rely on the joint power production of CEPGL, and therefore be largely hydro-power based for the foreseeable future.

\subsubsection{Zaire}

Zaire has a considerable abundance of natural resources, including the Congo River, which provides a vast network of navigable waterways and a huge hydroelectric potential. It has been estimated that Zaire has about one-eighth of the world's total hydroelectric potential (120,000 MW). Societe Nationale d'Electricite (SNEL) is the national utility in Zaire; it had a total capacity of 2,504 MW in 1992, most of which was from hydro plants (98\%). In addition to this public capacity, there are also 12 privately-owned hydro plants with a total capacity of $80 \mathrm{MW}$. The largest SNEL stations are INGA I and II, on the Zaire River. INGA II, completed in 1982, has eight $178 \mathrm{MW}$ turbine/generator sets capable of producing more power than needed by Zaire. SNEL has the capability of producing about $11 \mathrm{TWh}$ from its facilities, but usually generates only about one-half this total $(5.5 \mathrm{TWh})$. Internally Zaire is interconnected via four subsystems, but with the exception of the Westem and Southern systems are not connected to each other. Most of the distribution system (62\%) is in the lower Zaire and Kinshasa area.

Market Assessment. While Zaire has 600 -million tons of proven bituminous-coal reserves, along with vast quantities of recoverable oil, natural bitumen and natural gas, its hydroelectric resource base is extensive and continues to be the near-exclusive source of electrical supply. Fiscal restraints have limited SNEL's expansion plans, so most investment projects are devoted to rehabilitation of the existing system, including the effects of accelerated turbine deterioration due to underutilization. Complicating investment in generating capital stock is the unstable political situation which has caused the economy to grow by only $1 \%$ per year since 1960 (independence from Belgium).

\subsubsection{Madagascar}

The island of Madagascar is located off the East Coast of Africa. Electricity service is provided by Jir sy Rano Malagasy (Jirama), the Madagascar Electricity \& Water Corporation. Jirama has a total capacity of $208 \mathrm{MW}$ from 10 hydroelectric plants (108 MW) and 56 diesel plants; with this capacity Jirama generated $450 \mathrm{GWh}$ in 1991 . To decrease dependence on oil, Jirama is expanding its hydroelectric capacity: capacity at Andekaleka which currently supplies one-half of the hydro capacity, is scheduled to double to $116 \mathrm{MW}$, and a feasibility study for a $300 \mathrm{MW}$ plant on the Onive River has been completed. In addition, five new hydro facilities totaling $375 \mathrm{MW}$ are under consideration.

Morket Assessment. Other than the planned hydroelectric expansions, most future power investment in Madagascar is scheduled to be devoted to strengthening the T\&D interconnections between the hydroelectric plants and the coastal demand centers in order to replace current diesel power. 


\subsubsection{Nigeria}

Nigeria is the most populous country in Africa, and at one time possessed one of the most advanced power systems among the developing nations of Africa. At present, the system is plagued by power failures. The Nigeria Electric Power Authority (NEPA) operates 6,611 MW of capacity, it produced 11.3 TWh in 1991, of which $35 \%$ was hydroelectric. The following table delineates the plants operated by NEPA:

\begin{tabular}{llll} 
Plant Name & Size (MW) & Type & Fuel \\
\hline AFAM & 623 & GT & gasioil \\
EGBDN & 972 & GT & gas \\
JEBBA & 642 & hydro & \\
KAINJI & 1056 & hydro & \\
LAGOS & 1350 & F/GT & oil/gas \\
SAPELE & 720 & F & oil \\
SAPELE & 285 & GT & oil \\
SHIRORO & 600 & hydro & \\
UGHELLI & 354 & GT & oilgas
\end{tabular}

F/GT $=$ fossil steam and gas turbine

${ }^{b} \mathrm{~F}=$ fossil steam electric

Besides the power generated by NEPA, independent power generators (i.e., state-owned oil company and other self-generators) produced another $50 \mathrm{GWh}$.

Morket Assessment. A 330-kv transmission line was recently completed linking Nigeria's major urban centers. If and when Nigeria needs more electricity, it can (will) simply stop flaring $70 \%$ of its gas production, and begin burning it in gas engines or gas turbines. Natural gas use is also being advocated by the government in industrial and household applications. With natural gas reserves in excess of 2.8 tcm, Nigeria also signed a joint-venture agreement to liquify and export LNG. To counter a potential shortfall in future natural gas availability for electricity production, Nigeria is rehabilitating its coal mines to resume production that peaked in 1959 and is nonexistent at present.

\subsubsection{Niger}

Most of the land area in Niger is uninhabitable. Over $50 \%$ of the area lies within the Sahara. The central portion of the country is the Sahel, a semiarid and lightly wooded region. The southem and southwestern regions are fertile and forested areas where most of the 8.4 million people reside. Electricity in Niger is produced and supplied by the Societe Nigerienee d'Electricite (Nigelec), which purchases the bulk of its power from Nigeria. In 1991, Nigelec's capacity was $105 \mathrm{MW} ; 36 \mathrm{MW}$ of it is from the Niamey II diesel- and gas-fired station. Niamey II supplied cities in the Niger Valley; 54 diesel units supply the isolated areas. Nigelec produced $230 \mathrm{GWh}$ in 1991 , while it imported $200 \mathrm{GWh}$ from Nigeria.

Market Assessment. Niger is without indigenous energy resources, more than one-half of its electricity is imported and most of the power generated intemally is diesel-fired. Replacement of the diesel units and imported power is possible, but not without importation of fossil fuels from Nigeria. 


\subsubsection{Kenya}

The government-owned Kenya Power \& Lighting Co. Ltd. (KPLC) and its two associated companies, Kenya Power Co. Ltd. (KPC) and Tana River Development Co. Ltd. (TRDC), supply almost all of Kenya's electricity. KPLC owns all the thermal plants and a few hydroelectric stations; TRDC owns hydroelectric plants; and KPC owns some small hydro plants and the geothermal power station. KPC is also importing power from the Urganda Electricity Board (UEB) and is developing future geothermal and hydro resources. Self-generators produce approximately $5 \%$ of Kenya's electricity.

Approximately $70 \%$ of Kenya's electricity is hydroelectric. In 1993, the Kenya power system's interconnected network had an installed capacity of roughly $800 \mathrm{MW}$, with $75 \%$ (600 MW) consisting of hydro. An additional $136 \mathrm{MW}$ were fossil-fired units, and $45 \mathrm{MW}$ were geothermal. Isolated diesel plants accounted for $4 \mathrm{MW}$, with another $30 \mathrm{MW}$ available for import from UEB.

Morket Assessment. Over the last five years, electricity demand has grown by $4.8 \%$ per year. However, if the proposed infrastructure investments are made, this level of growth could be met. The planned capacity additions include: diesel units at Kipeva near Mombasa (75 MW), the Olkaria Northeast geothermal plant ( $64 \mathrm{MW}$ ), and the Sondu/Miriu hydro project (60 MW). All three projects are awaiting further funding - the diesel and hydro plants from Japan. Funding will be difficult unless the electricity tariff structure is altered. Kenya, with World Bank funding is making a determined effor in this regard; at present, electricity tariffs represent only $30 \%$ of the replacement cost of electricity supply.

\subsubsection{Ghana}

Hydroelectricity provides $98 \%$ of all power generated in Ghana. Between 1986 and 1992, domestic electricity demand in Ghana grew at an average annual rate of $9.7 \%$ per year, with total load growing at $7.4 \%$ per year, reflecting a steady expansion of electrification and generating capacity. Total load growth through 2000 is expected to be $2.2 . \%$ per year.

The Volta River Authority (VRA) was formed in 1961 to supervise the construction and operation of the $912 \mathrm{MW}$ plant at Akosombo dam where four $147 \mathrm{MW}$ units were commissioned in 1965, with two $162 \mathrm{MW}$ units added in 1972. In 1981, the $160 \mathrm{MW}$ Kpong plant was finished; in 1992, a $30 \mathrm{MW}$ diesel plant at Tema was added. Both hydro plants are located in the southern portion of the Volta River basin.

VRA distributes power to mining companies, including the Volta Aluminum Co. (Vaico) - its largest customer - and to the Electricity Corporation of Ghana (ECG). Through 1987, ECG was filly responsible for power distribution to all domestic customers, except the mines, several townships and a textile plant. Since 1987, ECG distribution is restricted to the developed southern half of the nation, for which it purchases power from VRA and operates its own $100 \mathrm{MW}$ diesel plant. VRA now distributes power to the northern half of the country through its Northern Electricity Department (NED).

Market Assessment. Following several years of drought resulting in load reductions and legal disputes, VRA has instituted plans to construct a $300 \mathrm{MW}$ combined-cycle power plant at Aboadze near Takoradi. The first $200 \mathrm{MW}$ block of the $\$ 427$ million plant is expected to be in service in 1997 . Beyond Aboadze, VRA is exploring construction of a 400 MW hydro plant at BUI, a 93 MW plant at Hemang on the Pra River, a $50 \mathrm{MW}$ plant at AWISAM also on the Pra, and a $130 \mathrm{MW}$ gas turbine 
plant, which might be built jointly with the Ghana National Petroleum Corp to use gas reserves at the offshore Tano oil fields. To consume this power, VRA and ECG are cooperating on the National Electrification Project which, by 2020 , intends to extend electicity to all towns and villages.

\subsubsection{Zambia}

Wood fuels contribute approximately $75 \%$ of Zambia's primary energy requirements with hydroelectricity the most important source at $15 \%$. Seven hydro facilities - totaling 2,254 MW - have made the Zambia Electricity Supply Corporation (Zesco) a net exporter of power. Zambia's mining company also operates two hydro plants, totaling $48 \mathrm{MW}$, as well as some gas turbine and thermal capacity. In 1992, electricity production in Zambia was 7,780 GWh.

Zesco's three hydroelectric plants - Kafue Gorge (900 MW), Kariba North Bank (600 MW), and Victoria Falls (108 MW) - form an interconnected grid along the southern edge of the country, bordering Zimbabwe. Zesco's smaller plants - Lusiwasi (12 MW), Chishimba (6 MW), Musonda (5 $\mathrm{MW}$ ), and Lunzua (750 MW) - are not linked to the main grid. Neither are its diesels, which have a capacity of $13 \mathrm{MW}$, operating in Kabompo, Kaoma, Kasempa, Luangwa, Lukulu, Mwinilunga, and Zambezi.

Transmission and distribution facilities, while well-established in Zambia, are in debilitated condition (largely attributed to a lack of maintenance and skilled labor) and require policy reform and institutional redevelopment. Currently, the northern and eastern regions of Zambia are linked to the national grid; several ongoing and proposed projects will reinforce reliability and permit export to Malawi. Export to Botswana will be possible when a new $66-\mathrm{kV}$ line is completed. With its newly awarded independence, Zesco is also exploring the possibility of exporting power to Namibia.

Market Assessment. Hydroelectric will likely continue to be the primary source of electricity generation in Zambia for the foreseeable future. In addition to current capacity (identified above), Zesco is considering seven other hydro schemes. The site being most actively considered is at Botoka Gorge on the Zambezi, which could serve both Zambia and Zimbabwe. The current scheme, to be operated in conjunction with Kariba Dam, is designed to provide annual generation of $6.1 \mathrm{GWh}$ from a capacity of 1,600 MW. Consideration of other fuels for electricity generation is unknown; however, Zambia's only coal mine - Maamba Collieries - was recently saved from foreclosure by a South African bank.

\subsubsection{Mauritania}

Mauritania is an Islamic Republic in northwestem Africa situated almost entirely within the Sahara Desert. Societe Nationale d'Eau et d'Electricite (Sonelec) supplies electric power to the urban centers of Nouakchott and Nouadhibou as well as some isolated areas in Mauritania. In 1991, Sonelec had an installed capacity of $105 \mathrm{MW}-61 \mathrm{MW}$ hydro and $44 \mathrm{MW}$ diesel - and produced $135 \mathrm{GWh}$. Interconnection with Mauritania autoproducers (i.e., industrial self-generators), who have $70 \mathrm{MW}$ of installed capacity, may increase reliability.

Market Assessment. Besides interconnection with Mauritania autoproducers, Sonelec also plans to import power, to meet future electricity needs, from the Manatali hydro plant expected to be constructed in Mali. 


\subsubsection{Egypt}

In Egypt, electrical supply and central electrical planning and dispatching are the responsibility of the Egyptian Electricity Authority (EEA). The EEA owns all the major generating facilities and provides bulk power to municipal and regional distribution authorities and agencies. The Country Electricity Authority is responsible for subtransmission operations and the development of a national ruralelectrification network. Electricity sales have grown rapidly over the last 10 years - up $70 \%$ from 1984 to 1993 . But this growth is expected to slow by the end of the 1990s. During this same period, EEAs installed capacity expanded from 6,123 MW to $11,911 \mathrm{MW}$ (95\% increase), while peak load increased by $61 \%$, from $4,672 \mathrm{MW}$ to $7,503 \mathrm{MW}$.

Approximately 9,196 MW (77\%) of the installed capacity is in thermal plants, which also contribute about $75 \%$ of Egypt's electrical output - $47 \mathrm{TWh}$ in 1992/1993. The remainder is from the large hydroelectric plants at Aswan: the High Dam (2,100 MW), Aswan 1 (345 MW), and Aswan 2 (270MW). The large steam-electric plants operated by EEA are at Abu Qir ( $900 \mathrm{MW}$ ), Abu Sultan (600 MW), Ataka (900 MW), and Shoubrah (1,260 MW). Large gas-turbine plants are at Damietta ( $750 \mathrm{MW}$ simple-cycle GT and $375 \mathrm{MW}$ combined cycle). Cairo South has $440 \mathrm{MW}$ of gas turbine capacity and $255 \mathrm{MW}$ of steam-electric capacity.

Market Assessment. The three Aswan power plants have virtually exhausted the hydroelectric capabilities of the section of the Nile under Egyptian control, leaving thermal plants the primary nearterm option for system expansion. In 1994, Egypt relied on combustion of natural gas (73\%) and heavy fuel oil $(27 \%)$ to fuel its thermal power plants. However, the Ministry of Electricity and Energy reports that by the year 2000 , natural gas will be used in all generating units and oil will be saved for export. By 2010 , Egypt hopes to have a fuel mix of $9.5 \%$ coal, $8.9 \%$ hydro, $75 \%$ natural gas, and $6.6 \%$ nuclear (although long-discussed nuclear projects show little signs of progress). These goals are reflected in EEA's current power plant construction program: development of a \$1 billion gas-fired power plant at El-Kureimat ( $2 \times 600 \mathrm{MW}$ ), with duel-fuel capability; $630 \mathrm{MW}$ extension ( $2 \times 315$ $\mathrm{MW}$ ) at the $350 \mathrm{MW}$ Cairo West plant; efficiency improvements at the oilgas Shoubrah plant ( $4 \times 315$ $\mathrm{MW}$; and combined-cycle conversion of the $150 \mathrm{MW}$ Cairo South plant. A $90 \mathrm{MW}$ hydroelectric plant is also under construction at ESNA. Increased foreign participation in private power plants and power plant privatization are expected if Egypt eliminates the $6 \%$ subsidy on electric rates.

\subsubsection{Zimbabwe}

The Zimbabwe Electricity Supply Authority (ZESA) was formed from the Central African Power Corp., the Electricity Supply Commission, and municipal electricity departments in Baluwayo, Gweru, Harare, and Mutare. ZESA is the sole authority for the generation, transmission and distribution of electricity in the country.

ZESA's installed capacity is $1,930 \mathrm{MW}$, consisting of $663 \mathrm{MW}$ at Kariba South and the remainder at coal-fired plants comprised of Hwange (920 MW), Harare (135 MW), Munyati (120 MW), and Bulawayo (120 MW). Most of the privately-owned generation has been dismantled. The tranmission system interconnecting these plants to the population centers runs north to south. Major transmission lines also connnect Zimbabwe with Zambia; Zimbabwe typically imports $10 \%$ of its power from Zambia. Interconnections are in progress (or planned) to import electricity from Botswana, South Africa and Mozamique. A 5\% Development Levy on all electricity charges has been recommended to defray the cost of these transmission projects, along with needed power plant modernization and refurbishment. 
Morket Assesment. The severe drought in the early-1990s has changed some of the critical assumptions regarding the desirability of additional hydroelectric expansion. As of 1993, ZESA's expansion plan was geared to reaching 2,000 MW of installed capacity (from 1,930 MW), with sales of 13 TWh per year, by 2000 (an annual growth rate of $3.6 \%$ ). New capacity would come from two 220 MW units at Hwange by the end of the century, although Kariba South may be expanded to $750 \mathrm{MW}$. While the desirability of hydro expansion is being questioned, several sites on the Zambesi River are being jointly explored by Zimbabwe and Zambia: Batoka Gorge, Devil Gorge, Mpata Gorge, and Victoria Falls. Plans are furthest advanced for a $800 \mathrm{MW}$ plant at Batoka.

Rural electrification is underway in Zimbabwe, although less than $20 \%$ of all households in the country are connected. The government is particularly eager to connect poor urban sections to the grid, to reduce the strain on wood an other biomass fuel resources.

\subsubsection{Morocco}

The Office National de l'Electricite (ONE) supplies $90 \%$ of the electricity in Morocco; Regies Autonomes de Distribution distributes electricity to 10 of Morocco's largest towns. In 1993, ONE's installed capacity was $2,360 \mathrm{MW}$, consisting of $1,733 \mathrm{MW}$ of steam and gas turbines (73.4\%) and diesel units, and $687 \mathrm{MW}$ of hydro power (29.1\%). In addition to this domestic capacity, 1,027 GWh was imported from Algeria, and $135 \mathrm{GWh}$ supplied by other generators; greater levels were imported during the two-year drought that ended in mid-1993, when a peak power shortfall of $250 \mathrm{MW}$ existed.

The electrification ratio in Morocco is still relatively low at approximately $25 \%$. A recent program conducted by ONE extended service to 2000 additional rural villages, yet much of Morocco's countryside remains without electricity. The European Investment Bank is currently funding a \$73 million power distribution expansion project, which is expected to dramatically affect power availability through much of nal Morocco in the near future.

Market Assessment. To meet the estimated $7 \%$ growth in demand, ONE is exploring many options. On the supply-side, ONE currently plans to have $2,940 \mathrm{MW}$ of additional fossil-fuel generated capacity available by 2000 . The first two units at Jorf Lasfar $(4 \times 300 \mathrm{MW})$ are now in service; the second two units are to be completed by 1999 . A consortium, including CMS Generation has been selected to purchase and operate the plant. Revenues from privatization of Jorf Lasfar are intended to be used to complete other power facilities. In addition to Jorf Lasfar, three sets of $3 \times 34 \mathrm{MW}$ gas turbines have been recently completed, and two hydro plants are under construction at $\mathrm{Al}$-Wahda $(3 \times 80 \mathrm{MW})$ and Allal El Fassi ( $3 \times 83 \mathrm{MW}$ ). A pair of combined-cycle plants are under development at Mohammedia and Kenitra, but it is not yet clear who will build them. ONE has also made an agreement to build a large wind-energy plant at Dakhla.

The Moroccan government plans to spend $\$ 1$ billion in the near-term on the power sector. At the same time, the private sector was invited to become equity partners in the aforementioned projects. Despite these steps, the basic problem with Morocco's energy sector is the necessity for additional import to compensate for the lack of significant domestic fossil fuel reserves; imported oil currently accounts for $80-90 \%$ of the country's commercial energy requirements. One option being explored by Morocco is to obtain royalty gas by providing transit rights for Algerian natural gas shipments to Spain via the Maghreb-Europe pipeline. However, before the Moroccan government can use this gas, a complete gas-distribution infrastructure will have to be constructed. 


\subsubsection{Cameroon}

Societe Nationale d'Elecricite du Cameroon (Sonel) is responsible for the generation, transmission, and distribution of electricity throughout the national territory. It had $755 \mathrm{MW}$ of installed capacity in 1991, most of it being hydroelectric, with diesel providing the remainder. Sonel is $93 \%$ owned by the Republic of Cameroo; the remaining shares are held by the French Central Fund for Economic Cooperation.

In 1991, Sonel generated 2,940 GWh; all but $41 \mathrm{GWh}(1.4 \%)$ came from hydro. The transmission system is divided into four zones: North, an interconnected network supplied by Lagdo hydro station and small diesel plants; Littoral; West, Central, and South, an interconnected network supplied by the Edea and Song-Loulon ( $388 \mathrm{MW}$ ) hydro stations; and the isolated areas. A newly created East zone is supplied at the moment by thermal plants.

Market Assessment. Cameroon has 404-million bartels of proven oil reserves, $113 \mathrm{bcm}$ of natural gas, and considerable untapped hydro potential. At present, almost all generation is hydro-based, with diesel for backup and distributed generation.

\subsubsection{Tunisia}

Tunisia is a relatively small country of 8.6 million inhabitants situated between Algeria and Libya in North Africa. Approximately $40 \%$ of the land area in Tunisia is in the Sahara; some of the land area in south-central Tunisia consists of low-lying salt lakes known as shatts.

Societe Tunisienne de l'Electricite et du Gaz (STEG) was formed in 1962, when Tunisia nationalized its power industry. In 1992, STEG had a total installed capacity of 1,329 MW. Steam and gas-turbine plants dominate the system, with some hydro and isolated diesel. STEG produced $5,479 \mathrm{GWh}$ in 1992; autoproducers generated an additional $702 \mathrm{GWh}$.

Market Assessment. Over the next several years, STEG plans to boost its capacity to 1,500 MW; one element is a $357 \mathrm{MW}$ combined-cycle plant at Sousse that recently came into service. Except for some isolated diesel units, STEG operates an interconnected system. Rural electrification is underway; to date it supplies nearly $60 \%$ of Tunisia.

\subsubsection{Algeria}

Algeria is a large republic at the westem end of North Africa, between Morocco and Libya. More than $90 \%$ of the land area consists of gravel-covered deserts, leaving only about $3 \%$ of Algeria arable. The country has large reserves of oil and natural gas, and is a major exporter of LNG.

Societe Nationale d'Elecricite et du Gaz (Sonelgaz) is responsible for all public power supply. In 1991, Sonelgaz had a total capacity of $4,877 \mathrm{MW}$, with $400 \mathrm{MW}$ of captive generating capacity. In addition to providing electricity internally, Sonelgaz also exports power to the neighboring countries of Tunisia and Morocco.

Market Assessment. Since its coal reserves and hydro potential are limited, Algeria plans to take advantage of its proven oil and gas reserves -9.2 billion barrels and $3.25 \mathrm{tcm}$, respectively. Sonelgaz hopes to increase its capacity to $9,000 \mathrm{MW}$ by 1999 , primarily through the addition of $4,000 \mathrm{MW}$ of new gas-fired steam plants on the coast, $200 \mathrm{MW}$ of gas turtines, and $100 \mathrm{MW}$ of diesels. To meet 
this goal, Soneigaz will need to build an average of $600 \mathrm{MW}$ of generating capacity each year along with additional high voltage transmission lines.

\subsubsection{Mauritius}

This republic in the western Indian Ocean consists of the islands of Mauritius, Rodrigues, and Agalega, and the Saint Brandon Group. The country has a single utility - Central Generating Board (CEB) which generates and distributes electric power. In 1991, it had a total capacity of $235 \mathrm{MW}$, producing $425 \mathrm{GWh}$. Diesels supply power at the Fort Victoria and St Louis plants. The remaining capacity comes from six hydroelectric stations; the newest, Champagne, at $30 \mathrm{MW}$ is the largest. Selfproducing sugar estates own another $15 \mathrm{MW}$; CEB annually purchases about $40 \mathrm{GWh}$ from these facilities.

Morket Assessment. To meet future demand, CEB is investigating the construction of a bagasse-fired power plant. It has also scheduled rehabilitation of its small hydro plants.

\subsection{Market Assessment: Asia}

\subsubsection{Nepal}

The Nepal Electricity Authority (NEA) - comprised of what was the Nepal Electricity Corporation and the Electricity Department of Ministry of Water Resources - handles all aspects of planning, construction and operation of power plants in Nepal. In 1993, NEA had installed capacity of $277 \mathrm{MW}$. The largest plants in Nepal are the $69 \mathrm{MW}$ Marsyangdi and the $60 \mathrm{MW}$ Kalekhani I hydro stations. Other major hydro plants include Trisuli (21 MW), Gaudah (15 MW), Devighat (14 MW), and SunkOsihi (10 MW). Two hydro stations near completion are the Kulekhani II plant (32 MW) and the Andikerala plant (5 MW).

Utility production in 1993 was $936 \mathrm{GWh}$ with all but $61 \mathrm{GWh}(6.5 \%)$ generated by hydro. The Central region accounts for $72 \%$ of the nation's consumption, but has only $33 \%$ of the population. The Eastem region consumes $14 \%$ of Nepal's electricity and over $95 \%$ of this energy is imported from India. The Western, Midwestern, and Far Western regions consume Nepal's remaining $9 \%, 3 \%$ and $2 \%$ of electricity, respectively.

The electrical systems in the Central and Western regions are interconnected. NEA is linking its six small hydro stations, as well as interconnecting the Eastern region to the Central and Midwestern regions.

Morket Assessment. A current challenge for Nepal is the cost-effective, environmentally-acceptable utilization of its tremendous hydropower resources estimated to be in excess of $42 \mathrm{GW}$. With the cancellation of Arun 3 by the World Bank, when it determined that several smaller projects could produce the electricity more cheaply (than $\$ 3800 \mathrm{KW}$ ), the Nepalese government tumed to the private sector to build its new power plants. In 1993, the government approved a new legislative and legal framework to faciliatate private power development and established an Electric Development Center to serve as a "one stop shop". In early 1995, the government of Nepal announced that it had 1,720 MW of hydroelectric projects available for private sector investment, in addition to several hundred "mini" projects of $100 \mathrm{~kW}$ to $1 \mathrm{MW}$. 


\subsubsection{Laos}

Laos is Southeast Asia's only landlocked country. Mountains cover about $90 \%$ of the country. Laos exports over $80 \%$ of its electricity to Thailand, and these sales provide about one-half of the country's foreign exchange earnings. The state-owned utility, Electricite du Laos (EDL), has a $261 \mathrm{MW}$ capacity - $190 \mathrm{MW}$ of which is at Nam Ngum hydro plant in Vientiane province; $45 \mathrm{MW}$ comes from a new hydro station near Saravane on the Xeset River, small hydro plants account for another $3 \mathrm{MW}$; and diesel units make up the remainder. These small stations are scattered throughout five city systems: Luang Prabang, Pakse, Thakhet, Savannakhet, and Vientiane. Both Thakhet and Savannakhet import supplies from Thailand. Country-wide electricity production totaled $900 \mathrm{GWh}$ in 1993, but consumption was only $293 \mathrm{GWh}$.

Market Assesoment. The main populations centers in Laos have access to electric transmission lines; in the near future, EDL plans to extend its transmission and distribution system to reach the country's southem and central provinces. Due to its central position - vis-a-vis the rapidly-growing Thailand and potential improvements in Vietnam - the Lao government is receptive to private development of its considerable hydro potential, estimated to be $20,000 \mathrm{MW}$. Two projects on the Nam. Theun River are planned: Nam Theun 2 is a $600 \mathrm{MW}$ plant under development with two Australian concerns; Nam Theun 1, a $210 \mathrm{MW}$ plant designed for export to Thailand, is under discussion with a ScandinavianThai consortium. A third project is the $150 \mathrm{MW}$ Hauay Ho plant, under construction on the Ho River in Champassak Province. While resettlement is not an issue with any of these hydro projects, due to the small Laos population, the major opposition to these schemes is from environmentalists concerned about the affect on fish brood stocks.

\subsubsection{Bangladesh}

Consumers in this densely populated country have limited access to electricity as supplies from the state-owned utility, Bangladesh Power Development Board (BPDB), reaches only 14\% of the population. Electric power outages are frequent in Bangladesh due to aging power plants and distribution facilities; periodic floods and cyclones compound these supply problems.

The majority of the energy resources used for power generation - hydroelectric and natural gas - are located in the East. BPDB's capacity is $2,560 \mathrm{MW}$; it produces approximately 5.7 TWh per year, with over $50 \%$ from natural gas-fired facilities. Electricity sales are predominantly in four major metropolitan areas: Dhaka, Chittagong, Khulna, and Rajshahi. Transmission and distribution losses are estimated to be as high as 35\%. The major transmission line - the East/West Interconnector - is energized at only $50 \%$ because other necessary facilities are unavailable. When fully energized this 500-MW transfer capacity will enable BPDB to reduce generation in the West, although some of the oil-fired generators will continue to operate in case of single-circuit tripping of the Interconnector.

Market Assessment. To meet the increasing demand for electricity, growing at up to $12 \%$ per year, BPDB has estimated that 2,500 MW of new capacity must be added by the year 2000 , with another $6,000 \mathrm{MW}$ between 2000 and 2010. Given the government's lack of funds and the generally slow pace of private power development in South Asia, the addition of 10,000 MW of new power plants in the next 15 years seems unlikely.

Nonetheless, the government has defined a two-part strategy to develop new power projects. With the help of the Asian Development Bank ( $\mathrm{ADB}$ ), a provisional power sector reform plan was developed at the end of 1994 with the immediate goal of building a $300 \mathrm{MW}$ gas-fired combined cycle plant in Meghnaghat. The country's Ministry of Energy \& Mineral Resources (MEMR) has also 
suggested several other sites and fuel schemes that it deems appropriate for private power projects and the government hopes that $2,300 \mathrm{MW}$ of private power projects will be developed on a build-operatetransfer (BOT) basis. These developments will not happen without tariff reform, since the lowest tariff charge is lower than the least-cost generating facility.

Beyond Meghnaghat, a second proposed plant would fire coal-bed methane from fields near Jamalganj, while a third plant would bum petroleum products from the natural gas fields of Bakhrabad. A fourth facility is a $300 \mathrm{MW}$ power plant that would use coal from the Barapukuria-Peerganj region in the Western zone. International financing is being pursued by Bangladesh for these and other proposed power plants. The key element in the overall Bangladesh strategy is to have developers ease the burden on the public supply by siting large plants at the nation's refineries, where they could bum surplus production of oil and naphtha. Other parts of the strategy include the establishment of freetrade zones to be served by smaller plants, and the leasing of captive capacity to BPDB.

Finally, a rural electrification program initiated in 1994 is scheduled to link 2000 villages with the national power grid. Thity-five percent of the project cost is being paid by the Bangladesh government, with the remainder from donor agencies. Related to this electrification program is the formation of the Rural Power Company (RPC); RPC was formed from existing electric power cooperatives to accelerate rural development. Partial ownership of RPC resides with the government's Rural Electrification Board, which has promised to sell some its holdings on the stock exchange after 1997. Currently, the RPC has plans for a $60 \mathrm{MW}$ gas-fired power plant at Mymensingh.

\subsubsection{India}

India is the second most populous nation in the world with a large but struggling electric power sector. Growth in the period 1990-1995 was $9.4 \%$, with an average growth rate of $7.5 \%$ projected for the period 1995-2000. Installed "All India" capacity (in March 1993) was estimated to be 72,320 MW", but only approximately $65 \%$ is typically available on-peak. "All India" thermal generation in $1992 / 93$ was about $225 \mathrm{TWh}$.

Three types of utilities operate in India: the State Electricity Board (SEB); Licensees; and governmentowned generating companies. The SEBs - of which there are about 12 - control $65 \%$ of the country's installed generating capacity. For those projects too large or complex for individual SEBs to develop, the government formed several "Central Sector Power Corporations", including: National Thermal Power Corporation (NTPC) - India's largest single plant operator, the National Hydroelectric Power Corporation (NHPC); the North Eastern Electric Power Corp (NEEPCO); the National Power Transmission Corp (NPTC); and the Nuclear Power Corp. Since India intends to form a national grid the government decided to transfer all transmission assets of the central sector power utilities to the newly formed NPTC and renamed it the Power Grid Corporation (PGC).

Deliverability of adequate supplies of electricity in India is hampered by equipment availability and T\&D losses. The NTPC, India's largest utility with 13,054 MW of installed capacity, reported a $1992 / 93$ load factor of $70 \%$, compared to the "All India" thermal plant load factor of $57 \%$. Increasing the load factor of SEB baseload units is a major planning objective.

NTPC has ambitous plans to increase capacity and improve supply. It is building four super thermal plants at Singrauli (2,000 MW), Korba (2,100 MW), Ramagundam (2,100 MW), and Farakka $(2,100$

${ }^{3}$ Excludes $6,250 \mathrm{MW}$ of autoproducer capacity and 2,900 MW of capacity operated by five private utilities. 
MW). Altogether, NTPC has 10 coal-based projects and five gas-based combined cycle power projects on-line or in development with a total approved capacity of 16,835 MW. Since 1980, NTPC has commissioned 13,054 MW.

Development of new hydroelectric plants is planned by the NHPC and the SEBs. NHPC is presently building new hydro units and has plans for six more (totaling 3,730 MW). The SEBs are also seeking 19 new hydro stations $(2,073 \mathrm{MW})$. The Nuclear Power Corporation confronted with budget reductions and success with indigenous plant designs and manufacturing, has scaled-back its ambitous plans for $10,000 \mathrm{MW}$ of nuclear capacity by the year 2000 , and will instead concentrate on completing six $220 \mathrm{MW}$ pressurized heavy water reactors (PHWRs) and starting construction on its $500 \mathrm{MW}$ design.

Faced with continuing power shortages, many Indian utilities have been exploring private power development in their service territories. The Indian Ministry of Power solicited third-party ownership of new capacity by proposing amendments to its electricity legislation in January 1991. This legislation allows private companies to install their own capacity and/or distribute electricity as a licensee of the SEBs; sale of surplus power from industrial plants is also permitted. Since privatization of the SEBs is unlikely in the near-term, international private power companies will likely invest in power plants rather than utilities.

There are currently five private power utilities in India with installed capacity of approximately 2,900 MW; an additional 6,250 MW is available from autoproducers ( $9 \%$ of "All India" capacity). Estimates of the private power in India range up to $21,000 \mathrm{MW}$ by the turn of the century, but at this point, only private utilities have built "private" plants. The largest "pure" private power projet in India was is the Dhabol combined-cycle plant ( $3 \times 660 \mathrm{MW})$ under construction by Bechtel, Enron, and General Electric.

Market Assessment. India is a very large power market. Due to its high growth in electricity demand - past, present and future - large power projects have been proposed to meet this demand. While the NTPC and the NHPC have many large projects under development, private power projects for the SEBs is likely to be the source of most new capacity additions, once the Dhabol situation is resolved. Besides traditional fuels for large power plants (coal, oil/gas, nuclear), India - like China and other Asian countries - is trying to develop small amounts of "alternate fuel" generating capacity. While many comparisons between the Indian and Chinese electric power markets are made, there are significant and inexplicable differences between the power sectors of the two countries. One notable difference is that the Chinese have added new generating capacity at a more rapid pace: installed capacity in India today is only about half that in China and the gap is widening. This has left per capita electricity consumption in India at about $65 \%$ of that in China. Compounding the large power needs is the absence of a fully-integrated network, large variations in transmission line voltage and substantial $T \& D$ losses, which impact deliverability, reliability and rural electrification.

\subsubsection{China}

China is currently the third largest producer and consumer of energy in the world. Within Ching the Ministry of Electric Power (MOE) is responsible for policy direction, technical guidance and oversight of the power sector. The MOE estimates demand growth of $7-8 \%$ per year for the next 10 years (or more), after double-digit growth during the past five years. Heavy industry continues to be the biggest consumer of electricity in China at $61 \%$ (1993), with "light" industry the next largest sector at $16 \%$. In 1993, electric power accounted for $32 \%$ of total primary energy consumption, almost double its share in 1980. As a reflection, new capacity additions have been averaging $15-20 \mathrm{GW}$ a year, this rate of 
capacity expansion is expected to continue through 2005. In its ninth five-year plan China outlines a plan to increase installed electric generating capacity from $199 \mathrm{GW}$ in 1994 to $300 \mathrm{GW}$ by 2000,400 GW by 2010 , and $800 \mathrm{GW}$ by 2020 .

Under the direction of the MOE are the following electric power systems: national corporations for coal oil and nuclear operations; five regional electric power corporations; and approximately 12 supraregional utility organizations, with 18 provincial power grids reporting to them. Four of the regional power grids have capacities exceeding $25 \mathrm{GW}$; three of the other grids are over $10 \mathrm{GW}$. In addition many cities and provinces have their own power companies and there are several other state-owned entities set up to finance and/or construct power plants. However, the relationship between the city suppliers and regional utilities is often obscure.

Regional power networks - covering several provinces - are Central China, East China, Northeast, North China, and Northwest. Provincial grids are in Fujian, Guangdong, Guanga, Guizhou, Hainan, Shandong, Sichuan, and Yunnan. The remaining two systems - Xinjiang and Xizang - are in so-called autonomous regions. The regional networks and provincial grids are designed, constructed, and operated by the regional electrical enterprises.

Market Assessment. At present, $75 \%$ of Chinese generating capacity is thermal (predominantly coal), with the remaining share hydroelectric. This fuel-source distribution is projected to remain constant for the foreseeable future. China is currently developing a mega-hydroelectric plant, the $17,600 \mathrm{MW}$ Three Gorges project. In addition, other giant hydro plants recently completed or planned include: Xiaowan $(4,200 \mathrm{MW})$, Longtan $(4,000 \mathrm{MW})$, Tianshengqiao I \& II $(2,520 \mathrm{MW})$, Lijiaxia $(2,000$ MW), Manwan (1,500 MW), Suikou (1,400 MW), Wuquiangxi (1,240 MW), and Dachaoshan (1,260 MW). Ertan (3,300 MW) is being built with substantial Western equipment and engineering services as was the Guangzhou pumped-storage plant ( 4 × $306 \mathrm{MW}$ ) completed in 1994. A second 1,200 MW plant is planned for service in 1999 . Several other pumped-storage plants are under development with Westem technology: Shisanling ( 4 × 204 MW), Tianhuangping ( 6 × 300 MW).

There are also many large thermal plants planned or recently completed. Many of these plants are located in Shanxi Province, including the Yangcheng ( $8 \times 660 \mathrm{MW})$ minemouth plant. In addition, 4,000 MW plants are under construction at Taishan and another plant at Ymin in Tibet. In all, China has 40 plant sites at which more than 1,000 MW of capacity is planned or installed; some of these sites are considering installation of clean coal technologies.

There are several reasons for the Chinese emphasis on central station developments. First, there is a large base of domestically constructed units standardized at 50,100,200 and $300 \mathrm{MW}$; and Chinese fabrication and manufacturing facilities are designed for these sizes. Second, coal and nuclear - the technologies of choice in China - are most cost-effective in large units. Third, the Chinese believe that centralized facilities allow the most efficient use of economies of scale for labor and other resources. Fourth, large amounts of power are needed quickly. While most of the emphasis is on large plants, the small-plant business is extremely active; one equipment supplier estimates that $10 \%$ of the installed capacity in China are diesel engines.

While the power sector opportunities in China are immense, the obstacles can be formidable. Some of the obstacles that relate directly to small-power production include: First, there is often insufficient revenue from electricity sales to support power plant investment; recent tariff increases are still below the actual cost of production and transmission, this is particularly true in remote areas. Second, China is a large country - almost 10 million $\mathrm{km}^{2} ; 1.2$ billion people live in urban areas along the coast and major rivers, and several hundred million people live in remote rural locations. Third, per capita 
electricity consumption is approximately $650 \mathrm{kWh} / \mathrm{yt}$ (compared to worldwide average of 2,300 $\mathrm{kWh} / \mathrm{yr}$ ), and many rural residents have no access to electricity. It is difficult (to impossible) to accurately predict future electricity growth and capacity needs to serve households with these characteristics.

\subsubsection{Pakistan}

Pakistan had a total generating capacity of about 11,581 MW in 1994, but shortages at peak periods reached 2,000 MW. Approximately 1,750 MW (15\%) is from autoproducers, with the remainder owned by Pakistan's two big utilities: Water and Power Development Authority (WAPDA) and Karachin Electricity Supply Corp (KESC). Of the total, $70 \%$ is thermal, $29 \%$ hydro, with a single nuclear plant that provides $1 \%$. Oil and gas are the dominant fuels representing $55 \%$ and $42 \%$ of thermal capacity, respectively. Coal is only marginally used, although there are substantial reserves. At present, electricity is currently available to about $40 \%$ of the population.

As of 1991, WAPDA had an installed capacity of 7,039 MW (59\% thermal, $41 \%$ hydro); KESC had 1,540 of installed capacity (1993). The big hydro plants at Tarbela (3,478 MW), Mangla (720 MW) and Warsak (240 MW) in northern Pakistan are connected to load centers and to the large thermal plants at Guddu (1,154 MW), Kot Addu (440 MW), and Jamshoro (880 MW).

Severe power shortages have existed in Pakistan for decades, which is the result of power plant and transmission inefficiencies and a double-digit growth rate for power. A drought in 1993/94 reduced output from the county's two largest hydro plants by $30 \%$, and even with newly commissioned capacity, load shedding for up to seven hours per day was reported in 1995. Pakistan has proposed that 13,000 MW of new capacity be added, with one-third coming from private power.

Pakistan became the first developing country to provide for private power development, when it promulgated a new policy permitting private power participation in plant construction and operation in 1985. The 1,300 MW Hub River project ( $4 \times 325 \mathrm{MW})$ now under construction by a private consortium was originally scheduled for startup in 1994; Hub River is now scheduled to be commissioned in 1997.

Market Assessment. Pakistan is blessed with fairly large reserves of natural gas (estimated to be approximately $21,000 \mathrm{bcm}$ ), together with 288 million tons of coal and lignite reserves (although much of it is classified as poor quality), and $30,000 \mathrm{MW}$ of hydroelectric potential (10 times the installed base). Therefore, the quantity and diversity of fuel for power production is not an issue.

Major utility power projects in Pakistan include completion of Tarbela (two of four new $432 \mathrm{MW}$ units began operation in 1993), two $100 \mathrm{MW}$ units at Mangla, and eight $22 \mathrm{MW}$ low-head hydro units at Chasma. At Kot Addu, a $450 \mathrm{MW}$ combined cycle block is coming on-line, while KESC plans to build a $210 \mathrm{MW}$ addition at Bin Qasim (Unit 6) by 1196 and a $300 \mathrm{MW}$ addition is under study at Korangi (Unit 5). Other new steam capacity is planned or under construction at Jamshoro and Muzza-Fargah ( $2 \times 210$ MW by Chinese suppliers).

China National Nuclear Corp broke ground in 1992 for a 300 MW nuclear unit at Chasma; startup is scheduled for 1998. The World Bank is examining the possibility to provide financial assistance in the recently initiated 1,450 MW Ghazi Barodaa on the Indus River, plans exist for two additional hydro plants, including Basha $(3,360 \mathrm{MW})$ and Kalabagh $(2,400 \mathrm{MW})$. 
The government of Pakistan believes that 14,500 MW of new capacity must be added by 2000 to fill the aurrent supply gap and meet future electricity demand, forecast to continue growing at $10 \%$ per year. Pakistan would prefer that the private sector development most of this capacity, by constructing 2,000 MW per year, equally divided between coal, hydro and oil-fired capacity. Judging by the Hub River experience, it is difficult to predict whether utilities or private power will be the dominant force in meeting this demand.

As in most other developing countries, plant utilization is an issue for utility management. Pakistan recognizes that increased utilization factors (which are related to increased reliability of the $T \& D$ system), expansion of cogeneration, and expanded market services, would all increase available capacity. To this end, Pakistan has announced restructuring plans for the utility sector. The strategy is to 1) urge existing industrial plants to install their own generating plants; 2) facilitate foreign investment in industrial parks where captive generators can sell surplus power to the national grid; and 3) privatize all or parts of WAPDA and the government's stake in KESC. None of this, however, will occur without effective tariff reform.

\subsubsection{Sri Lanka}

Sri Lanka is an island republic in the Indian Ocean off the southeastern coast of India. The Ceylon Electricity Board (CEB) is the sole state authority responsible for generation and transmission, and a large share of the distribution of electricity on the island. The Lanka Electricity Company (LECO) is responsible for distribution on the southern and western coastal areas. At the end of 1993, CEB had a generating capacity of $1,409 \mathrm{MW}$, of which $80 \%$ was hydro with the remainder a mix of oil-fired steam turtines, gas turbines, and diesels.

Morket Assessment: The island grid is interconnected and with the addition of a large hydroelectric plant on the Mahaweli River, the CEB has an adequate reserve margin. About one-half of the hydro potenial on Sri Lanka is being utilized; however, in order to diversify its fuel mix the government is shifting toward the construction of thermal plants.

Sri Lanka is hoping for private sector investment, because the World Bank and Asian Development Bank are reluctant to make further loans to the CEB for conventional power generation. Loans for DSM and power delivery projects are still being considered since $70 \%$ of the island households $(300,000)$ still have no access to grid electricity. One private power project, being constructed on a BOT basis is the 300-MW facility at Trincomalee. Other private projects planned by the CEB include 44- and 204-MW powerplants at Kotmale Oya.

\subsubsection{Indonesia}

Indonesia, the fifth most populous country in the world, is rich in many natural resources, including coal, oil, gas and timber. Less than one-half of the country's 13,000 islands are inhabited. Sixty percent of the population (187 million) reside on the main island of Java; 8.8 million in Jakarta.

4 Since almost all generation and transmission equipment is imported devaluation is important; the nupec has declined in value (relative to the U.S. dollar) from 10:1 in 1980 to $31: 1$ in 1995. In addition, cross-subsidization is an issee, whre commericalindustrial customers are being charged electricity rates that approximate marginal delivered costs, while residential customers are paying one-half the recovery rate, with many paying nothing at all. Lastly, WAPDA and KESC have attempted to equalize tariffs, eventhough WAPDA is hydro-dominated and KESC serves mostly an urtan emvironment with thermal plants. 
The national electric utility is PT PLN Persero - formenty known as Perusahaan Umum Listrik Negara (PLN). PLN has engineered a five-fold increase in generating capacity since 1970; in addition, electricity sales have increased by $32 \%$ per year since 1980 (6.5 TWh in 1980 vs. 27.7 TWh in 1990). Total PLN electricity production in 1991 was approximately $30.3 \mathrm{TWh}$ (68\% of total generation); this was supplemented by autoproducers who provided an additional $14.4 \mathrm{TWh}$. Even with all of this capacity and sales growth, less than 10\% of the Indonesian population - scattered among seven island groups - has access to power supply.

Indonesian power demand is projected to increase by about $15 \%$ per year. At present PLN is meeting demand with 9,100 MW of installed capacity, consisting of steam-electric (43\%) and hydroelectric (23\%) plants. Due to the fragmented nature of its service territory, diesel power plants are numerous and comprise approximately $20 \%$ of capacity. In addition, PLN has about $140 \mathrm{MW}$ of installed geothermal capacity that supplies $3.2 \%$ of the country's output. The remaining $13 \%$ of capacity is in gas turbines, but this is the fastest growing segment of PLN capacity.

Indonesia is one of the world's major oil exporters and the largest exporter of LNG. Together these fuels provide some $40 \%$ of total export revenue, and the government is intent on maintaining high levels of export for as long as possible. With domestic oil consumption increasing at about $5 \%$ per year, and little prospect of major new discoveries, Indonesia may cease being a major oil exporter early next century. This leaves coal and gas as the fuels of choice for power generation; and gas exports via LNG - may replace oil as the means for government revenue generation in the future.

Indonesia coal reserves are estimated at 32 billion tons, much of it high quality. Coal production in 1993 was 28 million tons/year, with exports accounting for 19 million tons. Several large coal-fired power stations have recently been completed or are under construction on East Java; most notably Paiton, where the first project financed $2 \times 600 \mathrm{MW}$ units were constructed and another $2 \times 600$ set is under construction. Besides coal, natural gas is the next most desirable fuel for power generation. Indonesia has proven reserves of 74 tcf and gas production of 2 tcf/year, half of which is currently exported to Japan as LNG; LNG exports to Korea and Taiwan are also under development. The remaining gas is burned in large gas turbine and combined cycle power plants such as Gresik (1,500 MW), Tanjung Priok (1,200 MW), and Tambok Lorok (500 MW). These, and other smaller gas plants, have developed since they could be constructed faster and at a lower capital cost than coal-fired power stations to meet the rapid growth in electricity demand.

Indonesia also has substantial hydroelectric resources - perhaps as much as 35,000 MW - but it is mostly located in Irian Jaya and Kalimantran, far from load centers. Another renewable resource, geothermal, could have up to 10,000 MW of viable capacity. Several hundred megawatts of geothermal power is under development by PLN, with approximately $500 \mathrm{MW}$ available for private power.

Market Assessment: With Paiton as the flagship project, the Government of Indonesia (GOI) hopes to add 10,000 MW of new capacity from 1995-1999, largely from private power entities. The second phase of Paiton ( $2 \times 610 \mathrm{MW}$ ) is currently under development by Mission Energy, with a second pair of $600-\mathrm{MW}$ units to be built by a team led by Siemens. Electricity costs for the Mission Energy plant are front-end loaded starting at 8.56 cents for the first six years, dropping to 5.54 cents in the final 18 years. PLN's average tariff is about 6.6 cents at present.

Indonesia needs new capacity very badly, but the government and PLN are financially strapped, and privatization of PLN appears unlikely. So, private power holds considerable promise if bidding and financial arrangements can be more transparent and open. In addition, PLN cash flow would be greatly 
improved if tariffs could be raised. Compounding these matters, PLN hopes to install thousands of new low- and medium voltage transmission lines to rural areas, with the goal of electrifying 2,500 Indonesian villages.

\subsubsection{Myanmar}

The state-owned utility Myanma Electric Power Enterprise (Mepeum) holds an effective monopoly on electricity supply in Myanmar (Burma). Generating capacity in 1993 was 1,151 MW consisting of hydroelectric plants, oil-fired steam turbines, gas turbines, and isolated diesel units. The $196 \mathrm{MW}$ Lawpita hydroelectric plant on the Irrawaddy River provides the bulk of Mepeum's supply, which totals $980 \mathrm{MW}$ ( $85 \%$ of country-wide generating capacity). Total generation in 1993 was $3.2 \mathrm{TWh}$, roughly one-third from Lawpita. Mepeum operates three grids interconnected by $230-k V$ line, which enables the transfer of excess capacity from one system to another.

Market Assesoment: Hydroelectric resources in Myanmar are immense, estimated at 108,000 MW. To meet long-term energy demands - and possibly serve an export market - Mepeum has several hydroelectric stations under consideration, either for its own development or for construction by private power developers. These include Paunglaung (280 MW), Bilin (240 MW), Kunchaung ( 84 MW), Baluchaung (28 MW), Zaungtu (18 MW), and Yenwe (16 MW). The country's other energyproducing resources include 145-billion barrels of oil, $289 \mathrm{bcm}$ of natural gas, and 119-million tons of subbituminous coal.

Reportedly, Chinese and Thai developers are actively involved in developing several of the hydroelectric sites for power export. China has agreed to construct the Paunglaung plant (280 MW); a $6,000 \mathrm{MW}$ hydro plant on the Salween River has been discussed, with $80 \%$ of the electricity exported to Thailand. Finally, a Thai logging company has signed a MOU to build two hydro plants in Shan State with a total capacity of $125 \mathrm{MW} ; 90 \%$ of this power would be exported to Thailand.

\subsubsection{Vietnam}

Since 1992, the Vietnamese economy has been growing at about $8 \%$ per year. This is largely attributed to a gradual transition from a centrally-planned to a market economy. Over the next five years, electricity demand is expected to grow at a faster pace than the economy, $12-14 \%$ per year. Long-range forecasts published by the Ministry of Energy estimate domestic power demand of 110 TWh by 2015 , a ten-fold increase from 1994 levels of $12.7 \mathrm{TWh}$. To generate this electricity, investment of $\$ 7.5$ billion is needed: $\$ 6$ billion for generating facilities and \$1.5 billion for T\&D projects.

Currently, $75 \%$ of Vietnam's electricity is from hydro plants, the largest of which at Hoa Binh (1,930 MW) was completed at the end of 1994, with thermal plants accounting for $17 \%$ of output and gas turbines the remainder. In 1994, Vietnam had total installed capacity of 4,100 MW. Completion of the Russian-supplied Hoa Binh hydroelectric plant increased electricity output by $15 \%$ from 1993 to 1994 . Vietnam hopes to export surplus power to Laos and perhaps China (southern provinces) to help defray the cost of its power system expansion.

Until recently, Vietnam had three government-owned power companies operating under the auspices of the Ministry of Energy: Power Company No. 1 served the northern region, Power Company No. 2 served the southern region, and Power Company No. 3 served the central region. In 1995, these three power companies were consolidated into a new entity called Electricity of Vietnam. The generating capacity that comprises Electricity of Vietnam is a mixture of vintages and manufacturers: Russian and 
Eastern European manufacturers in the north, and American and Japanese in the central and southern regions.

Although as yet largely undeveloped, Vietnamese energy resources are substantial and currently account for approximately one-third of the country's export eamings. Estimates of hydroelectric potential are as high as $15,000 \mathrm{MW}$, with 2 billion tons of coal, 170 million tons of oil and $106 \mathrm{bcm}$ of natural gas.

Market Assessment: Due to its large hydroelectric resource, Vietnam expects much of its future electricity capacity to be hydraulic. Several sites are already under development along the Dong Nai River: Bonron (320 MW), Can Don (60 MW), Da Mi (172 MW), Dong Nai 4 (250 MW), Dong Nai 8 $(120 \mathrm{MW})$, and Nam Thuan (300 MW). A number of thermal plants are also under construction: Phu My 2 Phase 1 (200-300 MW gas turbine); conversion of three 37.5 MW gas turbines to combined cycle plants at $\mathrm{Ba} \mathrm{Ria}(170 \mathrm{MW})$; and rehabilitation and conversion of the Thu Duc plant to gas.

Since Vietnam cannot afford to make all the necessary investments itself, foreign companies are expected to construct some of the new generating capacity; one captive power project is being jointly developed by BHP (Australia) and General Electric (U.S.) at a new fertilizer complex near Ho Chi Minh City. Vietnam also hopes to interconnect the country through the formation of a master plan for rural electrification.

\subsubsection{Philippines}

The Philippines has a population of 65 million spread over 7,100 islands; it therefore resembles Indonesia insofar as infrastructure requirements, but lacks the large oil and gas reserves. Philippines is also unique in Asia (with the exception of Japan) as having the most diverse and advanced electric utility system.

National Power Corporation (NAPOCOR) is a large Phillipine utility that provides almost all of the utility-owned generation to the three principal islands: Luzon, Visayas, and Mindanao. However, NAPOCOR is more of a power wholesaler than a retail utility. The Philippines is divided into six separate grids corresponding to the main island or island groupings of Luzon, Mindanao, Cebu, Negros-Panay, Leyte-Samar, and Bohol. The single largest electricity distributor is Meralco, the privately-owned distributor for four cities - Manila, Quezon City, Coloocan, and Pasay - and adjoining municipalities commonly referred to as Metro Manila, which sells approximately $75 \%$ of NAPOCOR's generation. There are about 15 other private or municipal utilities in the country. In addition, there are 120 rural electric cooperatives, whose operation is overseen by a separate government agency, the National Electrification Administration (NEA).

Rural electrification programs are vital to stem the urbanization tide that threatens to overwhelm many rapidly-growing Asian cities. The Philippine program is very aggressive: by 1992 (after 23 years), cooperatives were serving 3.2 million consumers with electrification levels of $60 \%$. The goal is for $77 \%$ electrification by 2000 . This is viewed as an ambitious target, and given recent financial and operating problems, will only be achievable with attention to fundamentals and the availability of sufficient electricity.

Market Assessment: While there are sufficient coal reserves to support some expansion of coal-fired generating capacity, they are not located near current load centers. With limited oil/gas reserves, the Philippines will probably expand its already significant geothermal power plant capacity (presently $22 \%$ of NAPOCOR output). There is an active auto producer (i.e., captive power) segment, and there is 
considerable potential for alternative fuel development. One possibility is bagasse (sugar cane waste) combustion at sugar mills; solar power may aiso assist in the electrification of remote areas. Still over $50 \%$ of utility generation is oil-fired, further exacerbating balance-of-payment problems.

In the near-term, NAPACOR is hoping that private power developers will construct most new projects. Since 1987, when the government invited private sector investment in power generation there has been a positive response; in 1994 alone, 1,600 MW of private power was built together with $150 \mathrm{MW}$ of utility capacity. ${ }^{5}$ To respond to peak power demand, NAPOCOR has also built a number of power barges with big diesel engines and simple-cycle turbines.

The government estimates that $20,698 \mathrm{MW}$ of capacity additions are needed to meet demand in the 1993-2005 period. The new capacity will likely consist of: hydro 1,872 MW; geothermal 1,673 MW; coal 12,400 MW; and oil/gas 4,753 MW.

\subsubsection{Papua New Guinea}

The Electricity Commission (Elcom) is the principal electric utility in Papua New Guinea. It owns and operates 19 discrete power systems; the two largest are in Port Moresby and Ramu. In 1992, Elcom had total capacity of $252 \mathrm{MW}$ and generation of $624 \mathrm{GWh}$. On Ramu, capacity is $111 \mathrm{MW}-87 \mathrm{MW}$ are hydro and $24 \mathrm{MW}$ are in the form of diesel and gas turbines. The Port Moresby system has an installed capacity of $105 \mathrm{MW}$, of which $62 \mathrm{MW}$ are hydro and $43 \mathrm{MW}$ are diesel and gas turbines.

Market Assessment: Baseload capacity is served by hydroelectric capacity; there is an estimated 15,000 MW of future potential. Grid connection in both Port Moresby and Ramu is extremely difficult due to the topography.

\subsubsection{Thailand}

The Electric Generating Authority of Thailand (EGAT), the major power generator in Thailand, had $12,900 \mathrm{MW}$ of capacity in $1994 ; 47 \%$ thermal, $32 \%$ combined cycle, $20 \%$ hydoelectric and $2 \%$ simplecycle turbine. During 1994, peak demand was $10.7 \mathrm{GW}$, a $10 \%$ increase over 1993, but considerably lower than the $14 \%$ rate experienced between 1987-1991.

EGAT has over 3,100 MW of new capacity under construction or committed; by the year 2011, EGAT hopes to have $44,000 \mathrm{MW}$ available to the grid. This represents the addition of $1,000-1,500$ MW per year. Of this $75 \%$ is expected to be thermal plants, $15 \%$ combined cycle, with the balance hydro and simple-cycle turbine plants. In 1992, EGAT had the following fuel distribution for power generation: natural gas (44\%); lignite (20\%); heavy fuel oil (28\%); and hydro (5\%).

Lignite consumption is expected to increase when EGAT completes the two additional $300 \mathrm{MW}$ units

s One of the firs private power plants in Asia was built at Navotas near Manila $(3 \times 70 \mathrm{MW})$ by Hopervell Holding Company in 1991; a fourth unit was added in 1993, and Hopewell is now building a $700 \mathrm{MW}$ coal plant ( $2 \times 350$ MW) at Pagbilao, and a larger, 1,320 MW coal-fired plant at Sual in Pangasinan Province (2 x $660 \mathrm{MW}$ ). Other completed private projects include: hydro plants in Banguet Province (22 MW); three diesel plants developed by Enron (241 MW); two combined cycle blocks at Limay Bataan ( 2 × $300 \mathrm{MW}$ ); a refurbished hydro plant at Binga (100 MW); and a variety of ocher diesel power plants. Private power developers are also active in the development of geothermal power, one prominent participant is the Philippire National Oil Co. (PNOC) which is working on a $120 \mathrm{MW}$ plant at Mount Apo and $660 \mathrm{MW}$ in two blocks at Tongonan, Leyte. 
at Mae Moh (2,600 MW). A severe air pollution episode at the plant induced EGAT to install FGD scrubbers on the newest units; it was also forced - by public pressure - to cancel the proposed Ao Phai plant $(4 \times 700 \mathrm{MW})$. Severe air pollution in the capital also caused EGAT to switch to low-sulfur fuel oil in its urban plants and to natural gas combined cycle at its newer plants, such as the 1,200 MW Wang Noi. There is also environmental concern over the construction of new hydroelectric facilities; EGAT was forced to redesign the dam a Pak Mun to minimize displacement of local residents.

The Metropolitan Electric Authority (MEA) distributes the power produced by EGAT througout Bangkok, and the provinces of Samutprakam and Nonthaburi. The Provincial Electric Authority (PEA), aided by a small number of diesel engines, supplies rural areas and other cities with power.

Morket Assessment: Thailand's National Energy Policy Committee announced in early 1995 that Thailand will no longer build dams for power production. Rather, it will encourage importing electricity and promote private investment in other forms of electricity generation. EGAT was ordered by the Committee to cancel its plans to build two hydroelectric power projects (Kaeng Krung Dam in Surat Thani, and Mae Lamat Luang Dam in Tak) on the grounds that they would severly damage the surrounding environment and ecological systems. Such concerns will hamper any large-scale exploitation of the country's remaining $6,000 \mathrm{MW}$ of hydroelectric potential. As a result, natural gas is likely to be the fuel of choice for power generation.

Thailand has proven reserves of $6.4 \mathrm{TCF}$, and in 1994 the Petroleum Authority of Thailand (PTT) concluded an agreement to import gas from Myanmar's Yadana gas field, which has recoverable reserves estimated at 5.8 TCF. PTT is also looking to increase domestic production from the Gulf of Thailand and hopes to import up to 10 million tpy of LNG. This gas will be needed to offset the use of coal in power generation that may be stymied by environmental activism. In March 1995, EGAT cancelled Ao Phai and two lignite-fired plants at Mae Kham and Lampang.

To meet future power needs, private power options are emerging in Thailand. As an interim measure to full privatization, EGAT created a subsidiary called the Electricity Generating Company (EGC) and then in October 1994 sold it the Rayong combined cycle plant (1,200 MW). In addition, EGAT hopes to encourage additional production from autoproducers, who currently have $10 \%$ of the installed capacity, and private power developers, who were offered $3.8 \mathrm{GW}$ of projects for completion by 2002 .

\subsubsection{Malaysia}

Malaysia's relatively low population density, wealth of natural resources, and central location in the ASEAN have resulted in an expanding economy and large growth in electricity demand. The country's largest utility, Tenaga Nasional Berhad (TNB) which serves West Malaysia, expects power sales to increase by $10 \%$ per annum through 2000 . Estimates for peak demand of $9,500 \mathrm{MW}$ by 2000 correspond with capacity additions of $650 \mathrm{MW} / \mathrm{yr}$. By $1997, \mathrm{TNB}$ is planning to have $9,500 \mathrm{MW}$ of installed capacity, together with an additional $4,500 \mathrm{MW}$ from private power developers. Two other utilities serve the remainder of Malaysia: Sarawak Electricity Supply Corp (SESCO) and Sabah Electricity Board (SEB) provide electricity to the states of Sarawak and Sabah on the large island of Borneo (East Malaysia) that they share with Brunei and Indonesia. Overall, TNB produces about $90 \%$ of the electricity in Malaysia with installed capacity of 5,909 MW (1993).

Market Assessment: TNB has adopted a four-fuel strategy and is busy diversifying its fuel base. Coalfired capacity was introduced at two $300 \mathrm{MW}$ triple-fuel units constructed at Sultan Aziz. Currently, TNB has two large construction projects: a 600 MW hydroelectric plant at Pergau for service in 1996, and two 500-MW triple-fuel units at Sultan Aziz. TRB continues to order and build gas-turbine and 
combined-cycle power plants to avoid power shortages, as occurred in 1992. Recent projects include: conversion of GTs at Pasir Gudang and Paka to combined-cycle operation; a 220 MW GT plant at Malacea; a $330 \mathrm{MW}$ extension at Pasir Gudang; and six gas turbines at Kajang. In addition there are six private power projects totaling 4,000 MW slated for operation in 1996: a $720 \mathrm{MW}$ gas-fired combined cycle plant at Kuala Langat; two $405 \mathrm{MW}$ combined-cycle blocks at Paka and one $405 \mathrm{MW}$ block at Pasir Gudang; a 1,300. MW (2 x650 MW) combined-cycle plant at Lumut; a $440 \mathrm{MW}$ (4 x $110 \mathrm{MW}$ ) GT facility at Port Dickson; and four $123 \mathrm{MW}$ gas turbines at Teluk Gong. With all this new capacity the government of Malaysia has put a halt on new development while it reassess private power developments and the price offered - TNB reported signed contracts paying $\$ 0.06 / \mathrm{kWH}$, insuffucient to eam a profit on its own power investments.

Power plant construction is also underway in both Sabah and Sarawak. In Sabah, a refurbished 14 MW gas turbine was installed in 1993, while Sesco installed new turbine equipment at Kuching and Bintulu. In addition, on Sarawak with $20,000 \mathrm{MW}$ of untapped hydro potential, a phased development of 16,000 MW of hydroelectric capacity is planned at Bakun.

To interconnect the land areas, there are many transmission projects, including several submarine cable interconnections.

\subsection{Market Assessment: Central/Eastern Europe}

\subsubsection{Romania}

The Romanian Electricity Authority (RENEL), formed in 1990, has responsibility for most of the generation transmission, and distribution of electricity in the country. RENEL has installed capacity of 20,632 MW: 5,783 MW of hydro; 8,614 MW of lignite-fired; and 6,235 MW is oil- or gas-fired. Romanian autoproducers and other generators have an additional 1,400 MW. RENEL generated 53.8 TWh in 1994, with sales of 44.3 TWh. RENEL owns $96 \%$ of the installed generating capacity in Romania and provides $97 \%$ of its electric power.

Market Assessment: As with most Eastern European and FSU countries, the electric power industry in Romania has shrunk substantially as state-owned industries closed or were reorganized. Today, Romania has excess generating capacity and a poorly-developed subtransmission and distribution system. One notable sign is that while gross consumption declined to 2,453 kWW/capita (from 3,614 $\mathrm{kwh} / \mathrm{capita}$ in 1989), household consumption increased from $189 \mathrm{kWh}$ to $290 \mathrm{kWh}$ during that same period.

To meet future demand, Romania is attempting to complete its first (of five) $700 \mathrm{MW}$ nuclear plant at Cemavoda. RENEL also has $1,200 \mathrm{MW}$ of hydroelectric capacity under development, and 1,020 MW of thermal capacity. RENEL also hopes to modernize $5,800 \mathrm{MW}$ of existing capacity, $42 \%$ of the country's generating stock is over 20 years old and requires upgrading. RENEL is also trying to reduce its dependence on indigenous lignite; it hopes to use more natural gas and imported hard coal.

\subsubsection{Poland}

A state-owned holding company, Polske Sieci Elektroenergetyczne (PSE), was established in 1990 to handle dispatch, maintenance and development of the transmission system, electricity import/export, and coordination of power system development. The electricity dispatched by PSE is sold by 33 stateowned enterprises, while 37 generating companies operate most of the 33,171 MW of installed capacity (1994). Of this, $57 \%$ is in hard-coal fired plants, $27 \%$ in brown-coal plants and $3 \%$ in hydro 
stations. In addition to PSE, the Ministry of Industry and Trade, and Ministry of Privatization, also operate 13 hard coal generating companies and 21 hard coal CHP companies combined. Autoproducers have $6 \%$ of the country's generating capacity.

Morket Assessment: PSE estimates that Poland will need 5,100 MW of new capacity by the year 2000 and an additional 8-12,000 MW by 2010. Some of this capacity might be recaptured through efficiency upgrades. The government's long-term strategy includes the replacement of 3,000 MW of pulverized coal capacity by fluidized-bed boilers, gas-ired powerplants and the retrofitting of low-NOx burners on existing plants. This strategy also reflects a law passed several years ago requiring a $70 \%$ reduction in powerplant SO2 emissions by 1997. Four of the twelve brown-coal fired plants at Belchatow are being equipped with FGD units; a magnesium FGD units is being installed on a 100 MW boiler at the $550 \mathrm{MW}$ Skawina station.

\subsubsection{Bulgaria}

In 1993, Bulgaria had installed capacity of 12,000 MW (50\% thermal, 35\% nuclear, and $15 \%$ hydro). Production was approximately $45 \mathrm{TWh}$, of which nuclear supplied $12 \mathrm{TWh}(\mathrm{i} ; \%)$. The state-owned electricity company is Natsionalna Elektricheska Kompania (NEK). The overriding issue in the Bulgarian electricity sector is the country's nuclear power program: two of the four nuclear units at Kozloduy were built in 1974/75, are among the oldest of the Russian V-230 reactor design, and are in poor condition. Various financing and management arrangements have been proposed to resolve the issue, but replacing the nuclear capacity means increasing the utilization of the country's large lignitefired plants and their associated air pollution.

Market Assescment: Bulgaria hopes to build six new coal- and lignite-fired plants totaling 1,500 MW to replace obsolete equipment. The country also plans to install FGD units on two existing and all future coallignite-fired plants; it also hopes to convert several $50 \mathrm{MW}$ coal-fired boilers to fluidized bed combustion.

\subsection{Market Assessment: Middle East/Near East}

\subsubsection{Turkey}

At year-end 1992, Turkey had installed capacity of $18,714 \mathrm{MW}$, with $67.3 \mathrm{TWh}$ in generation. Electricity sales were about $55 \mathrm{TWh}$ with industry consuming $58 \%$. In 1993, the Turkish government issued a decree that split the Turkiye Elektrik Kurumu (TEK) - the state-owned enterprise (SEE) that had produced and distributed power throughout Turkey - into two separate public companies: Turkiye Elektrik Uretim-Iletim A.S. (TEAS) for generation and transmission, and TEDAS for distribution. TEAS has about 18,500 MW of installed capacity: $40 \%$ hydraulic and $60 \%$ fossil fueled (lignite $35 \%$; natural gas $16 \%$; fuel oil $8 \%$; and hard coal $2 \%$ ). TEAS also maintains high-voltage transmission links with Bulgaria, Georgia, Romania, and Russia Although hydro plants represent $37 \%$ of installed capacity, they account for up to $50 \%$ of generation in peak flow situations.

Turkey's largest powerplants include: 1,376 MW coal-fired Afsin-Elbistan; 1,340 MW hydroelectric Keban; 2,400 MW hydroelectric Ataturk; and two gas-fired combined-cycle plants at Ambarli near Istanbul (1,350 MW) and Hamitabat (1,200 MW).

While TEAS dominates the Turkish electric power supply industry, private entities are growing in importance. The major private power suppliers are Cukurova Electric in Adana and Kepez Electric in 
Antalya; between them they have $600 \mathrm{MW}$ of hydroelectric capacity. Cukurova has six hydro plants $(480 \mathrm{MW})$ and a combustion turbine plant at Mersin ( $4 \times 27 \mathrm{MW})$; Cukurova is considering converting Mersin to a combined-cycle plant and has obtained World Bank credit for a new $510 \mathrm{MW}$ hydroelectric plant on the Ceyhan River. Kepez Electric has three hydroelectric plants totaling 130 MW and is developing four additional hydroelectric projects (Beskonak, Alarahan, Esen and Sinanhoca).

Market Assessment: Electricity demand in Turkey is expected to increase to over $300 \mathrm{TWh}$ in 2010 , growth of about $8 \%$ per year. This would require generating capacities to expand to $33,400 \mathrm{MW}$ by $2000(178 \%$ from 1992 levels) and 58,000 by $2010(310 \%)$. In the near-term, Turkey plans to increase its production of fossil fuels (coal, oil, gas); double or triple its coal imports; and build additional gas transmission capacity from Russia. However, by 2010 , some forecasts indicate that indigenous oil/gas supplies will be depleted, forcing Turkey to rely increasingly on its lignite and hydroelectric resources.

Turkey is encouraging private power development, but so far progress has been slow; only the Izmir coal-fired power plant and a $227 \mathrm{MW}$ lignite-fired BOT project near Orta are proceeding. In its latest plan, Turkey envisions that $32,435 \mathrm{MW}$ of its planned $48,000 \mathrm{MW}$ expansion by 2010 will be constructed by private power developers.

\subsection{Market Assessment: Central/South America}

\subsubsection{Peru}

Peru is the third largest country in South America in land area and fourth largest in terms of population. Peru's electric-supply system is run by the state-owned Empresa Publica de Electricidad del Peru (ElectroPeru) and its ten regional subsidiaries. ElectroPeru has a total installed capacity of $2,700 \mathrm{MW}$, with hydroelectric stations (2,000 MW) accounting for $75 \%$ and thermal plants for the remainder. In 1993, about $80 \%$ of ElectroPen's output of $14.3 \mathrm{TWh}$ was hydro-based. Auto producers in Peru - largely copper, zinc, silver and iron-ore mines and smelters - have total installed capacity of $1,400 \mathrm{MW}$ ( $50 \%$ of ElectroPeru capacity), some of which is connected to the grid. Most of the autoproducer plants are oil-fired dieseis and steam turbine generators. Neither ElectroPeru nor the autoproducers bum any coal or gas; Pens now imports most of its oil, even though it has some 350 million barrels of reserves.

ElectroLima's capacity only suffices to satisfy one-half of the normal demand by metropolitan Lima; the remainder is provided by ElectroPeru. ElectroPeru and ElectroLima, which provide electricity to only $35 \%$ of the population, have not added a new hydroelectric plant in almost 20 years, and almost $50 \%$ of its themal capacity $(310 \mathrm{MW})$ is older diesel machines. Only a region called the North Central System is interconnected at the present time.

Market Assescment: Pen expects power demand growth to be $4 \%$ per annum. In response, ElectroPeru hopes to construct over $1,200 \mathrm{MW}$ of new capacity over the next ten years, $40 \%$ in new hydro plants and the balance in gas- and oil-fired thermal plants. Peru has about 74,000 MW of untapped hydroelectric capacity, when its rivers are flowing at normal levels. An expanded role for natural gas is contingent on the construction of a 500-mile pipeline linking the coast to Camisea - a large gas field discovered in the mid-1980s. Pen has very small coal reserves.

The ability of ElectroPeru and ElectroLima to met future generation needs is questionable due to lost revenue due to terrorist attacks (on transmission towers), low tariffs and high generating costs. In 
response, the stage has been set by the government for some of Peru's future capacity needs to be met by private power developers. Recent degrees (Supreme Degree 162-92-E and Degree Law 25844) repeal restrictions on foreign investment and permits the government to grant concessions to foreign corporations/individuals. Privatization of ElectroPeru and ElectroLima is proceeding, but the sale of assets have been deferred.

\subsubsection{Columbia}

Columbia has the third largest population in Latin America and is rich in energy resources. Initially all of Columbia's power plants were privately owned, largely by the mining industry. Today, Columbia has three state-owned utilities that generate power and perform other utility functions: Interconextion Electrica S.A. (ISA); Instituto Colombiano de Energia Electrica (ICEL); and Corporaction Electrica de la Costa Atlantica (Corelca). ICEL coodinates Columbia's national electrification plan and distributes power to rural areas through 13 electric companies it owns or controls. The two major municipal utilities are Empresa de Energia de Bogota (EEB) and Empresas Publicas de Medellin (EPM). EEB and EPM own approximately $15 \%$ of Columbia's generating capacity, respectively. Together they deliver power to $40 \%$ of the population.

Columbia has $9,400 \mathrm{MW}$ of installed capacity; almost $80 \%$ is hydroelectric, with $16 \%$ fossil steam and the remainder gas turbines and diesel power plants. Load growth is expected to expand at a rate of $6 \%$ per annum. To meet this demand, domestic utilities will have to add between 2,000-3,000 MW of capacity before $2000,60 \%$ of which is currently expected to be hydroelectric. In addition to its 93,000 MW of hydroelectric potential, Columbia has estimated coal reserves of 16.5 billion metric tons and $120 \mathrm{bcm}$ of natural gas reserves.

Market Assessment: By most accounts, the electric power sector in Columbia is in critical need of private-sector involvement. Investments in new generation capacity have dropped steadily during the past ten years, creating a near-term capacity shortfall of up to $1000 \mathrm{MW}$. As a result, the government issued an emergency decree removing all restrictions on ownership of private power plants, once a project is approved by the Ministry of Mines and Energy. Several large utility power projects are already underway, including the $340 \mathrm{MW}$ Urra hydroelectric plant in Cordova province. To coordinate financing of electric sector investment, Columbia created Financiera Electrica Nacional (FEN) to mobilize domestic savings and conduct foreign credit operations.

\subsubsection{Panama}

A 1992 government committee recommended that several state-run enterprises, including the Instituto de Recursos Hidraulicos y Electrificacion (IRHE) - the state-owned electric utility - to be privatized and that all new generating plants in Panama be constructed by the private sector. Except for serving the Canal Zone, IRHE is the sole power supplier with installed capacity of $887 \mathrm{MW}$. IRHE is two thirds hydro - dominated by the $300 \mathrm{MW}$ Edwin Fabrega station on the Chiriqui River ( $3 \times 100 \mathrm{MW})$ - and one-third from older oil-fired steam, gas turbine and diesel plants. The Panama Canal Commission, a U.S. government agency, owns and operate $151 \mathrm{MW}$ of capacity; two hydroelectric plants with a combined rating of $60 \mathrm{MW}$, and the Miraflores station consisting of $55 \mathrm{MW}$ and $36 \mathrm{MW}$ of steam and gas turbines, respectively. Panamanian autoproducers have a total installed capacity estimated at $57 \mathrm{MW}$.

Market Assesoment: Before the Privatization Framework Law, IRHE expected to add another 205 MW of capacity by 1999; most of which would be at the Bahia Las Minas station where IRHE planned 
to add an $80 \mathrm{MW}$ diesel-fueled combined cycle plant, convert two simple cycle gas turbines to combined-cycle units, and rehabilitate $80 \mathrm{MW}$ of steam-turbine capacity. IRHE had also been examining a $150 \mathrm{MW}$ coal-fired station ( $2 \times 75 \mathrm{MW})$, and several other hydroelectric plants. Since Panama has no significant fossil fuel reserves it would require them to be imported; hydroelectric potential is estimated at $6,600 \mathrm{MW}$. To date, private sector investors have not had much interest in Panama, despite its tax exemptions, no restrictions on repatriation of profits and use of the U.S. dollar as currency.

\subsubsection{Chile}

The topography of Chile makes provision of electric power difficult: it is $4,345 \mathrm{~km}$ long and $170 \mathrm{~km}$ wide; the bulk of the population, industry and arable land are in the central valley between the Andes Mountains in the east and the Pacific coastal mountains to the west. Today, Chileans get $90 \%$ of their electricity from three large utilities: the investor-owned Empresa nactinal de Electricidad S.A. (Endesa) and Compania Chilena de Generacion Electrica S.A. (Chilgener), and the state-owned Empressa Electric Colbun-Machicura (Colbun). The state also owns Empresa Electrica del Norte Grande (Edelnor), the power generator and distributor in the fast-growing nothern mining region. Together, Endesa, Chilgener and Colbun have a total installed capacity of 3,200 MW; autoproducers and regional utilities have another 1,200 MW. Nationwide, hydroelectric plants (mostly owned by Endesa) account for 2,800 MW (64\%), steam-electric 1,000 MW, oil-fired gas turbines $425 \mathrm{MW}$, with diesels generators the remainder.

Virtually all of the utility capacity feeds the Central Interconnected Systesm (SIC), which comprises more than $7,500 \mathrm{~km}$ of transmission lines. Edelnor has another grid serving the autoproducers in the northern region. In the far north - Norte Grande - a separate grid known as the Sistema Interconectade del Northe Grande (SING) is dominated by independent producers. The southern zone comprises several isolated systems with an installed capacity of $46 \mathrm{MW}$.

The larger Chilean generators belong to Centro de Despacho Economico de Carda (CDEC), which is responsible for determining the sale prices of electrical energy among the generating companies. Sale prices are regulated by a marginal tariff system established in 1982; sale prices charged to distributors correspond to so-called "node prices" determined by another government authority, Comision Nacional de Energia (CNE).

Morket Assessment: To meet an expected 5\% annual growth in electrical demand, Chile plans to add approximately $1,500 \mathrm{MW}-55 \%$ thermal and $45 \%$ hydraulic. Chile currently imports low sulfur coal, to supply its thermal plants, which are typically sited along the coast. It also imports oil and natural gas from Argentina, since most of its own natural-gas reserves (119 bcm) are located in the far south. New pipelines to transport gas are under development to fuel a series of gas-fired combined cycle power plants.

CNE is also interested in acquiring clean coal technologies to intensify development of its 4,600 million metric tons of coal reserves. However, higher-than-expected recovery coal costs and high sulfur content in the Coronel-Lota-Concepcion region caused new mining operations to be closed. At the same time, new deposits of subbituminous coal have been discovered along the Straits of Magellan.

Although all fossil fuels will be used in the future, Chile is very interested in exploiting its $26,000 \mathrm{MW}$ of hydroelectric potential. Recently completed projects include: $144 \mathrm{MW}$ Canutillar station (Endesa), $160 \mathrm{MW}$ Alfalfal station (Chilgener) and the $500 \mathrm{MW}$ Pehuenche station (Perhuenche). The biggest ongoing hydroelectric project is a $500 \mathrm{MW}$ station on the Bio-Bio River at Pangue. 
Private power is also expanding in Chile: Chilgener awarded a tum-key contract to build a $130 \mathrm{MW}$ coal-fired unit at Tocopila. The unit, owned by Corporacion Nacional de Cobre de Chile (CODELCO), will provide power to several mines in the vicinity. Also under construction is a 125 MW coal-fired unit in Mejillones near Antofagasta and another $125 \mathrm{MW}$ coal-fired unit at the port of Huasco south of Antofagasta.

\subsubsection{Argentina}

The power sector in Argentina is rapidly becoming privatized; the government is unbundling utilityowned power plants from the associated transmission and distribution facilities. Today, much of the responsibility for operation of larger plants and T\&D operations is in the private sector. However, the federal govemment still retains substantial equity in the privatized companies and plants.

Over the past five years, electricity consumption in Argentina increased at $6.8 \%$ per year, reaching 57 TWh in 1994. Of this, industrial users accounted for 50\%. Installed capacity at year-end 1994 was 15,740 MW: 7,300 MW thermal, 7,435 MW hydroelectric, and 1,005 MW nuclear. Another 1,195 was expected on-line last year.

Before privatization began four public utilities, one binational agency, 19 provincial utilities and several electric cooperatives supplied Argentineans with power. The major entities are (were):

- $\quad$ Agua y energia Electrica (AYEE) was responsible for generation and transmission nationwide and distribution in four provinces. AYEE aslo coordinated the national power pool.

- Servicios Electricos del Gran Buenos Aires (SEGBA) supplied electricity to the capital and surrounding cities.

- Hidroelectrica Norpatagonia (Hidronor) coordinated development of the hydroelectric resources in North Patagonia, as well as owning power plants and transmission lines.

- Comision Nacional de Energia Atomica (CONEA) operates Argentina's two nuclear plants and ancillary nuclear services.

- Comision Technica Mixta del Salto Grande (CTMSG) runs the 1,900 MW Salto Grande hydroelectric project on the border with Uruguay.

- Provincial utilities - which serve all but four provinces - and the cooperatives in 16 mostlyrural provinces also remain publicly held.

Cia Administradora del Mercado Mayorista Electrico SA (Cammesa), the government agency that coordinates operations of the Argentine electric power sector, estimates that electrical demand growth will be about $4.5 \%$ per year for the next several years. In addition, Ente Nacional Regulador de la Electricidad (ENRE) was formed to regulate the country's power privatization process. The Argentine interconnected system, known as Sistema Argention de Interconexion (SADD, covers $90 \%$ of the country; it also interconnects Argentina with Unuguay, Paraguay, Bolivia and Chile.

Morket Assescment: Before privatization was initiated, government utilities planned to invest $\$ 10$ billion in 7,215 MW of new power plants. These plants will probably be completed under their current ownership schemes, but will be confronted with a competitive market for the sale of the electricity generated (3.75-4.4 cents $\mathrm{kWh}$, as established by ENRE). The mega-projects under development include: $2,700 \mathrm{MW}$ Yacyreta plant being built with Paraugay (20 x $155 \mathrm{MW}) ; 1,400 \mathrm{MW}$ Piedra del Aguila ( $4 \times 350 \mathrm{MW}$ ); and a second unit at Atucha nuclear station (745 MW). Another mega-project is the 4,500 Corpus Christi, being developed by Comision Mixta Argentino-Paraguay de Rio Parana, on the Alto Uruguay and Parana Rivers, will produce $20 \mathrm{TWh}$ year for sale to Argentina, Brazil and 
Paraguay. Beyond these hydro projects, development of Argentina's reserves of natural gas, estimated at $560 \mathrm{bcm}$, is expected to promote the development of gas turbines and combined cycle plants.

\subsection{ASSESSMENT OF TECHNOLOGY MARKET POTENTIAL AND BARRIERS}

Based on the power market assessment by country in the preceding sections, the following summarizes the market potential for small-scale fluidized bed combustors and coal-fired diesel generators in the identified developing countries. In general, data on fuels other than coal were not readily available. In addition, proximity of the local load to coal fields/transport systems and identification of communities without grid access and needing power requires a site-specific analysis not included in this screening analysis. Additional market details are provided for those countries rated with "high" potential.

\subsubsection{Africa}

Table 4.6.1 summarizes the power market indicators by country in Africa. It indicates that only a few countries have coal reserves and currently use coal for power generation. Alternatively, 10 countries have large hydroelectric potential, with many countries relying on hydro power for cier $90 \%$ of their generation. While an interconnected grid exists in all countries, the extensiveness of the grid and degree of electrification is low in most African countries. Finally, several countries have explicit programs to increase rural electrification (see Section 4.1 for details).

Table 4.6.2 relates the market potential for FBCs and CFDs in Africa by country, together with the major market barriers. While market potential exists for these technologies, in most countries the potential for FBCs is low, since hydroelectric generation is the primary source of current and future baseload power. Alternatively, CFDs could exploit a niche by displacing oil-fired diesels in both urban and remote areas, particularly where a country has experienced difficulty financing oil purchases (e.g., Tanzania, Zaire) and has instituted a program to explore alternatives. While both Madagascar and Niger have a large number of diesel units, they are rated as "moderate" since they are without indigenous coal resources, and any increased coal consumption would necessitate development of potentially costly coal infrastructure.

Most of the developing countries in Africa have instituted some typelevel of private power and/or privatization program, which introduces opportunities for advanced power technologies, if they can be price-competitive. Until electric tariffs are revised and rate subsidies removed this the market is likely to be distorted against coal-based power systems. Further examination of these markets is necessary before a more precise indication of the market potential for FBCs and CFDs can be provided.

Two countries are rated with "high" market potential: Zimbabwe and Morocco.

Zimbabwe. Through its rural electrification program Zimbabwe hopes to expand grid connection beyond the $20 \%$ level that currently exists. In addition. Zimbabwe is eager to electrify rural households to reduce their use of wood and other biomass fuels. Installation of coal-fired (and/or multi-fuel) fluidized bed boilers and coal-fired diesels on micro-grids would . achieve this goal and reduce the need to string costly transmission lines to remote villages. 
Table 4.6.1

Market Indicators Summary: Africa

\begin{tabular}{|c|c|c|c|c|c|c|c|c|c|c|}
\hline Country & $\begin{array}{c}\text { Coal } \\
\text { Reserves }\end{array}$ & $\begin{array}{c}\text { Power Gen: } \\
\text { Coal }\end{array}$ & $\begin{array}{c}\text { Hydro } \\
\text { Resources }\end{array}$ & $\begin{array}{c}\text { Power Gen: } \\
\text { Hydro }\end{array}$ & $\begin{array}{c}\text { Power Gen: } \\
\text { Diesel }\end{array}$ & $\begin{array}{c}\text { NG } \\
\text { Reserves }\end{array}$ & $\begin{array}{c}\text { Power Gen: } \\
\text { NG }\end{array}$ & $\begin{array}{c}\text { Interconnected } \\
\text { Grid }\end{array}$ & $\begin{array}{l}\text { Demand } \\
\text { Growth }\end{array}$ & $\begin{array}{l}\text { Electricity } \\
\text { Transfer }\end{array}$ \\
\hline Mozambique & $\checkmark$ & $\sqrt{ }$ & large & $\checkmark$ & $\checkmark$ & - & - & partial & moderate & expont \\
\hline Tanzania & $\checkmark$ & $\checkmark$ & lange & $\checkmark$ & $\checkmark$ & large & $-a^{a}$ & partial & high & import \\
\hline Malawi & - & - & small & $\checkmark$ & $\checkmark$ & - & -- & partial & moderate & -- \\
\hline Burundi & $\checkmark$ & $\cdots$ & large & $\checkmark$ & -- & - & -- & partial & low & import \\
\hline Zaire & large & -- & large & $\checkmark$ & $\checkmark$ & large & - & partial & low & export \\
\hline Madagascar & - & - & large & $\checkmark$ & $\checkmark$ & -- & -- & partial & low & - \\
\hline Nigeria & $\checkmark$ & - & moderate & $\checkmark$ & $\checkmark$ & lange & $--{ }^{a}$ & partial & low & export \\
\hline Niger & $\checkmark$ & -- & - & - & $\checkmark$ & - & -. & partial & low & import \\
\hline Kenya & -- & - & lange & $\checkmark$ & $\checkmark$ & - & - & partial & moderate & import \\
\hline Ghana & -- & -. & large & $\checkmark$ & $\checkmark$ & - & -- & partial & high & export \\
\hline Zambia & $\checkmark$ & - & large & $\checkmark$ & $\checkmark$ & $\cdots$ & -- & partial & low & export \\
\hline Mauritania & -- & - & small & $\checkmark$ & $\checkmark$ & - & -- & partial & low & import \\
\hline Egypt & - & $\checkmark$ & low & $\checkmark$ & $\checkmark$ & $\checkmark$ & $\checkmark$ & moderate & moderate & - \\
\hline Zimbabwe & $\checkmark$ & $\checkmark$ & moderate & $\checkmark$ & $\checkmark$ & - & - & moderate & moderate & import \\
\hline Morocco & $\checkmark$ & $\checkmark$ & low & $\checkmark$ & $\checkmark$ & - & $\checkmark$ & partial & high & import \\
\hline Cameroon & - & -- & large & $\checkmark$ & $\checkmark$ & $\checkmark$ & - & moderate & moderate & - \\
\hline Tunisia & - & $\checkmark$ & low & $\checkmark$ & $\checkmark$ & - & $\checkmark$ & moderate & low & -- \\
\hline Algeria & -- & - & low & $\checkmark$ & $\checkmark$ & large & $\checkmark$ & moderate & moderate & export \\
\hline Maurilius & - & -- & low & $\checkmark$ & $\checkmark$ & $=$ & - & partial & low & - \\
\hline
\end{tabular}

under development 


\section{TABLE 4.6.2}

Market Potential Rating: Africa

\begin{tabular}{|l|c|c|l||}
\hline \multicolumn{1}{|c|}{ Country } & $\begin{array}{c}\text { FBC Market } \\
\text { Potential }\end{array}$ & $\begin{array}{c}\text { Coal-Fired Diesel } \\
\text { Market Potential }\end{array}$ & \\
\hline Mozambique & low & moderate (11) & hydroelectric \\
Tanzania & low & moderate & Major Barriers \\
Malawi & low & hydroelectric, natural gas \\
Burundi & low & low & hydroelectric \\
Zaire & low & low & hydroelectric \\
hadagascar & low & moderate (56) & hydroelectric, no indigenous coal, underutilized capacily \\
Nigeria & low & low & hydroelectric, natural gas \\
Niger & low & moderate (54) & imported-power, no indigenous coal \\
Kenya & low & low & hydroelectric, investment, electricily tariffs \\
Ghana & low & low & hydroelectric, natural gas \\
Zambia & low & low (16) & hydroelectric \\
Mauritania & low & low & hydroelectric, imported power \\
Egypt & moderate & moderate & mechanisms for private powers, elimination of \\
& & high & hydroelectric \\
Zimbabwe & high & hydectric rates \\
Morocco & high & high & natural gas from Algeria \\
Cameroon & low & low & natural gas, hydroelectric \\
Tunisia & low & moderate & \\
Algeria & low & low & natural gas, no indigenous coal \\
Mauritius & low & low & no indigenous coal; bagasse and hydroelectric \\
\hline
\end{tabular}

numbers in parentheses ( ) indicate number of known diesel units. 
Morocco. While Morocco does not have significant coal reserves, it currently produces and consumes coal for power generation. With a projected growth in demand of $7 \%$, a program to increase rural electrification beyond the current $25 \%$ leveh, and U.S. private power developers already active in Morocco, the opportunity exists for U.S. distributed coal-fired power systems to serve the Moroccan power market. In addition, Morocco hopes to reduce its reliance on imported oil, which currently accounts for $80-90 \%$ of its commercial energy requirements, by obtaining royalty gas for transit rights associated with Algerian natural gas shipments to Spain via the Maghreb-Europe pipeline; but this requires a construction of a complete gas infrastructure.

\subsubsection{Asia}

Table 4.6.3 presents the markets indicators for Asia. Most of the developing countries in Asia rely extensively on hydroelectricity for baseload power: Indonesia, India and China have equal and growing shares of coal-based power to serve baseload demand. Since many of these countries are projected to have large growth rates in demand for the foreseeable future - even with there extensive hydroelectric capacity and resource potential - there remains many opportunities for small, coal-based technologies. These technologies would complement the rural electricification programs underway in many of these countries (see Section 4.2).

A summary of the market potential for these small, coal-fired power technologies is contained in Table 4.6.4. Six countries (India, China, Pakistan, Indonesia, Vietnam, Philippines and Thailand) have high potential for FBC adoption; the same countries are categorized as having a high potential for coal-fired diesels. The major barrier, when not hydroelectric potential, is project financing. Many (most) of these developing countries do not have an intemal means to generate capital (i.e., savings or pension funds), so they must rely on outside investors for equity and debt capital. This impacts all power projects; however, it may have a lesser impact on small-scale projects since they demand less capital and often have less commercial/technological/political risk than larger projects. Another development that might facilitate investment is private power laws and privatization. Many of these Asian countries have created (or are in the process of creating) an environment to entice private power developers to construct the required generating capacity.

Six countries are rated with a "high" market potential: India, China, Pakistan, Indonesia, Vietnam, Philippines and Thailand.

India. While India has many large-scale coal and natural gas power projects under development, the T\&D system still does not serve many remote villages and experiences large variations in line voltage and substantial losses thus impacting deliverability, reliability and rural electrification. To satisfy the rapidly expanding power needs of the Indian states, micro-grids supplied by coal-fired FBCs and coal-fired diesels would achieve the electrification goals and reduce demands on the overburdened national grid.

China. China is projected to need $400 \mathrm{GW}$ of new generating capacity by 2020 . Moreover, China has hundreds of remote villages that - like the explosion of cellular telephones usage are probably best served by advanced concepts such as micro-grids powered with small, coalfired generators (FBCs and CFDs) rather than stringing new transmission lines. Since many of these villages are co-located in those areas with coal reserves, minimal coal transportation is likely to be required. A geographic mapping of the coal reserves, remote population load 


\begin{tabular}{|c|c|c|c|c|c|c|c|c|c|c|}
\hline \multicolumn{11}{|c|}{$\begin{array}{c}\text { TABLE } 4.6 .3 \\
\text { Market Indicators Summary: Asia }\end{array}$} \\
\hline Country & $\begin{array}{c}\text { Coal } \\
\text { Resources }\end{array}$ & $\begin{array}{c}\text { Power Gen: } \\
\text { Coal }\end{array}$ & $\begin{array}{c}\text { Hydro } \\
\text { Resources }\end{array}$ & $\begin{array}{c}\text { Power Gen: } \\
\text { Hydro }\end{array}$ & $\begin{array}{c}\text { Power Gen: } \\
\text { Diesel }\end{array}$ & $\begin{array}{c}\text { NG } \\
\text { Reserves }\end{array}$ & $\begin{array}{c}\text { Power Gen: } \\
\text { NG }\end{array}$ & $\begin{array}{c}\text { Interconnected } \\
\text { Grid }\end{array}$ & $\begin{array}{l}\text { Demand } \\
\text { Growth }\end{array}$ & $\begin{array}{l}\text { Electricity } \\
\text { Transfer }\end{array}$ \\
\hline Nepal & - & - & lange & 1 & $\checkmark$ & - & $\cdots$ & partial & low & import \\
\hline $\begin{array}{l}\text { Laos } \\
\text { Bangladesh }\end{array}$ & $\overline{-}$ & - & $\begin{array}{c}\text { large } \\
\text { moderate }\end{array}$ & 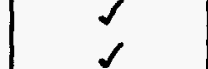 & 8 & $\bar{s}$ & $\bar{s}$ & $\begin{array}{l}\text { partial } \\
\text { partial }\end{array}$ & low & export \\
\hline $\begin{array}{l}\text { India } \\
\text { Incsil }\end{array}$ & large & 2 & moderate & $\checkmark$ & $\checkmark$ & $s$ & 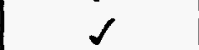 & moderate & $\begin{array}{l}\text { high } \\
\text { high }\end{array}$ & - \\
\hline China & lange & 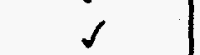 & larg & 4 & $\checkmark$ & large & $s$ & partial & high & -- \\
\hline stan & $\checkmark$ & $\checkmark$ & & $\checkmark$ & 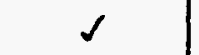 & large & $s$ & artial & high & -- \\
\hline anka & - & -. & Ian & 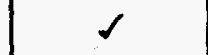 & $s$ & -- & -- & partial & low & - \\
\hline In & large & $\checkmark$ & Iar: & $\checkmark$ & $\checkmark$ & $\checkmark$ & $\checkmark$ & partial & high & - \\
\hline Myanmar & 5 & $s$ & lange & $s$ & $s$ & $s$ & -- & partial & moderate & export \\
\hline Vietnam & large & $\checkmark$ & large & $\checkmark$ & $s$ & lange & $\checkmark$ & partial & high & export \\
\hline Philippines & $\checkmark$ & $\checkmark$ & $\checkmark$ & $\checkmark$ & $s$ & small & $\checkmark$ & partial & moderate & - \\
\hline New Guinea & -- & - & $\checkmark$ & $\checkmark$ & $\checkmark$ & - & - & partial & low & -- \\
\hline & $\checkmark$ & $\checkmark$ & moderale & $d$ & $\checkmark$ & large & $\checkmark$ & & high & import \\
\hline Malaysia & 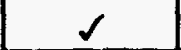 & $\checkmark$ & & 6 & 6 & lange & $\checkmark$ & partial & high & export \\
\hline
\end{tabular}




\begin{tabular}{|c|c|c|c|}
\hline \multicolumn{4}{|r|}{$\begin{array}{l}\text { TABLE 4.6.4 } \\
\text { Market Potential: Asia }\end{array}$} \\
\hline Country & $\begin{array}{l}\text { FBC Market } \\
\text { Potential }\end{array}$ & $\begin{array}{l}\text { Coal-Fired Diesel } \\
\text { Market Potential }\end{array}$ & Major Bamiers \\
\hline $\begin{array}{l}\text { Nepal } \\
\text { Laos } \\
\text { Bangladesh } \\
\text { India } \\
\text { China } \\
\text { Pakistan } \\
\text { Sri Lanka } \\
\text { Indonesia } \\
\text { Myanmar } \\
\text { Vietnam } \\
\text { Philippines } \\
\text { New Guinea } \\
\text { Thailand } \\
\text { Malaysia }\end{array}$ & $\begin{array}{c}\text { low } \\
\text { low } \\
\text { moderate } \\
\text { high } \\
\text { high } \\
\text { high } \\
\text { moderate } \\
\text { high } \\
\text { moderate } \\
\text { high } \\
\text { high } \\
\text { low } \\
\text { high } \\
\text { moderate }\end{array}$ & $\begin{array}{l}\text { moderate } \\
\text { low } \\
\text { moderate } \\
\text { high } \\
\text { high } \\
\text { high } \\
\text { moderate } \\
\text { high } \\
\text { moderate } \\
\text { high } \\
\text { high } \\
\text { low } \\
\text { high } \\
\text { moderate }\end{array}$ & $\begin{array}{l}\text { hydroelectric } \\
\text { hydroelectric } \\
\text { natural gas; cash flow; refinery by products } \\
\text { continuity of project support; LNG/NG combined cycle } \\
\text { project funding } \\
\text { project funding; tariff structure } \\
\text { hydroelectric } \\
\text { project funding; tariff structure } \\
\text { hydroelectric } \\
\text { hydroelectric; project funding } \\
\text { coal not located near load centers; project funding; altemative fuels } \\
\text { hydroelectric; small resource base } \\
\text { natural gas } \\
\text { natural gas }\end{array}$ \\
\hline
\end{tabular}


centers, and current power generation sources is needed to assess the viability of micro-grids, from which an economic assessment of the technology options could be then conducted.

Pakistan. Pakistan estimates that it needs $14,500 \mathrm{MW}$ of new capacity by 2000 and would prefer to have private power developers construct most of these plants. In addition, 288 million tons of coal and lignite reserves exist. Electricity is available to $40 \%$ of the population; most nural areas are not electrified. Since Pakistan is experienced with private power, microgrid opportunities by U.S. vendors of FBC and CFD technologies could be more readily developed.

Indonesia. Due to the large demand for power on Java, most recently completed and planned projects have been large in scale (greater than $1000 \mathrm{MW}$ ). However, there are approximately 2,500 remote villages not yet connected to the grid; moreover, many villages are on outlying islands currently served by diesel generators ( $20 \%$ of capacity). Indonesia is exploring options to reduce domestic consumption of oil and natural gas in order for these fuels to be used to generate governmental revenue as export commodities. Thus, with its extensive coal resource base ( 32 billion tons) there are likely to be opportunities for small, coal-fired systems to serve as power sources for micro-grids within some of these remote villages currently served by diesel generators or not yet electrified.

Vietnam. Electricity demand in Vietnam is expected to outpace the economy, with growth of $12-14 \%$ per year. While it has substantial hydroelectric capacity ( $75 \%$ of current generation), with potential for $15,000 \mathrm{MW}$ of additional capability, Vietnam also has 2 billion tons of coal. Since Vietnam cannot make all of the necessary power sector investments, private power project opportunities exist to serve both the urban and rural areas with whatever generating technology is most appropriate and cost-effective. One option is for small-scale FBCs and CFDs to serve the domestic market, while hydroelectric capacity is used to generate export revenues through sales to Laos and China (southem provinces).

Philippines. The Philippines has 65 million people spread over 7,100 islands, with 120 rural electric cooperatives. Like many other Asian countries, rural electrification is a means to stem the urbanization tide. In the Philippines, rural cooperatives have achieved an electrification level of $60 \%$, with a goal of $77 \%$ by 2000 . This goal, coupled with the goal to reduce the share of oil-fired generation (currently $50 \%$ ) to improve balance-of-payments, presents market opportunities for small-scale, remotely sited coal-fired power systems. A more in-depth analysis of the market is needed, however, before an estimate of the potential market can be determined.

Thailand. Thailand is projected to add more than $25 \mathrm{GW}$ by 2011 ; it announced in early 1995 that no further hydroelectric capacity will be permitted due to potential damage to surrounding environmental and ecological systems. As a result, at present, natural gas is the fuel of choice; however, Thailand has considerable coal reserves and with advanced power systems these reserves could be used to produce electricity with negligible environmental impact. This is particularly true if small-scale FBC and CFD systems are used as power sources for microgrids in remote villages. 


\subsubsection{Central/Eastern Europe}

Table 4.6.5 relates that the three developing countries considered in this study (Romania Poland and Bulgaria) rely on all fuel sources for power generation. While all three countries have a "moderate" interconnected grid, there remains opportunities for small-scale power systems due to inefficiencies in the current grid and isolated pockets of demand growth. As a result there is a "moderate" to "high" market potential for FBC and CFD applications in these markets (Table 4.6.6). The primary competition for deployment of these technologies is with the excess (although inefficient) capacity that currently exists in each country. The available capital for power sector investments will be competed between refurbishment and new plant. In Romania and Bulgaria the other competing issue is whether to continue operation of their nuclear plants. Additional investigation of these competing demands is necessary in order to better define (and quantify) the market potential for FBC and CFD in remote applications.

Two countries are rated with a "high" market potential: Poland and Bulgaria.

Poland. More than $95 \%$ of the electricity generated in Poland is coal-based. An additional $5,100 \mathrm{MW}$ of new capacity is projected by 2000 . Due to the need for new capacity, coupled with the replacement/refurbishment and environmental retrofit (achieving 70\% SO2 control) of $3,000 \mathrm{MW}$ of existing capacity, there exists an opportunity for small-scale, advanced coal-fired power systems to serve the incremental demand growth cost-effectively and in-excess of current environmental requirements. With emissions trading being considered, there would be economic value to this over-control, which could - if necessary - compensate for any higher technology capital cost of the advanced systems.

Bulgaria. Bulgaria hopes to build six new coal- and lignite-fired power plants totaling 1,500 MW to replace obsolete equipment. In addition, Bulgaria plans to install FGD units on all future coallignite plants and convert several $50 \mathrm{MW}$ coal-fired boilers to FBCs. These plans, coupled with the possible need to replace the two V-230 nuclear reactors, create an opportunity for small-scale FBCs and CFDs to serve current/future load requirements.

\subsubsection{Middle East/Near East}

Turkey is the only developed country in this region considered, and it was rated with a "high" market potential. While Turkey has a large hydro resource base and a moderate interconnected grid, it is projected to experience a high rate of growth (8\%/annum) in demand (Table 4.6.7); this would require installed capacity to expand from 18,714 in 1992 to $33,400 \mathrm{MW}$ by 2000 and 58,400 by 2010 . By 2010 , some sources project that indigenous oil/gas supplies in Turkey will be depleted, forcing Turkey to rely increasingly on its lignite (and hydroelectric) resources. These facts, coupled with the topography and distributed nature of the population and coal resource base, presents numerous opportunities for small-scale FBC and CFD units (Table 4.6.8). 


\begin{tabular}{|c|c|c|c|c|c|c|c|c|c|c|}
\hline \multicolumn{11}{|c|}{$\begin{array}{c}\text { Table } 4.6 .5 \\
\text { Market Indicators Summary: Central/Eastern Europe }\end{array}$} \\
\hline Country & $\begin{array}{c}\text { Coal } \\
\text { Reserves }\end{array}$ & $\begin{array}{c}\text { Power Gen: } \\
\text { Coal }\end{array}$ & $\begin{array}{c}\text { Hydro } \\
\text { Resources }\end{array}$ & $\begin{array}{c}\text { Power Gen: } \\
\text { Hydro }\end{array}$ & $\begin{array}{c}\text { Power Gen: } \\
\text { Diesel }\end{array}$ & \begin{tabular}{c|} 
NG \\
Reserves \\
\end{tabular} & $\begin{array}{c}\text { Power Gen: } \\
\text { NG }\end{array}$ & \begin{tabular}{|c|}
$\begin{array}{c}\text { Interconnected } \\
\text { Grid }\end{array}$ \\
\end{tabular} & $\begin{array}{l}\text { Demand } \\
\text { Growth }\end{array}$ & $\begin{array}{l}\text { Electricity } \\
\text { Transfer }\end{array}$ \\
\hline $\begin{array}{l}\text { Romania } \\
\text { Poland } \\
\text { Bulgaria }\end{array}$ & $\begin{array}{c}\checkmark \\
\text { large } \\
\checkmark\end{array}$ & $\begin{array}{l}2 \\
2 \\
2\end{array}$ & $\begin{array}{l}2 \\
2 \\
2\end{array}$ & $\begin{array}{l}2 \\
\checkmark \\
\checkmark\end{array}$ & $\begin{array}{c}2 \\
2 \\
2\end{array}$ & $\begin{array}{l}-- \\
- \\
-\end{array}$ & $\begin{array}{l}1 \\
1 \\
2\end{array}$ & $\begin{array}{l}\text { moderate } \\
\text { moderate } \\
\text { moderate }\end{array}$ & $\begin{array}{l}\text { low } \\
\text { low } \\
\text { low }\end{array}$ & $\begin{array}{c}- \\
\text { export } \\
\text { import }\end{array}$ \\
\hline
\end{tabular}


TABLE 4.6.6

Market Potential Rating: Central/Eastern Europe

\begin{tabular}{||l|c|c|c|}
\hline Country & $\begin{array}{c}\text { FBC Market } \\
\text { Potential }\end{array}$ & $\begin{array}{c}\text { Coal-Fired Diesel } \\
\text { Market Potential }\end{array}$ & \multicolumn{1}{|c|}{ Major Barriers } \\
\hline Romania & moderate & low & $\begin{array}{l}\text { nuclear power; excess capacity; need to refurbish } \\
\text { existing capacity } \\
\text { Poland }\end{array}$ \\
Bulgaria & high & moderate & $\begin{array}{l}\text { competition for funds required to refurbish } \\
\text { existing capacity and install environmental controls } \\
\text { uncertainty in operation/investment requirements } \\
\text { of nuclear power plants; project funding }\end{array}$ \\
\hline
\end{tabular}


Table 4.6.7

Market Indicators Summary: Middle East/Near East

\begin{tabular}{|c|c|c|c|c|c|c|c|c|c|c|}
\hline Country & $\begin{array}{c}\text { Coal } \\
\text { Reserves }\end{array}$ & $\begin{array}{c}\text { Power Gen: } \\
\text { Coal }\end{array}$ & $\begin{array}{c}\text { Hydro } \\
\text { Resources }\end{array}$ & $\begin{array}{c}\text { Power Gen: } \\
\text { Hydro }\end{array}$ & $\begin{array}{c}\text { Power Gen: } \\
\text { Diesel }\end{array}$ & $\begin{array}{c}\text { NG } \\
\text { Reserves }\end{array}$ & $\begin{array}{c}\text { Power Gen: } \\
\text { NG }\end{array}$ & $\begin{array}{c}\text { Interconnected } \\
\text { Grid }\end{array}$ & $\begin{array}{c}\text { Demand } \\
\text { Growth }\end{array}$ & $\begin{array}{c}\text { Electricity } \\
\text { Transfer }\end{array}$ \\
\hline Turkey & $\checkmark$ & $\checkmark$ & large & $\checkmark$ & $\checkmark$ & $\checkmark$ & $\checkmark$ & moderate & high & expont \\
\hline
\end{tabular}




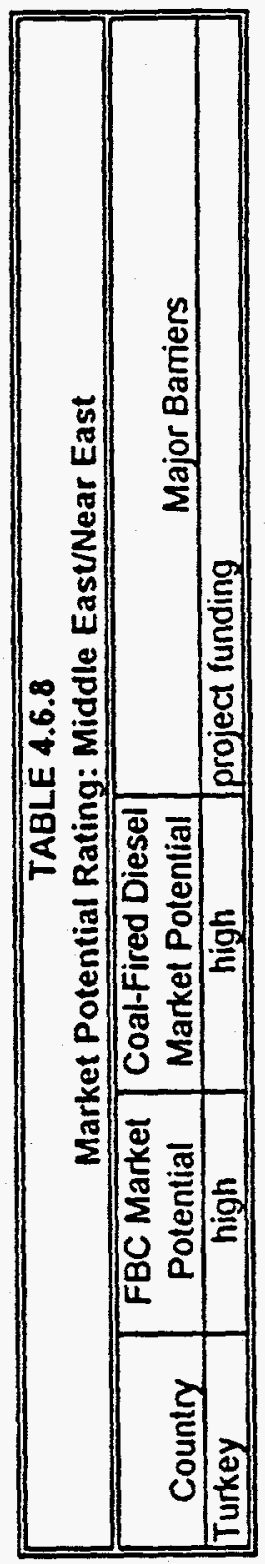




\subsubsection{CentralSouth America}

Table 4.6.9 summarizes the market indicators for Central/South America. Those countries classified as "developing" in Central/South America have either a moderate or large hydroelectric resource base. They also have only a partial interconnected grid; this is attributable to their topography and current population load center distribution. In most cases, these countries are projected to experience moderate growth in electricity demand.

Since these countries have a need for small power systems to meet current and future power needs, they have either a moderatehigh potential for both FBC and CFD systems (Table 4.6.10). The major barrier to their adoption appears to be competition with hydroelectric or natural gas capacity; however, many of these countries wish to diversify their fuel base in order to increase reliability and avoid the power shortages experienced during the past several years. This policy, coupled with the privatization and private power initiatives in many (most) of these countries, permits the introduction of advanced small-scale FBC and CFD technologies.

Three countries were rated with a "high" market potential: Peru, Columbia and Chile.

Peru. Almost $50 \%$ of Peru's thermal capacity ( $310 \mathrm{MW}$ ) is older diesel machines. In addition, ElectroPeru and ElectroLima have not added a new hydroelectric plant $(2,000 \mathrm{MW})$ in 20 years. If coal can be imported, then coal-fired diesels have an opportunity to replace some of this older thermal capacity, and potentially serve the projected 1,200 MW of new load over the next 10 years. The major competitor for coal is natural gas; but it requires the construction of a 500-mile gas pipeline to link the new gas field at Camisea with the coastal load centers.

Columbia. There is a $1000 \mathrm{MW}$ capacity shortfall at present, with a projected need for 2,000$3,000 \mathrm{MW}$ of additional capacity before the year 2000 . While $60 \%$ of this capacity is expected to be hydroelectric, construction of these facilities may not be in-time to serve the projected load growth, thereby creating a protracted capacity shortfall. Small-scale FBCs and CFDs could be constructed rapidly by U.S. vendors, draw on Columbia's extensive coal reserves ( 16.5 billion metric tons), and be responsive to the emergency degree issued by the Ministry of Mines and Energy removing all restrictions on ownership of private power plants, once approved by the Ministry.

Chile. Annual load growth is expected to be $5 \%$, corresponding to the addition of approximately $1,500 \mathrm{MW}$ of new capacity (55\% thermal, $45 \%$ hydraulic). Given the topography of Chile $(4,345 \mathrm{~km}$ long, $170 \mathrm{~km}$ wide), small-scale, coal-fired power systems would best serve local load centers and maintain overall system reliability; these technologies could also readily provide the generation for micro-grids in remotely-sited villages in the mountainous areas of Chile. These market characteristics coupled with the promotion of private power development and Chile's interest in clean coal technologies, enhances the market potential for FBCs and CFDs. 


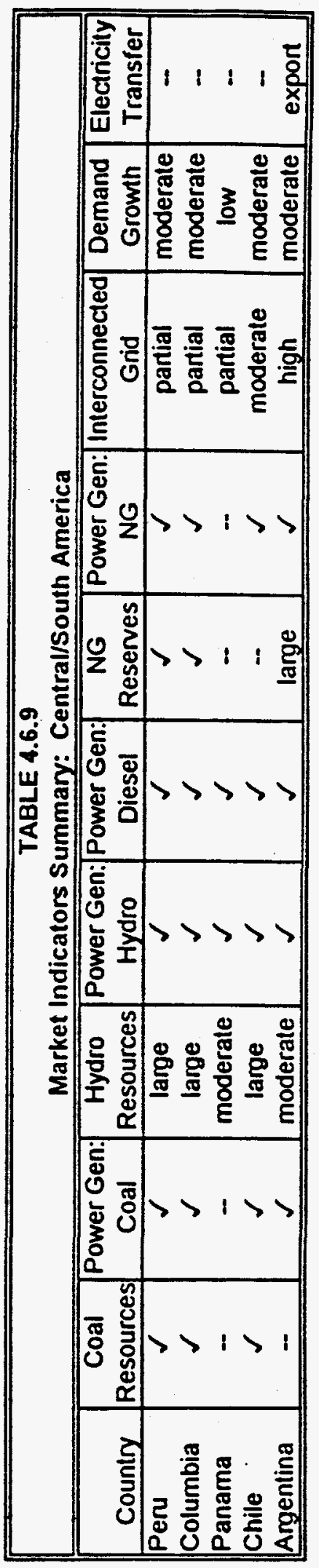


TABLE 4.6.10

Market Potential Rating: Central/South America

\begin{tabular}{|c|c|c|c|}
\hline Country & $\begin{array}{l}\text { FBC Market } \\
\text { Potential }\end{array}$ & $\begin{array}{l}\text { Coal-Fired Diesel } \\
\text { Market Potential } \\
\end{array}$ & Major Barriers \\
\hline $\begin{array}{l}\text { Peru } \\
\text { Columbia } \\
\text { Panama }\end{array}$ & $\begin{array}{l}\text { moderate } \\
\text { high } \\
\text { moderate }\end{array}$ & $\begin{array}{l}\text { high } \\
\text { high } \\
\text { moderate }\end{array}$ & $\begin{array}{l}\text { hydroelectric, natural gas; low tariffs } \\
\text { project financing } \\
\text { no indigenous fossil fuels; lack of interest by } \\
\text { private power developers }\end{array}$ \\
\hline $\begin{array}{l}\text { Chile } \\
\text { Argentina }\end{array}$ & $\begin{array}{c}\text { high } \\
\text { moderate }\end{array}$ & $\begin{array}{c}\text { high } \\
\text { moderate }\end{array}$ & $\begin{array}{l}\text { hydroelectric, natural gas } \\
\text { hydroelectric, natural gas }\end{array}$ \\
\hline
\end{tabular}




\section{References}

American Embassy- New Delhi, 1993, Petroleum and Natural Gas in Inctia.

Coal Industry Advisory Board, 1993, Global Coalbed Methane Recovery and Use: Current Practices and Prospects for Expansion (September).

Coalbed Methane Clearinghouse, 1995, China Coalbed Methane (May).

India Ministry of Environment and Forests, 1992, Scientific Report Number 4, Global Change Greenhouse Gas Emission In India.

Industrial \& Petrochemical Consultants (Pty) Ltd., 1991, Coal-Bed Methane Resource Development (May).

Kuchgessner, et al, 1995, Estimate of Global Methane Emissions From Coal Mines, U.S. Environmental Protection Agency.

Lawrence Berkeley National Laboratory, 1993, China Energy Databook, LBL-32822.Rev.3.UC-350.

Microsoft, Encarta'95, 1995.

Surridge \& Grobbelaar, 1994, Energy In South Africa: The Gas Connection, (September 22).

The Nystrom Desk Atlas, 1994.

U.S. Department of Energy, 1994a, Country Factbook, Energy Information Administration Report (December).

U.S. Department of Energy, 1994b, Presidential Mission on Energy and Trade to India (July).

U.S. Department of Energy, 1995, International Energy Anmual 1993, Energy Information Administration Report DOEEIA-0219(93) (May).

U.S. Environmental Protection Agency, 1991, Assessment of the Potential for Economic Development and Utilization of Coalbed Methane in Poland (August).

U.S. Environmental Protection Agency, 1993, Report to Congress, Options for Rectucing Methane Emissions Internationally; Volume II: Intermational Opportunities for Rechucing Methane Emissions (October).

U.S. Environmental Protection Agency, 1995a, Reducing Methane Emissions from Coal Mines in Russia: A Handbook for Expanding Coalbed Methane Recovery and Use in the Kumetsk Coal Basin (September). 


\section{References (continued)}

U.S. Environmental Protection Agency, 1995b, Reducing Methane Emissions from Coal Mines in China: The Potential for Coalbed Methane Development (October).

U.S. Environmental Protection Agency, 1995c, Rectucing Methane Emissions from Coal Mines in Poland: A Handbook for Expanding Coalbed Methane Recovery and Utilization in the Upper Silesion Coal Basin (April).

World Book, 1988, The World Book Encyclopedia, 1988 Edition. 
ATTACHMENT 1

THE ALASKAN INITLATTVE 


\section{THE ALASKAN INITIATTVE}

\section{GOAL OF THE ALASKAN INITIATTVE}

The goal of the Alaskan Initiative is to demonstrate emerging energy systems to displace imported diesel fuel in rural villages in Alaska. The energy systems would provide electricity and, in some cases, heat or steam for heating buildings. In addition, they may co-fire municipal waste. The fuel would be locally produced coal or natural gas including coal-bed methane. The U.S. Department of Energy (DOE), Morgantown Energy Technology Center (METC), and the Energy \& Environmental Research Center (EERC) have been working closely with several Alaskan native corporations, Alaska government officials, and U.S. vendors of small power generation equipment to initiate this activity.

\section{BENEFITS OF THE ALASKAN INITIATIVE}

1. Make Affordable Emerging Energy Systems Available to the Over 120 Remote Villages in Alaska

Energy costs in remote villages are currently very high. Most villages have stand-alone systems to produce electricity using oil-fired diesel generators. Residents in the village also use oil for heating their homes and for cooling. The severe climate makes it necessary to barge or fly an entire year's supply of oil into each village during the summer season. Because of high transportation costs, electricity and fuel costs are 4 to 12 times higher than in the lower 48 states. The state of Alaska subsidizes this high cost of electricity in rural villages. However, the revenue source for this subsidy (a tax on crude oil shipments through the Alaskan pipeline) is shrinking, which may lead to the elimination of the subsidy. Thus both the native corporations and the state government want to identify lower-cost energy systems for both electricity and heat production.

2. Demonstrate Low-Emission Systems that Can Contribute Toward Integrated Solutions of Current Environmental Problems

Many want the Alaskan environment to remain pristine and, therefore, want energy systems with very low emissions. Systems with lower emissions than those of uncontrolled diesel generators are desired.

Alaskans also want energy systems that can help alleviate current environmental problems with leaking oil tanks and with municipal solid waste. Villages store a 1-to 1.5-year supply of oil in above-ground, bulk storage facilities that were installed by the Bureau of Indian Affairs in the 1940 s and 1950s. Leaking tanks in these facilities are creating major environmental and safety problems. Replacing the tanks will cost $\$ 200$ to $\$ 400$ million, exclusive of the cost to remediate the current ground and water contamination. Fewer tanks will need to be replaced if emerging power systems fueled by natural gas or coal were to be installed under the Alaskan Initiative. The risk of future ground or surface water contamination would also be reduced.

Disposal of municipal solid waste is an ongoing problem in Alaska. Harsh 
weather conditions and permafrost preclude the use of many of the disposal options common to the lower 48 states. Thus energy technologies that have the flexibility to codispose municipal waste are desirable.

\section{Create Local Jobs in Alaskan Villages}

Undeveloped coal and natural gas resources underlay much of Alaska. Although Alaska has only one operating coal mine (the Usibelli mine in central Alaska), it has vast untapped resources of very low-sulfur coal throughout the state. Many rural villages are close to known, shallow coal deposits. Most of Alaska's known natural gas resources are located on the North Slope. In the interior region, the geology indicates there is a good potential for natural gas, although this has not been confirmed by exploratory drilling. Because of the vast amount of coal throughout the state, the potential for coal-bed methane is also good. Thus many Alaskan villages have coal or gas resources located nearby. Many of these resources are near the surface and, therefore, have the potential to cost-effectively supply the relatively small amounts of fuel needed for a rural village power generation project.

Using coal or natural gas that is locally produced creates local jobs. The funds to buy fuel stay in the region instead of being siphoned off to out-of-state suppliers of diesel fuel.

Transportation cost is the major contributor to the high cost of diesel oil. Because of lower transportation costs, locally produced fuels should be lower in cost, which, in turn, would reduce the cost of electricity and heat for local residents. In Alaska, the legal issues surrounding energy resource development are relatively simple since the native corporations typically own the energy resources on their land. (This is unique to Alaska; in the lower 48, Native Americans typically do not have rights to the energy resources on their land.)

4. Demonstrate the Capability and Versatility of Coal-Fired or Natural Gas-Fired Emerging Energy Systems

Over the past several years, DOE METC has supported Research \& Development (R\&D) on small-scale power generation technologies. Several of these technologies are in the early commercialization stage and have the characteristics desired by remote villages in Alaska, i.e.,-costeffectiveness, low emissions, reliability, standardized design, and the ability to be factory fabricated. Technology options include:

- Phosphoric acid fuel cells (PAFCs). PAFCs in the $200-\mathrm{kW}$ size are ready for commercial deployment. They can operate on pipeline or lower-quality natural gas and are sold as prepackaged units. In addition to electricity, PAFCs provide hot water for heating and other uses. They are among the cleanest and most efficient energy technologies.

- Atmospheric fluid-bed combustors (AFBCs). AFBCs can use virtually any quality coal to produce electricity and process steam cleanly and efficiently. The coal can be fed with minimal preparation. The coal feed can be supplemented with waste materials. $\mathrm{AFBCs}$ are currently commercial in larger sizes. Small-size AFBCs are in the demonstration stage to prove their 
cost-effectiveness in these applications.

- Diesel engines fueled by coal-water fuel (CWF). Diesel engines fueled with CWF are entering the demonstration stage. A hot-water-drying process to produce CWF is being explored. Diesel engines with back- end emission control have less than $1 / 10$ of the $\mathrm{NO}_{\mathrm{z}}$ emissions of uncontrolled engines operating on diesel oil. Diesels can provide hot water or steam for heating or other uses. The sponsors of a DOE clean coal technology project funded to demonstrate a CWF diesel are reviewing the opportunity to transfer the project to Alaska.

These fossil-based systems could be used in hybrid systems that also incorporate renewable energy technologies, such as wind turbines, photovoltaic cells, or storage batteries. These renewable systems are being developed by DOE's Office of Energy Efficiency and Renewable Energy (EERE). Hybrid systems would provide reliable operation independent of wind or sunlight conditions.

5. Provide a Mechanism to Help U.S. Technology Vendors Market Their Technologies in Developing Countries Throughout the World

Alaska is representative of many developing countries in that it has a large number of remote communities that do not have developed transportation systems (other than air) or electrical transmission systems connecting communities. The lack of roads or rail, and seasonally limited water transport, makes it expensive to transport bulk commodities such as fuel. The remoteness also makes field fabrication of power systems very expensive. Without a transmission system in place, small, dispersed power generation systems capable of operating on local fuels are frequently the most economic option.

The knowledge base that U.S. equipment vendors develop by supplying small systems to Alaska is applicable to many developing countries. Thus business information being developed as part of projects implemented in Alaska will create business opportunities for U.S. equipment and technology in the international market.

\section{WHAT HAS METC-EERC DONE SO FAR?}

METC/EERC has been serving as a catalyst for this Initiative by providing information on small power systems to Alaskan native corporations and by networking U.S. vendors of small power generation technologies with these potential users in Alaska. Specific activities include the following:

\section{Alaskan Driver}

Over the past 4 years, METC has been conducting both joint and individual indepth discussions with representatives from the Alaskan native corporations and from the Alaskan state government. METC continues to provide both groups with information they require to make decisions on what technological solutions best meet the needs of Alaskan residents.

\section{Workshop}

METC cohosted a workshop sponsored by the State of Alaska Department of 
Community and Regional Affairs (DCRA) in Anchorage on May 17-18, 1994. The purpose of the workshop was to introduce alternative power systems to Alaska and to educate vendors of power systems about Alaskan issues. Over 130 people attended the workshop, including representatives from 20 different U.S. technology vendors and 53 representatives from Alaskan native corporations, village utilities, or Alaskan governmental agencies. The proceedings from the workshop are available.

A second workshop sponsored by the EERC, is planned for September 25-26, 1995. This workshop will showcase the Alaskan Initiative to transfer the technologies to other Native American groups.

3. Cooperative Research and Development Agreements (CRADAs)

METC has signed CRADAs with the Alaskan Department of Community and Regional Affairs (DCRA) and with the Doyon Native Corporation. The primary purpose of these CRADAs is to conduct screening studies and more detailed feasibility studies of specific small power systems in Alaskan villages.

\section{Assessments}

As part of the Alaskan CRADAs, METC-EERC and their CRADA partners are conducting (or will conduct) assessments for the installation of emerging power systems at several Alaskan locations, including Tok and McGrath.

5. Team Building
METC-EERC have been actively developing teaming arrangements for possible demonstration projects in Alaska. Discussions have included all members of a vertical integration energy supply team including native corporations, state and federal agencies, well drillers, coal mine owners, utility operators, and equipment vendors.

\section{Coal Testing}

In support of the CRADA-associated systems studies discussed above, the University of Alaska has conducted lab-scale testing of a potential coal feedstock for a proposed atmospheric fluidized-bed combustion (AFBC) system for the village of McGrath. The University is testing Little Tonzona coal. Donlee Technologies is testing 30,000 lb of this coal in its AFBC pilot plant in Pennsylvania.

\section{Cooperation with EERE}

METC is closely cooperating with EERE on this Initiative. In FY94, METC assisted EERE in reviewing the proposals it received in response to a request for proposals to develop. integrated energy systems on Native American lands under Article XXVI of the 1992 Energy Policy Act. At METC's invitation, DOE EERE participated in the Alaskan workshop.

8. Support Tasks with the EERC

The FY95 Interior Appropriation provided $\$ 600 \mathrm{~K}$ for EERC to support METC Alaskan activities. As part of this activity, the EERC:

- Provided support for the May 1994 workshop held in Anchorage. 
- Obtained cost-share funding from an Alaskan Consortium to study the feasibility of building a plant to produce a low-rank coal-water fuel (LRCWF) in Alaska. Usibelli coal will likely be used for the project. The Consortium has identified a site at the University of Alaska-Fairbanks, as the likely location for the project.

- Is conducting studies to determine the market potential for CWF both in Alaska and in the export market.

- Is working with METC to finalize indepth assessments of villages considering advanced power systems.

9. College of West Virginia

Under its multistrata completion contract with METC, the College of West Virginia has reviewed existing coalfield data and plans to drill one or two wells at Chignik Lagoon to produce coal-bed methane which will be fed to a fuel cell to produce electricity and heat for local use.

\section{WHAT'S NEXT?}

METC proposes to support several near-term demonstrations to introduce emerging power generation technologies to rural Alaskan villages. Under the leadership of the EERC, METC will work with entities in Alaska and elsewhere to support the demonstration of the following technologies:

- A 200-kW phosphoric acid fuel cell (PAFC) operating on coal-bed methane in the Chignik region. Natural gas-based fuel cell projects are also being explored.
An atmospheric fluid-bed combustion (AFBC) system fueled by coal at McGrath and/or Tok based on guidance from Doyon, Ltd., and the state of Alaska.

A diesel engine fueled by coal-water fuel (CWF) funded under the Clean Coal Technology Demonstration Program.

\section{PAFC DEMONSTRATION}

A demonstration of a 200-kW PAFC operating on coal-bed methane is being planned by the College of West Virginia at the village of Chignik Lagoon. The project will involve an Alaskan drilling firm and will be conducted in cooperation with the Chignik Lagoon Regional Corporation, the Bristol Bay Native Corporation, the Chignik Lagoon Tribal Council, International Fuel Cells Corporation and the Department of Energy.

In 1994 and 1995, METC provided funds to the College of West Virginia to conduct studies at five Alaskan remote Native American (including Native Alaskan and Eskimo) sites to determine the feasibility of producing enough methane from coal seams to feed a $200-\mathrm{kW}$ fuel cell. Based. upon the information derived, the College of West Virginia, in cooperation with Native American and Alaskan authorities, was requested to select one of the five sites for the conduct of a demonstration. As a result of this effort, Chignik Lagoon was selected as the most promising site.

Plans call for the College of West Virginia to lead the effort to drill two production wells at Chignik Lagoon and couple the methane produced to a fuel cell to produce clean, efficient, and competitively priced electricity to the village. The project will also create jobs for local 
Native Americans in the village. If successful, the technology could be deployed throughout other remote regions in Alaska, other parts of the United States, and in foreign countries.

The estimated cost for the project is $\$ 2.05$ Million. This estimate includes drilling and completing the wells and putting them into production, purchasing and installing the fuel cells and integrating the unit operations into the local transmission and distribution system. Funds for the integrated project will come from funds already appropriated to the College of West Virginia by METC, additional funds expected from Alaskan sources, financing of some elements of the project, and the FY95 fuel cell "buy-down" program directed by METC.

Electricity could be produced from the project as early as late 1995.

Other related programs in Alaska are aimed at assessing the opportunities to demonstrate PAFCs in locations where natural gas is available or can be costeffectively obtained. One such project is being pursued at the National Guard Armory at Fort Richardson in Anchorage. Here, the fuel cell "buy-down" program

- being administered by METC is being discussed as the mechanism to purchase one of two PAFCs using natural gas already supplied to the site.

\section{AFBC SYSTEM DEMONSTRATION}

The economic feasibility of demonstrating AFBC at specific village sites is currently being examined by METC-EERC for its their CRADA partners. Under the CRADA with the Doyon Corporation, a feasibility study of an AFBC at the village of McGrath will be completed in August 95. The AFBC would cofire Little
Tonzona coal and possibly village wastes. Plans call for McGrath Power \& Light to build a $1-\mathrm{MWe}$ AFBC plant to produce electricity to displace much of its current high-cost diesel fuel-based capacity.

The utilization of waste heat from the plant is also being studied. The plant and coal facilities will use local labor.

A conceptual design of the AFBC plant is currently being developed to a sufficient level of accuracy to allow bank financing of the project. To support the design activities, 30,000 pounds of Little Tonzona coal and limestone was mined by Doyon and shipped to Donlee Technology, a Pennsylvania boiler manufacturer, where it was test-burned in a pilot AFBC. A decision by Doyon on whether to proceed with the project is expected by the fall of 1995.

Under the DCRA CRADA, DCRA and METC selected the villages of Tok and Tanana as two probable locations for an AFBC demonstration. This selection was based on input from the Anchorage workshop. A 2.5-MWe project at Tok has higher priority because of the active interest being shown by the local utility Alaska Power \& Telephone (AP\&T) and because of the announced closing of the local landfill. The project would use Jarvis Creek coal which has been leased by AD\&TR from the Alaska Department of Natural Resources. In addition, locally produced municipal solid waste would be cofired in the combustor. The new plant would be used to meet increasing electricity demand, replace some of the existing and high diesel fuel-fired capacity, and produce heat which would be used in several commercial buildings now dependent upon diesel fuel. A feasibility study for the project is expected to be completed in December of 1995. 
Both projects could be used as stepping stones to the utilization of this clean, efficient and economically competitive technology in other remote locations throughout Alaska and the rest of the world.

\section{DEMONSTRATION OF DIESEL ENGINES FUELED BY COAL-WATER FUEL}

METC-EERC, with their CRADA partners, are investigating the feasibility of a project to demonstrate the operation of a coal-fueled 5-MW diesel. CooperBessemer has developed this technology for small power plants (1-50 MW) and it appears ideal for Alaskan communities with high delivered-oil prices and access to a coal-water fuel (CWF) production facility.

A clean coal demonstration project has already been funded to demonstrate this technology. This project could be located at the University of Alaska-Fairbanks with the planned Alaskan Consortium project to build a low-rank coal-water fuel (LRCWF) production plant. Some of the fuel produced at the LRCWF facility would be fed to the coal-fired diesel to produce heat and electricity to meet energy growth in the region and to reduce dependence upon diesel fuel. CooperBessemer's standard CWF supplier (Coal Quality, Inc.) would work with the Consortium to optimize the approach for producing engine-grade $C W F$ in Alaska. The estimated cost of a 5-MW, 3-year demonstration project integrated with the LRCWF demonstration is approximately $\$ 40$ million, half of which will be provided by METC.

\section{AUTHORIZATION FOR THE ALASKAN INITIATIVE}

METC's Alaskan Initiative is being conducted under the broad auspices of Title XXVI, Indian Energy Resources, of the Energy Policy Act of 1992 . Section 2603 of this Title provides that "the Secretary of Energy in consultation with the Secretary of the Interior shall establish and implement a demonstration program to assist Indian tribes in pursuing energy self-sufficiency and to promote the development of a vertically integrated energy industry or Indian tribe,... including any Alaska native American village or regional or village corporation as defined in or established pursuant to the Alaska Native Claims Settlement Act."

\section{CONCLUSION}

METC and EERC are in the early stages of implementing an Initiative in cooperation with Alaskan interests to demonstrate emerging energy systems in rural villages in Alaska. The benefits of this Initiative are as follows:

- Affordable emerging energy systems being made available to the over 120 remote villages in Alaska.

- Low-emission systems that can contribute toward integrated solutions to current environmental problems.

- Local job creation in Alaskan villages.

- Demonstration of capability and versatility of coal-fired or natural gasfired emerging energy systems.

- Provision of a mechanism to help U.S. technology vendors market their technologies in developing countries throughout the world. 
It is envisioned that several demonstration projects of emerging technologies driven by Alaskan interests will be conducted under this initiative. Title XXVI, Indian Energy Resources, of the Energy Policy Act of 1992, authorizes these types of projects. METC and the EERC are establishing teaming arrangements with groups that are in a position to help implement such demonstrations. Those groups include Doyon, Ltd., and other native corporations, local Native American communities, the Alaskan Department of Community and Regional Affairs, the College of West Virginia, the University of Alaska, other state and federal agencies, well drillers, coal mine owners, utility operators, and equipment vendors. These organizations have the capability to establish "virtual corporations" to conduct demonstfation projects in Alaska and to provide most of the required funding. Because of its intimate knowledge of small power generation technologies, the METC-EERC team are in the ideal position to catalyze this activity. 